NBER WORKING PAPER SERIES

LONG-TERM ORIENTATION AND EDUCATIONAL PERFORMANCE

\author{
David Figlio \\ Paola Giuliano \\ Umut Özek \\ Paola Sapienza \\ Working Paper 22541 \\ http://www.nber.org/papers/w22541
NATIONAL BUREAU OF ECONOMIC RESEARCH
1050 Massachusetts Avenue
Cambridge, MA 02138
August 2016

\begin{abstract}
We thank participants at Bocconi University, Catholic University of the Sacred Hearth (Milan), Erasmus University, European Association of Labor Economists, Family and Education Workshop, Federal Reserve Bank of New York, IZA, Gerzensee Summer Symposium 2015, Harvard-MIT Positive Political Economy Seminar, Long Run Factors in Comparative Development conference, New York University, Nordic Summer Institute in Labor Economics, OECD, University of British Columbia, University of Calgary, University of Colorado, University of Warwick, University of Zurich and the Warwick summer Workshop in Economic Growth for comments that substantially improved the papers. We also thank Gaia Dossi and Riccardo Marchingiglio for extraordinary research assistantship. We appreciate the financial support from the National Institutes of Child Health and Human Development (Figlio), National Science Foundation (Figlio), and US Department of Education (Figlio and Özek). We are especially grateful to the Florida Department of Education and Health for providing the linked population-level administrative data that permitted this analysis to take place. All errors and opinions are those of the authors and do not reflect those of the funders or the Florida Departments of Education and Health. The views expressed herein are those of the authors and do not necessarily reflect the views of the National Bureau of Economic Research.
\end{abstract}

NBER working papers are circulated for discussion and comment purposes. They have not been peer-reviewed or been subject to the review by the NBER Board of Directors that accompanies official NBER publications.

(C) 2016 by David Figlio, Paola Giuliano, Umut Özek, and Paola Sapienza. All rights reserved. Short sections of text, not to exceed two paragraphs, may be quoted without explicit permission provided that full credit, including $\odot$ notice, is given to the source. 
Long-Term Orientation and Educational Performance

David Figlio, Paola Giuliano, Umut Özek, and Paola Sapienza

NBER Working Paper No. 22541

August 2016

JEL No. I20,I24,J15,Z1

\begin{abstract}
We use remarkable population-level administrative education and birth records from Florida to study the role of Long-Term Orientation on the educational attainment of immigrant students living in the US. Controlling for the quality of schools and individual characteristics, students from countries with long term oriented attitudes perform better than students from cultures that do not emphasize the importance of delayed gratification. These students perform better in third grade reading and math tests, have larger test score gains over time, have fewer absences and disciplinary incidents, are less likely to repeat grades, and are more likely to graduate from high school in four years. Also, they are more likely to enroll in advanced high school courses, especially in scientific subjects. Parents from long term oriented cultures are more likely to secure better educational opportunities for their children. A larger fraction of immigrants speaking the same language in the school amplifies the effect of Long-Term Orientation on educational performance. We validate these results using a sample of immigrant students living in 37 different countries.

David Figlio

Institute for Policy Research

Northwestern University

2040 Sheridan Road

Evanston, IL 60208

and NBER

figlio@northwestern.edu

Paola Giuliano

Anderson School of Management

UCLA

110 Westwood Plaza

C517 Entrepreneurs Hall

Los Angeles, CA 90095-1481

and IZA

and also NBER

paola.giuliano@anderson.ucla.edu

Umut Özek

American Institutes for Research/CALDER 1000 Thomas Jefferson St. NW

Washington, DC 20007

uozek@air.org

Paola Sapienza

Kellogg School of Management

Northwestern University

2001 Sheridan Road

Evanston, IL 60208

and CEPR

and also NBER

paola-sapienza@northwestern.edu
\end{abstract}




\section{Introduction}

Several papers find a remarkable correlation between individual educational achievement and family socioeconomic background in the US and around the world (see, e.g., Black, Devereux, and Salvanes, 2005; Chevalier, Denny, and McMahon, 2009; Fryer and Levitt, 2004; Hanushek and Woessmann, 2010; Hertz et al, 2007; Reardon and Galindo, 2009; and Rothstein and Wozny, 2013). To understand the strong persistence in educational achievement across generations, several economists have tried to examine the direct effect on education of some specific components of parental socioeconomic background: parental education, income, and wealth. ${ }^{2}$ This research has found at most moderately-sized (and often zero) causal effects, suggesting that much of the correlation between parents' and children's educational outcomes must be due to other family characteristics, including access to high quality schools (Rouse and Barrow, 2006), or inherited abilities and traits (Krapohl et al., 2014).

Parents transmit to their children not only human capital, income, wealth, and genetic traits but also a specific set of cultural values (Bisin and Verdier, 2001). This paper follows the literature on cultural transmission and explores the importance of a distinct cultural trait transmitted from parents to children as an alternative and complementary source of persistence in educational outcomes across generations. Research in psychology suggests that the ability to defer gratification and to exert selfcontrol fosters educational attainment and cognitive competence (Mischel and Ebbese, 1970; Mischel et al., 1988; Mischel et al., 1989; Shoda et al., 1990). In a recent paper, Galor and Ozak (2016) show a remarkable persistence over time of preferences for delayed gratification and trace their origin to geographical conditions that affected the return to agricultural investment. Furthermore, Galor and Ozak (2016) show that, across geographical areas, preferences for delayed gratification correlate, not only with education, but also with technology adoption and savings. Given that time preferences and delayed gratification correlate with educational attainment at the macro level, in this paper we study whether the transmission of these preferences across generations can explain individual educational attainment and possibly account for the intergenerational persistence observed in the literature.

To investigate this hypothesis, we face several challenges. First, if parents share a culture of high educational attainment, they are likely to be highly educated and, thus, more likely to have high

\footnotetext{
${ }^{2}$ For example, Black, Devereux, and Salvanes (2005) study the effect of an exogenous mandatory change in parental education on their children educational outcomes and cognitive abilities. Similarly, Dahl and Lochner (2012) study the effect of exogenous changes in parental income while Bleakley and Ferrie (2016) investigate the effect of an exogenous change in wealth.
} 
income and live in areas with better schools, therefore hindering our ability to distinguish between a transmission of cultural values and a direct effect of parental education or income. Second, cultural determinants of educational attainment cannot be distinguished from other institutional and economic factors using cross-country aggregate data. For example, a culture that values delayed gratification could foster high quality of schools and other educational institutions. If that is the case, we would not be able to distinguish whether the effect of higher education attainment is due to better institutions or to children's attitudes of delayed gratification.

To address these concerns we focus on immigrants in the US and in other countries. We link immigrants to their country of origin cultural measure of the willingness to forego immediate utility for future gratification. Studying immigrants yields several key advantages. First, before fully assimilating, immigrants are more likely to maintain a strong connection with the culture of their country of origin. Second, many immigrants often fall in the lowest range of the income distribution and do not come from privileged backgrounds compared to other residents of their new countries. As such, they share schools with students of similar socioeconomic background, making it easier to separate the effects of culture from other school characteristics and parental socioeconomic background. Following Fernandez and Fogli (2009) and Giuliano (2007), our identification strategy relies on the opportunity to observe immigrant children from different cultures in the same location (same school), thus distinguishing between the cultural factors from other institutional and economic factors. However, this is the first paper that studies cultural transmission by focusing on children's outcomes, thus allowing us to understand the role of parenting in the transmission of culture. Other papers in this literature observe immigrants when they are already young adults, therefore making it harder to understand the channels of cultural transmission.

We study immigrants' educational outcomes in a unique population-level dataset that contain individual-level administrative data from the Florida Department of Education (FLDOE) Warehouse on K-12 students, matched to birth certificate data from the Florida Bureau of Vital Statistics for the purposes of this research agenda. This dataset presents numerous advantages. First, this paper presents the first use of administrative data to study the relevance of cultural traits in explaining educational outcomes of first and second-generation immigrants. Florida is one of the largest immigrant-receiving states in the United States ${ }^{3}$ and the FLDOE data allow us to observe the entire population of public

\footnotetext{
${ }^{3}$ Florida has over four million foreign-born individuals, more than all but 15 entire countries on earth. Florida's foreign-born population is also diverse: While the foreign-born population is disproportionately Hispanic (include 23\% Cuban and 7\% Mexican), it is also 21\% from non-Hispanic Caribbean countries, 11\% from Asian
} 
school students, and to control for school fixed effects and several socioeconomic characteristics. The link to birth records allows us to identify second generation students and also to control (in the case of Florida-born children) for variables not typically observed in administrative education data such as maternal age, marital status, and education, birth order, and the like. The richness of the dataset also allows us to follow students at a level of disaggregation finer than a neighborhood (the school of attendance), therefore improving on the existing literature, which at most compares outcomes of migrants in similar MSAs. Second, we are able to follow these students over time during their primary education years, measuring not only their educational achievement at one point in time, but also the change over time. The longitudinal nature of the dataset is also an improvement compared to other studies of culture, which only present cross-sectional analysis. Point-in-time comparisons can conflate cultural transmission with unmeasured shared correlates between parents and children, but longitudinal data permit the opportunity to explore both levels and trajectories of outcomes. Furthermore, the ability to study both first generation and second generation immigrants permits us to pin down more confidently the degree to which it is the parents' country of residence where they grew up, rather than the student's country of residence, that is influential.

To study the importance of delayed gratification, we link each student within subgroups of interest (based either on country of origin or language spoken at home) to a measure of Long-Term Orientation developed by Hofstede et al. (2010). Hofstede et al. (2010) define Long-Term Orientation as the cultural value that "stands for the fostering of virtues oriented toward future rewards." Controlling for school and year fixed effects, as well as individual characteristics and measures of family income, we correlate the performance of first and second generation immigrant students to the Long-Term Orientation of their countries of origin. The results show that immigrants from countries with high Long-Term Orientation not only score substantially higher in standardized tests than immigrants originating from countries with lower Long-Term Orientation, but, over time, their scores in mathematics and reading grow more, controlling for their initial third grade score, suggesting that, in comparison with low Long-Term Orientation students, these immigrants not only have higher educational achievement in third grade but also continue to improve in relative terms over time. This is noteworthy because it is unusual for students to make large changes in their relative positions between the third and eighth grades, but the higher the measure of Long-Term Orientation, the more

countries, 10\% from European countries, and 2\% from African countries. The heterogeneity in countries of origin of foreign-born residents of Florida is dramatically greater than in Texas and California, where the majority of foreign-born residents come from a single country, Mexico. 
likely this is to happen. Similarly, we find that immigrants from long term oriented countries have better school attendance records, are less likely to repeat a grade and to be truant, and are more likely to graduate in four years. Students from more long term oriented countries are also more likely to enroll in advanced college level classes (AP, IB, and AICE classes) during high school and more likely to choose advanced classes in scientific subjects. Given that we control for school-by-year fixed effects in all our specifications, our results are not driven by school quality, a potential source of selection for immigrants coming from long term oriented cultures. They are also robust to including several measures that control for potential confounding characteristics of the country of origin, including, for instance, differential educational selection of immigrants, economic conditions of the country of origin, and international test scores of the country of origin, as well as several maternal characteristics. Also, our results are not driven by specific groups of immigrants; importantly, we can rule out the possibility that our results are merely comparisons of immigrants from one part of the world (e.g., Asia) versus those from another part of the world (e.g., Latin America). The findings are also confirmed when we use two alternative measures of time preferences.

The theoretical literature on intergenerational transmission of preferences (Bisin and Verdier, 2000, 2001; Doepke and Zilibotti, 2008, 2015) suggest that economic conditions and altruistic motives induce parents into teaching specific preferences to their children. Our results are consistent with this view and suggest that, especially in the context of Galor and Ozak (2016), parents from certain regions are more likely to teach values of patience and Long-Term orientation. ${ }^{4}$ The effects of Long-Term Orientation on educational attainment could potentially be driven by two complementary mechanisms. On the one hand, the offspring of more long-term oriented parents may be taught a culture that value working harder and studying harder to achieve long term goals. On the other hand, parents with a higher Long-Term Orientation may exert higher effort in securing good education opportunities for their children by prioritizing their kids' education over other personal goals. In turn, children may better absorb the values shared by their parents when they observe them prioritizing education.

To gain further insights on how the transmission of this cultural value impacts performance we study some of these potential mechanisms. While we cannot directly measure the transmission of values from parents to children, nor measure students' effort, we can test whether parents originating from countries that share values of delayed gratification take actions that increase the educational

\footnotetext{
${ }^{4}$ Alternatively, persistent behavior over time may be due to the transmission of beliefs (Guiso et al, 2008). Parents may teach the belief that sacrificing immediate reward for future reward brings long term benefits.
} 
attainment of their children. We study whether these parents are more likely to select better schools within the school district of residence ${ }^{5}$ and whether they are more likely to advocate for their children's inclusion in gifted programs, conditional on the student's achievement. We find evidence consistent with the hypothesis that parents from countries with higher Long-Term orientation are more likely to select good educational opportunities for their children. This mechanism can increase educational outcomes and increase the direct effect of transmitting values of delayed gratification to their children. As an additional channel of cultural transmission we study whether social learning (Boyd et al., 2011) reinforces the importance of the cultural values transmitted at home. Consistent with a social learning story, we find that the fraction of children speaking the same language in school indeed magnifies the effect of Long-Term Orientation on educational performance.

While our data are unique as they allow us to follow immigrant students over time, we face the potential criticism that the self-selection of immigrants in Florida can be accounting for the results. For this reason, we repeat our analysis using a large set of countries from the Programme of International Student Assessment (PISA) absorbing the country of destination fixed effect. We find a remarkable qualitative and quantitative similarity with this very different sample of immigrants suggesting that independently of the formal institutions of the country of destination, the relative performance of immigrants is related to the Long-Term Orientation of the country of origin, thereby indicating that our results have a reasonably high degree of external validity.

Our results suggest the existence of a cultural channel that explains the persistence of educational outcomes across generations, beyond income and educational transmission. Besides being related to a fast growing literature on cultural transmission (Alesina et al., 2013; Alesina and Giuliano, 2015; Algan and Cahuc, 2010; Becker et al., 2016: Galor and Moav, 2002; Galor and Michalopoulos, 2012; Guiso et al., 2006; Nunn and Wantchekon, 2011; Sacerdote, 2005; Tabellini, 2008; Voigtlander and Voth, 2012), our paper relates to the intergenerational mobility literature and to the research on immigrants' assimilation. Chetty and Hendren (2015) find that local conditions matter less for immigrants consistently with the conjecture that culture, rather than neighborhood's characteristics, can play an important role for immigrants. The literature on immigrants has systematically identified an "advantage" of some immigrant groups but, as far as we know, no paper has identified which

\footnotetext{
${ }^{5}$ Note that our analysis of student outcomes includes school-by-year fixed effects, so this differential school choice associated with Long-Term Orientation is not the factor that drives the student outcomes results that we describe in the paper.
} 
cultural factors may be responsible for these findings (Card et al., 2000; Abramitzky, Boustan, and Eriksson, 2014).

The remainder of the paper is organized as follows. The next section describes the main

dataset. Section 2 presents the empirical evidence from the FLDOE data. The results using PISA are presented in Section 3. We conclude in Section 4.

\section{Data and outcome of interests}

The main data sources for our analysis are school records obtained from the Florida Department of Education Data Warehouse, and the measure of Long-Term Orientation at the country level based on Hofstede (2010). For external validity we rely on student level data coming from the Program for International Student Assessment (PISA), described in Section 3.

\subsection{Florida Department of Education Data}

We use a unique dataset of school records for the state of Florida merged with birth certificates coming from the Florida Bureau of Vital Statistics.

The individual-level administrative data from the Florida Department of Education (FLDOE) Warehouse contains information on K-12 students who attended Florida public schools between 2002-2003 and 2011-2012. The dataset also contains information about the country of origin of the child and the language spoken at home. The dataset is longitudinal in nature, therefore it allows us to follow students over a decade and study their progress within subgroups of interest (either country of origin or language spoken at home).

Birth certificates contain a larger set of socio-economic controls (such as maternal education, marital status and age of the mother), normally not included in school records. They also contain information on whether the mother was born abroad. Birth certificates and school records were matched using first and last names, date of birth and social security numbers. ${ }^{6}$ Since data from birth certificates are available only for children born between 1992 and 2002, we limit our analysis to these cohorts for all immigrants groups (including the first generation for which the birth certificates are not present). The FLDOE dataset merged with birth certificates allows us to study educational outcomes for first, second and higher than second generation immigrants. To identify the different

\footnotetext{
${ }^{6}$ The sample of birth records consists of 2,047,633 observations. Of these, 1,652,333 were present in Florida public school data. The match rate of $81 \%$ is consistent with the percentage of children who are born in Florida, reside there until school age, and attend public school, as calculated from the Census and the American Community survey for the corresponding years. See Figlio et al. (2014) for details about the nature and additional evidence on the quality of the birth-school data merge.
} 
generations, we use information about the country of origin of the child, whether the mother was born $\mathrm{abroad}^{7}$, and the language spoken at home.

We identify first generation immigrants using a question present in the FLDOE on the country of birth of the child. We also use a more restricted definition of first generation immigrants, which combines the information regarding the country of birth and the language spoken at home. Using the restricted version, we define as first generation a child born in country A, who also speaks at home one of the main languages spoken in that specific country. ${ }^{8}$ This restriction can reduce some measurement error coming from those cases in which a child is born abroad but he/she is from the United States (for example children born in a US military base) or it could also capture a stronger cultural attachment as it reflects the intention of the family to speak their own language at home to preserve their cultural identity.

We identify two groups of second generation immigrants. As a first group, we define a maternal second generation immigrant as a child who was born in the US but whose mother was born abroad. Birth certificates do not contain information about the maternal foreign country of birth (with the exception of the following countries/territories: Canada, Cuba, Guam, Mexico, Puerto Rico, and Virgin Islands); they only indicate whether the mother was born abroad or not. For that reason, we identify the second generation using the three countries identified in the birth certificate for which we have the Long-Term Orientation data (Canada, Mexico, and Puerto Rico) and the language spoken at home for all the remaining cases. ${ }^{9}$ We also use an alternative definition of second generation students by adding all children born in the US, speaking a language different than English at home, and whose maternal place of birth is either the US or unknown. This group could potentially include a generation higher than the second, but also second generation immigrants from the paternal side ${ }^{10}$ (children with fathers born abroad and mothers born in the United States). We called this group "extended second generation."

\footnotetext{
7 The birth record data provided by the Florida Bureau of Vital Statistics does not include information on father's place of birth.

8 The list of the main languages spoken in a country is taken from the $17^{\text {th }}$ version of the Ethnologue.

9 Therefore, for the second generation, we have difficulty differentiating among the approximately $15 \%$ of second generation immigrants who are Spanish-speaking but whose mothers were not born in one of the specified locations. We carry out all analyses both with and without Spanish speakers and demonstrate that this is not driving our findings in any meaningful way.

${ }^{10}$ We cannot identify this group from birth certificates as we have only information regarding maternal country of birth.
} 
The total sample of student records (immigrants and non-immigrants) consists of $18,734,847$ student-year observations. The initial sample of unique individual students for the 1992-2002 cohorts observed during the period between the 2002-2012 school years consists of 3,018,961 students. The sample of first generation immigrants consists of 354,954 unique individual students. The sample of second generation immigrants (the restricted version) consists of 396,330 unique students identified based on the foreign-born status of the mother. For our extended definition of second generation students we include additional 269,487 unique students, identified using the language spoken at home. The sample of natives (individuals born in the US, whose mothers were born in the US and who speak English at home) consist of 1,959,058 unique students. ${ }^{11}$

For the first generation, we merge the country of origin with the Long-Term Orientation variable defined at the country level. We have information on Long-Term Orientation for 93 different countries. (The list of countries and the number of observations by country is provided in the Appendix, Table A1, for both the unrestricted and restricted definition).

For the groups of immigrants identified through language (second generation) we construct a measure of Long-Term Orientation at the language level. For most languages there is a one to one association between language and country of origin (for example Norwegian). For languages spoken in multiple countries (for example Portuguese) we calculate the Long-Term Orientation cultural variable as a weighted average of the Long-Term Orientation of all the countries in which Portuguese is the main language spoken in the country. We use as weights the fraction of first generation immigrants in our sample speaking that language and born in a country where that language is one of the spoken languages. For instance, in the case of Portuguese, we allocate $98 \%$ of the weight to Brazil and $2 \%$ of the weight to Portugal, in accordance with their shares of language-speakers in the Florida school data. ${ }^{12}$

The number of observations by language for the second generation from the maternal side and for extended definition of children of immigrants are presented in Table A2 of the On-line Appendix. We have information on 93 different languages.

\footnotetext{
${ }^{11}$ We also consider as natives, children speaking English at home, born in the US but outside Florida and for whom the place of birth of the mother is unknown (if a child is born outside Florida, the birth certificate is not available). We drop from the sample 39,132 unique students for whom the language and the country of origin of the child are missing and/or were born in Florida but the mother birthplace is labeled as "missing" in the birth records.

12 As a robustness check, we also run our regressions limiting the sample to countries which can be uniquely identified with a language. Our results (available from the authors) are robust to this specification.
} 


\subsubsection{Comparison between natives and immigrants}

Florida is one of the top immigrant states in the United States, both in terms of numbers of immigrants and immigrant share of the total population. Given that our data only includes students in public schools, it is important to compare the characteristics of first and second generation immigrants going to public schools with those of the natives. ${ }^{13}$ The descriptive statistics for the three groups based on Census 2000 and 2010 are shown in the on-line Appendix (Table A3). In 2000, the fraction of natives and second generation immigrants going to public schools is very similar $(88 \%$ of natives and $87 \%$ of second generation), while the number is slightly higher for the first generation $(93 \%) .{ }^{14}$ Similarly, the family income of natives and second generation immigrants does not differ substantially in 2000 (around \$61,000), whereas the average income is lower for the first generation $(\$ 46,441)$. Furthermore, when we restrict the sample to families sending their children to public schools, the income is lower than the income of families with children in private schools, as expected, but the differences between groups is again similar for natives and second generation immigrants ( $\$ 55,838$ and $\$ 52,842$, respectively) and lower for first generation immigrants $(\$ 43,526) .{ }^{15}$ The patterns are similar for 2010.

\subsubsection{Outcomes of interest}

We study the following five different outcomes, separately for our first generation, second generation and extended second generation samples:

i) Test scores in mathematics and reading. Here, we look both at differences in the Florida Comprehensive Assessment Test (FCAT), the state's high-stakes criterion-referenced test, in grade 3 (the first grade of statewide testing) as well as the increase in performance from grade 3 to grade 8 , after controlling for the initial score reported in grade 3. Studying test score growth is especially important because test score levels might reflect some omitted variable correlated with Long-Term Orientation, but it is very rare for students to dramatically change their relative position in the statewide test score distribution between grades 3 and 8. Because the test changed in 2011 and to aid in interpretation, we standardize the statewide test scores to zero mean and unit

\footnotetext{
${ }^{13}$ When we look at the Census, we define second-generation immigrants as children born in the US with at least one parent born abroad.

${ }^{14}$ The numbers are very similar in the Census 2010: 88\% of native and second generation immigrants, and $93 \%$ of first generation immigrants, attend public schools.

15 The differences across groups in the Census 2010 are similar.
} 
variance at the grade/year level based on the sub-sample used in the regression/specification.

ii) Probability of being retained, defined as a dummy equal to one if the student repeats the same grade at least once. Retention is calculated for all grades from 3 to $12 .{ }^{16}$

iii) Absence rates during academic year defined as the percentage of days in which the student is absent during the academic year. Absence rates are calculated for all grades from 3 to 12 .

iv) Disciplinary incidents: a dummy for whether the student was involved in a disciplinary incident (serious offences often resulting in suspension). Disciplinary incidents are calculated from grades 6 to 12, as incidents are extremely rare in elementary school.

v) High school graduation: a dummy for whether the student received a standard diploma within four years after entering the $9^{\text {th }}$ grade for the first time. This part of the analysis is conducted only for those students who have the potential to be observed for at least four years after they start high school, so we can only study this outcome for the oldest students in our population.

In addition, in the section devoted to understand the potential mechanisms linking Long-Term Orientation and educational attainment, we study four additional outcomes:

vi) Enrollment in advanced classes: we calculate the fraction of advanced classes, including Advanced Placement (AP), International Baccalaureate (IB), and Advanced International Certificate of Education (AICE), over the total of all classes taken by the student in a given year, for grades 9 to $12^{17}$.

${ }^{16}$ In Florida there is a mandated third-grade retention for all students who do not meet a Level 2 benchmark or higher (the second lowest of five levels) on the Florida Comprehensive Assessment Test (FCAT) reading exam, though some exceptions to this rule are admitted (LiCalsi, Özek, and Figlio, 2016). LiCalsi, Özek, and Figlio (2016) find that family factors are important determinants of differential enforcement of the mandatory retention rule, and that children from high-SES families are comparatively more likely to be promoted despite the mandatory retention rule, indicating some room for parental influence in school decision-making, even in cases when decisions are putatively mandatory. Retention in subsequent grades is not based on a strict score cutoff. As such retention in third grade is substantially higher than in other grades. In our tables we will study the retention in every grade. In unreported regressions, we tested retention only in grade 3 and the effects are similar in magnitude.

17 These three possible types of advanced classes are offered in Florida public schools and are recognized as college level classes at least by state Universities. 
vii) Fraction of advanced classes in scientific subjects: we calculate the fraction of advanced classes in scientific subjects (defined as Math, Computer Science or Natural Sciences) over the total of advanced classes.

viii) School choice: the Florida Department of Education reports school scores on a letter scale from A (best) through F (worst) ${ }^{18}$. We study school choice by looking at the relationship between Long-Term Orientation and the score assigned to the school in the year before entering kindergarten (this is the first time in which the student enters the public school system). We also look at the relationship between Long-Term Orientation and school scores for all grades.

ix) Gifted students: Florida defines gifted students as "students who have superior intellectual development and are capable of high performance.” Each district serves gifted students with local plans and a specific track. Eligibility for the program is determined by the parents, the student when appropriate, the teacher, a school system representative, and an evaluation specialist. Family intervention is therefore very relevant to determine the enrollment in a gifted program. To study family intervention we restrict our sample to children who are top performers ${ }^{19}$ in grade 3 and not enrolled in a gifted program, and test whether the probability of being enrolled in a gifted program in grade 4 is correlated with Long-Term Orientation.

Sample statistics for all outcomes are described in Table 1 and more details about each variable are contained in the Online Appendix.

\subsubsection{Individual controls}

All our regressions contain a large set of controls, including demographics (age in months and gender), a measure of English proficiency (measured by a dummy equal to one if the student is enrolled in the limited English proficiency program), a measure of low-income status (measured by a dummy equal to one if the student is eligible to receive free or reduced free lunch or attend a "provision 2"

\footnotetext{
${ }^{18}$ For a description of the school grading process in Florida, see http://schoolgrades.fldoe.org/. We recoded the letter scores on a scale from 1 through 5 , where 1 corresponds to an "F" score and 5 corresponds to an "A" score. These scores are highly salient to households when making decisions regarding residential location (Figlio and Lucas, 2004) or voluntary donations to public schools (Figlio and Kenny, 2009).

19 These are students who reach the highest achievement level (that is, level 5) in either Math or Reading, and either level 4 or 5 in the other subject.
} 
school $)^{20}$ and a measure for whether the student has some special education needs. ${ }^{21}$ Because special education, family income, and limited English proficiency are all potential consequences of parental Long-Term Orientation, we investigate the degree to which our results are driven by the decision of whether or not to control for these variables, and we find that our results are highly robust to their inclusion or exclusion. In our main specifications, we control for these variables, as well as school-byyear fixed effects (themselves a partial control for family background possibly driven by Long-Term Orientation), in order to obtain a likely underestimate of the "true" effect of Long-Term Orientation.

For second generation immigrants (including the extended version) born in Florida we also have information on maternal characteristics (educational attainment ${ }^{22}$, marital status at time of birth and whether the mother had the child when she was younger than 16), the number of older siblings and the zip code of the home address at time of birth. Sample statistics for these controls are shown in Table 1 and more details about each variable are contained in the Online Appendix.

\subsection{Long-Term Orientation Data}

Hofstede et al. (2010) define Long-Term Orientation as the cultural value that "stands for the fostering of virtues oriented toward future rewards, perseverance and thrift". Hofstede (1991) based his original analysis on data gathered from interviews of IBM employees across the world. This original data was later expanded using the data from the Chinese Values Survey and from the World Values Survey ${ }^{23}$. The Long-Term Orientation measure varies between 0 (short-term orientation) and 1 (longterm orientation). Figure 1 shows the distribution of Long-Term Orientation around the world. There is substantial heterogeneity: in our sample, the country with lowest Long-Term Orientation is Puerto Rico (taking the value of 0 ), whereas the country with the highest score is South Korea (taking the value of 1). Most Asian and many European countries show high numbers, most African and Latin American countries belong to the lowest part of the distribution, and Canada and Northern European Countries tend to lie somewhere in between. However, even within regions of the world, there exists considerable variation in the Long-Term Orientation measure.

\footnotetext{
20 To qualify for free or reduced lunch, the family income has to be respectively below $185 \%$ and $130 \%$ of the federal income poverty. Provision 2 schools establish claiming percentages and serve all meals at no charge for a 4-year period. For details see http://www.fns.usda.gov/school-meals/provisions-1-2-and-3.

${ }^{21}$ Categories for special education include mentally handicapped, orthopedically, speech, language, or visually impaired, deaf or hard of hearing. It also includes students with emotional or behavioral disabilities, with autistic spectrum disorder and other forms of serious disabilities (such as students with traumatic brain injuries).

22 We define dummies for high school completion, some years of college, and four or more years of college. In the regressions the excluded group is given by high school dropout mothers.

${ }^{23}$ For details see http://www.geerthofstede.nl/vsm-08.
} 
Galor and Ozak (2016) explore the origins of the distribution of Long-Term Orientation across countries and establish empirically that pre-industrial agro-climatic characteristics conducive to higher return to agricultural investment were the main determinant of the distribution of Long-Term Orientation across societies. The authors estimate the potential (rather than actual) caloric yield per hectare per year, under low level of inputs and rain-fed agriculture capturing cultivation methods that characterized early stages of development, while removing potential concerns that caloric yields reflect endogenous choices that could be affected by Long-Term Orientation.

In Section 2.5 we use Galor and Ozak's measure of potential caloric suitability as the most exogenous proxy for Long-Term Orientation. We also test the robustness of our results to differences in linguistic structures (Chen, 2013) that also proxy for a different weight attributed to future versus present choices. ${ }^{24}$

\section{Evidence from Florida data}

Before starting our empirical analysis, we first examine whether there exist systematic differences between each educational outcome and Long-Term Orientation as measured in the country of origin or by language spoken at home in our sample of first and second generation immigrants in Florida.

These raw correlations are reported in Figures 2 and $3 .{ }^{25}$ For all the outcomes we find that the relationship is in the hypothesized direction. Coming from cultures that emphasize the importance of Long-Term Orientation is positively correlated with test scores, an improvement in educational performance over time and the probability of graduating on time; immigrants and children of immigrants coming from long-term oriented cultures are also less likely to be retained in school, be absent from school or have disciplinary problems. The figures also show that the relationship is not driven by a small number of countries.

These differences could be driven by individual characteristics, school characteristics or systematic differences across countries of origin. Our empirical analysis takes care of all the above mentioned concerns by estimating the following equation:

$$
Y_{i c}=\alpha L T O_{c}+\beta X_{i}+\theta X_{i t}+\gamma_{g}+\delta_{t}+\mu_{s}+\mu_{s} \cdot \delta_{t}+\varepsilon_{i c t}
$$

\footnotetext{
${ }^{24}$ Detailed information on Galor and Ozak (2016) and Chen (2013) measures are provided in Section 2.5.

${ }^{25}$ For purposes of confidentiality, we only show data points for countries of origin/languages where we observe at least 50 individuals. The statistical analyses that follow include all data, including those from countries of origin/language-speakers with fewer than 50 observations.
} 
where $Y_{i c}$ is an outcome of interest for student $i$ coming from country $c$, and $L T O_{c}$ is our measure of Long-Term Orientation measured at the country level or by language spoken at home. $X_{i}$ and $X_{i t}$ are time invariant and time variant individual controls including age and gender $\left(X_{i}\right)$, freelunch eligibility, limited English proficiency and a dummy indicating whether the student has special educational needs $\left(X_{i t}\right)$. Our specification also includes grade fixed effects $\left(\gamma_{g}\right)$, in the outcomes for which this is relevant, a full set of academic year fixed effects $\left(\delta_{t}\right)$, school dummies $\left(\mu_{s}\right)$, and all the non-linear interactions between school and academic year fixed effects $\left(\mu_{s} \cdot \delta_{t}\right)$ to control for cohort specific differences in performance across different schools. The standard errors are clustered at the country of origin or language level respectively for first and second generation immigrants.

Table 2 reports the results, for the first generation, for two measures of performance in mathematics: in levels, at grade 3 (the first time standardized tests are administered in Florida), and the change in performance from grade 3 to grade 8 , controlling for the initial condition at grade 3. Column 1 presents findings for test scores in mathematics when we control for age, gender, year, school fixed effects, and all their non-linear interactions. Column 2 includes the full set of individual controls (limited English proficiency, special education status, and free lunch) intended to capture the relevance of socio-economic status in school performance. The estimates show that first generation immigrants coming from countries with a high level of Long-Term Orientation have higher test scores in mathematics. The results remain strong after controlling for all the socioeconomic status variables, although the coefficient size decreases from 0.597 to 0.336 .

Differences in scores in mathematics could be related to differences in patterns of assimilation across migrants from different countries of origin. Therefore, Long-Term Orientation could simply pick up in a systematic way some of these unobserved differences in initial conditions. To rule out this confounding effect, we also look at the change in performance in mathematics from grade 3 until grade 8 , after controlling for the initial score in grade 3. These results are reported in columns 3-4. Coming from a long term oriented country not only gives students an initial advantage when they first test in grade 3, it also has an additional strong effect over a long time horizon, as the performance of these students continues to improve. From the specification in column 4: a one-standard-deviation increase in Long-Term Orientation (0.236) corresponds to a $0.051\left(0.236^{*} 0.217\right)$ of a standard deviation in change in math performance. To put this in perspective we can compare it to the effect of maternal education. While we do not have this variable for the sample of first generation students, in the population of second generation students for which the effect of Long-Term Orientation is 
similar, the typical child of a mother with a four-year college degree or more experiences a change in math performance of 0.052 of a standard deviation over the same time period. ${ }^{26}$ This specification is particularly compelling as we are able to control for the initial condition of the student (measured with the test score in grade 3), therefore further limiting the possibility that the results are driven by initial selection. Note also how the inclusion of the socio-economic characteristics in column 4 does not change substantially the size of the coefficient, an indication that the initial test score in grade 3 captures already most differences in socio-economic status.

Columns 5-8 restrict the sample to first generation immigrants who also speak one of the languages spoken in their place of birth. The results are even stronger. The coefficients on Long-Term Orientation is equal to 0.591 and 0.814 , with and without the inclusion of socio-economic status characteristics. As explained above, this increase in magnitude could be driven by a reduction of measurement error or because speaking the country of origin language is a manifestation of cultural attachment. When the dependent variable is the change in math scores between grade 3 and 8 , the coefficient is also larger in magnitude and almost double in size compared to the unrestricted sample.

Not only are the coefficient estimates statistically significant, but they are also economically meaningful. Based on the estimates of column 6, a one-standard-deviation increase in Long-Term Orientation (0.192) is associated with an increase in math score of $11.3 \%$ of a standard deviation $(0.591 * 0.192)$. The estimated impact of the same increase in Long-Term Orientation implies an increase in math performance of $10.4 \%$ of a standard deviation.

Table 3 reports the effect of Long-Term Orientation on other educational outcomes. ${ }^{27}$ The results show that overall there is a strong statistically significant relationship between Long-Term Orientation and various measures of school outcomes are generally large: A one standard deviation increase in Long-Term Orientation is associated with $8 \%$ of a standard deviation increase in reading levels and conditional reading gains, $7 \%$ of a standard deviation reduction in truancy, and $7 \%$ of a standard deviation reduction in disciplinary problems. When considering the dependent variables that are dichotomous, a one standard deviation increase in Long-Term Orientation is associated with a 0.35 percentage point reduction in grade retention and a 1.9 percentage point increase in graduation,

\footnotetext{
${ }^{26}$ We do not observe maternal education levels for foreign-born children, and therefore cannot control for or stratify by maternal education in the population of first generation students. However, we can do this for second generation immigrants, and we report the results of these analyses below.

${ }_{27}$ We only report the results for the restricted sample of the first generation (where we impose that the child should speak one of the main languages spoken in his/her country of origin). Results on the unrestricted sample are available from the authors.
} 
both large in relation to the $3.8 \%$ of students who are retained in any given year and the $20.9 \%$ who fail to graduate in the population.

Tables 4 and 5 report the results for all educational outcomes for second generation immigrants (defined using the foreign born status of the mother, her country of birth, when available or the language spoken at home) and the extended sample of second generation immigrants (defined only using the language spoken at home without any restriction on whether the mother is born abroad or not). It is interesting to note that the relative magnitude of the coefficients is very similar for the two groups and also almost identical to the magnitude of the results obtained with the sample of first generation immigrants. These results are consistent with the literature that show a remarkable persistence over time of cultural traits across generations (Albanese et al., 2016; Alesina et al., 2013; Algan and Cahuc, 2010; Fernández and Fogli, 2009; Giuliano, 2007; Guiso et al., 2006, 2016; Voigtlaender and Voth, 2012). The estimated effects for the continuous dependent variables range from a minimum of $5.2 \%$ of a standard deviation of the dependent variable (for truancy in the extended definition of second generation) to a maximum of $11.5 \%$ (for differences in math score at grade 3). All the beta coefficients are reported at the bottom of all our Tables.

Figures 4 and 5 present binned scatter-plots of the mean of different educational outcomes for first and second generation students versus the mean level of Long-Term Orientation. To construct this figure, we divided the horizontal axis into 40 equal-sized (percentile) bins and plotted a given mean education outcome versus the mean level of Long-Term Orientation in each bin. ${ }^{28}$ Consistently with our regression results, we do find a significantly strong relationship between LongTerm Orientation and educational outcomes for both generations.

In the analysis presented so far, we could include only a limited number of family control characteristics. For the sample of second generation immigrants (restricted and extended) we can also include the information about maternal characteristics contained in the birth certificates. In Table 6, we present the results for the extended sample of second generation immigrants where we include dummies for education, a dummy for whether the mother was younger than 16 when she gave birth (teen pregnancy), a dummy for whether the mother was married at time of birth, the number of older siblings, the income in the zip code of birth measured in 1999 (columns 1-5) and all controls included together (column 6). ${ }^{29}$

28 These regressions are estimated on the underlying microdata using OLS regressions.

${ }^{29}$ Results for the restricted version of the second generation are virtually identical and available from the authors. 
The controls have all the expected sign: a higher level of maternal education, being married at the time of birth and a higher income (proxied by the income in the zip code at birth) improve school performance; on the other hand, a larger family and teen pregnancy both reduce educational performance. The maternal characteristic with the largest economic effect is four years of maternal college degree: its coefficient of 0.385 indicates that a child of a mother with a college degree has a math score $40 \%$ higher than a child whose mother is a high school dropout. It is useful to compare this magnitude to the magnitude of the Long-Term Orientation coefficient. Moving from Puerto Rico's Long-Term Orientation (lowest) to South Korea's (the highest) the math score increases by $73 \%$. Another way to compare the economic significance of our results is to compare beta coefficients based on column 6 estimates. The beta coefficient of Long-Term Orientation for math score is equal to 0.10 , similar in size to the beta coefficient of a four-year college degree dummy (0.12) and much larger than the beta coefficient of other maternal characteristics, such as teen pregnancy $(-0.007)$, marital status (0.049), and the number of older siblings (-0.034). The Long-Term Orientation beta coefficient is also five times larger than the beta coefficient of the income in the zip code of residence at birth and substantially larger than the beta coefficient on the eligibility to free or reduced price lunch (-0.069). Only the beta coefficients of enrollment in a limited English proficiency program (-0.26) and of whether the student has special education needs (-0.22) are substantially larger.

In Table A4 we repeat our regressions on the other educational outcomes by including all maternal controls. The size and the significance of the coefficients on Long-Term Orientation are not affected by this inclusion.

\subsection{Controlling for country of origin observable characteristics}

A potential concern with the OLS estimates reported up to this point is that the Long-Term Orientation measure could capture some omitted country of origin characteristics. To attenuate this concern we control for additional country of origin observable characteristics ${ }^{30}$ (Table 7). We first introduce these controls one by one. The first obvious candidate is the level of GDP: if countries with higher Long-Term Orientation are also richer, a better performance of immigrants from these countries could be a reflection of differences in income (not fully captured by our free lunch control). Contrary to the argument above, students who come from a country with lower GDP perform better than immigrants from a higher GDP country, suggesting that selected students are more likely to come

\footnotetext{
${ }^{30}$ A detailed description of the country controls and their sources are provided in the Appendix.
} 
from poorer countries. Nonetheless, as shown in column 1, the inclusion of this control has little impact on the coefficient of interest.

Distance from the US could be another prominent determinant of differences in educational attainment: perhaps immigrants coming from countries farther away from the United States have higher determination and perseverance. Higher distance could be also correlated to a higher amount of initial resources necessary to move to the US. Indeed, distance from the US has a positive and significant effect on educational attainment, but, as shown in column 2, the coefficient of Long-Term Orientation remains robust to the inclusion of this control.

Galor and Ozak (2016) show that a culture emphasizing the future relatively more than the present has a direct positive effect on savings rates. As a result, differences in educational performance could be driven by differences in saving rates among immigrant groups and not directly related to differences in Long-Term Orientation, as higher savings may give the necessary resources for moving. We control for a measure of domestic savings over GDP in the country origin in column 3. Savings in the country of origin is not statistically significant and does not affect the coefficient on Long-Term Orientation.

Although we directly control for maternal education in our regressions, there are two other aspects of differences in education which is worth taking into account in our analysis. The first is a systematic difference in educational attainment between Florida immigrants from specific countries and their fellow citizen. If immigrants in Florida do not reflect a random sample of the population from which they came, Long-Term Orientation could be simply capturing the positive selection in the education of the immigrants. To address this issue, we follow Feliciano (2005) and construct an index of selection based on a comparative measure of immigrants' and non-immigrants' educational attainment adjusted for age along all points of the education distribution. ${ }^{31}$ For example, an index of 0.15 indicates that an immigrant's educational attainment probabilistically will exceed that of a nonimmigrants from the same country 15 percent more often than a non-immigrant's education will exceed the education of an immigrant from the same country. The higher this measure of selectivity, the more educated the immigrants are relative to the non-immigrant population in their home country. On the contrary, if immigrants are more often less educated than non-immigrants, the index of selectivity will be negative indicating negative selection. For our purpose, the concern is that LongTerm Orientation may be capturing part of this selection, in case Long-Term Orientation is correlated

31 The construction of this selection measure is described in detail in the Online Appendix. 
with Feliciano's selectivity measure. In our sample, the index of selectivity goes from a minimum of 0.10 (Mexico) to a maximum of 0.92 (Tanzania). China has an index of 0.62, very close to Argentina (0.60) whereas South Korea appears in the bottom part of the distribution (0.30). Overall, this measure appears very relevant in explaining differences in educational performance, but interestingly enough, the measure per se shows a very low (and negative) correlation with Long-Term Orientation. In addition, its inclusion in our specification leaves the coefficient of Long-Term Orientation almost unchanged (column 4 of Table 7).

The second concern is that differences in educational performance could be driven by differences in the quality of education in the country of origin, as reflected in reading and math scores. Higher quality of education received by the parents could be reflected later in higher achievement of the children as parents with higher quality of education could help their children doing homework more effectively. In column 5 we control for the average math score in the country of origin constructed from PISA. The coefficient on Long-Term Orientation is still significant, despite the much smaller number of immigrant groups included in the regression due to the availability of the data from PISA.

In column 6, we include all the country controls in one specification. Although the LongTerm Orientation coefficient is reduced in size, it remains highly significant and overall, the estimated impact is robust across the various specifications. The coefficients also remain fairly stable, ranging from 0.41 to 0.61 (for math score). Similar results are obtained for the change in mathematical performance from grade 3 to grade 8 (columns 7-12 of Table 7), where the coefficient varies from 0.29 to 0.41 . Results are also very similar when we repeat the same analysis for the extended version of second generation immigrants (Table 8), both in terms of magnitude and significance.

In the appendix (Tables A5 and A6) we report the robustness to the inclusion of these country controls to the remaining educational outcomes for first and second generation immigrants. ${ }^{32}$

We also test the robustness of our results to the inclusion of additional country of origin controls, including the log of the population in 2000, the Gini coefficient in 2000, the type of migrants (share of employed, and family-led diversity migrants over the total population of migrants) and a

\footnotetext{
32 The inclusion of the math score from PISA substantially reduces the sample. For that reason, in Panel A of Tables A5 and A6 (Online Appendix) we report the regressions without the inclusion of this control, whereas in Panel B of both Tables we repeat the regressions with the inclusion of this control. Also, the results for second generation immigrants (restricted) are very similar to the extended version and are reported in Table A7.
} 
measure of genetic distance from the US. The results, available from the authors, are robust to the inclusions of this larger set of controls.

\subsection{Robustness to sample selection}

In this section, we consider the robustness of our results to the use of different sub-samples. In Panel A of Table 9, given the similarity of results for the different generations, we pool together all the generations of immigrants and repeat the baseline regressions for this pooled sample, which we use for comparison for this set of results. ${ }^{33}$ In Panel B, we exclude the first and second generation immigrants coming from Latin America and Central America ${ }^{34}$, the biggest immigrant group in Florida. Since this group also tends to be in the bottom part of the educational performance distribution, by excluding them, we also test the robustness of the results to the exclusion of the approximate lower tail of the performance distribution. The results remain robust to the exclusion of this group. In addition, the magnitude of the beta coefficients remains similar (and are sometimes reduced) compared to the baseline specification of Panel A.

Asian immigrants are often considered a "model minority". Since immigrants from Asia tend to show the highest levels of Long-Term Orientation, we also test the robustness of our results to the omission of all Asian countries. Panel C shows that the results are robust to this exclusion and that our results are not driven by the group that is disproportionately represented among the top performers in our population. The beta coefficients, not surprisingly, are smaller when we exclude the top performers from our specification.

Overall, examining Figure 1, it is apparent that there exists some geographical cluster in LongTerm Orientation by continent. We also check that our results do not reflect these differences by adding continent dummies to the whole sample. The estimates are also robust to this procedure (Panel D), with almost no difference in terms of magnitude. ${ }^{35}$

\footnotetext{
${ }^{33}$ We only report the coefficient of Long-Term Orientation and omit to report the other controls (gender, age, free or reduced priced lunch, special education, and limited English proficiency). In these regressions, since we are merging generations based on language and country, we define the continent dummy based on both variables. The details of the construction of this variable are provided in the Online Appendix. Also, the constructions of the clusters are explained in the Online Appendix.

${ }^{34}$ Note that we define "Latin America" as all countries located in the Americas with the exclusion of Canada and the US.

${ }^{35}$ For the first generation, the continent dummy is equal to one if the country belongs to a given continent, 0 otherwise. As for language, we adopted the following rule: a language is assigned to a given continent if among the sample of first generation immigrants who speak that language at least $50 \%$ come from that specific continent.
} 


\subsection{Heterogeneous effects: family and peers}

So far, our analysis has assumed that Long-Term Orientation has similar effects for all individuals with a similar cultural background. However, the effect of Long-Term Orientation on educational outcomes could have heterogeneous effects, both in terms of family characteristics but also with respect to the interaction with peers of similar cultural background in the school where children study.

We test for these two possibilities separately in Tables 10 and 11. In Table 10, we include interaction terms between Long-Term Orientation and different family characteristics (including freelunch eligibility, number of older siblings, the zip code median income at birth and all maternal characteristics). We observe some heterogeneous estimated effects with the marital status and the level of education of the mother. Being married apparently reinforces the effect of Long-Term Orientation (column 6); mother's education, surprisingly, reduces it, although in a non-linear way. Perhaps if the mother dropped out of high school, she is more likely to stay at home and socialize her children to her values. Despite the negative effect on the interaction terms of the mother's educational dummies, the overall effect of Long-Term Orientation remains positive and significant, even when we include as regressors all the interactions in the same specification (Column 6). Table A8 finds similar results for all other educational outcomes.

The fraction of children speaking the same language in a given school may also play an important role in transmitting and preserving the importance of Long-Term Orientation: If cultural transmission is important, the larger the fraction of children speaking the same language in a school, the larger should be the effect of Long-Term Orientation on school performance. Note that this fraction depends on the extent to which a group tends to cluster in a school but also on how large a group speaking a given language is.

We calculate a proxy for cultural density as the proportion of children speaking a given language in each school for every academic year. For each language, the numerator is therefore given by the number of children speaking a given language in the school in a year, whereas the denominator is the number of all students in the school (including non-immigrants) in that year. Although the average fraction of students speaking a given language in a school is fairly low in our sample (lower than one percent) there is a substantial heterogeneity in our sample, with some languages reaching up to $38 \%$ in a given school/year. Languages with high percentages other than English, Spanish, and Haitian Creole, the three most commonly spoken languages in Florida, include French, Hebrew, Russian, Vietnamese, Chinese, Serbian, Arabic and Portuguese. 
We attach to each child speaking a given language, his/her own measure of cultural density by school and academic year. To limit the possibility that our results are biased by some languages that are spoken by a very large fraction of students and in order to capture sufficient variation, we drop from the sample the students speaking Spanish, Haitian Creole, or English. ${ }^{36}$

The results are reported in Table 11. Across all specifications, a higher fraction of children speaking the same language of the student has a negative and significant effect on the student's educational attainment for almost all outcomes. ${ }^{37}$ This is not surprising, given that speaking a language different than English can have some impediment on the learning process and a larger fraction of students speaking a foreign language can reduce a student's incentive to speak English. However, interestingly, the interaction between Long-Term Orientation (based on the language spoken by the student) and the fraction of students speaking the same language in school is positive and significant. In addition, the full marginal effect of Long-Term Orientation remains positive and significant when evaluated at the mean of cultural density: a one standard deviation increase in Long-Term Orientation is associated, for example, with a $11.5 \%$ standard deviation increase in math level. The degree to which children cluster in the same school appears to be an important vehicle to explain the effect of LongTerm Orientation on educational outcomes. ${ }^{38}$

\subsection{Potential mechanisms}

In this section, we look at some additional outcomes and try to shed some light on some possible mechanisms linking Long-Term Orientation and school performance. We begin by studying the probability of being enrolled in advanced classes in high school and also at the probability of choosing advanced scientific classes. Both could be another manifestation of Long-Term Oriented attitudes. Advanced classes require hard work and perseverance today in exchange for future rewards, as measured for instance by access to better colleges which normally reward a more rigorous curriculum. Also scientific subjects, on average, give access to better paying jobs. Furthermore, we provide evidence for ways in which parents with higher Long-Term Orientation may contribute to

\footnotetext{
36 These observations are dropped only from the numerator (and the regressions), while they will be part of the denominator, which includes the total population of each school.

${ }^{37}$ It is interesting to note that the fraction of students speaking the same language in a school is significant only when the Long-Term Orientation variable is also included. When we run a regression only with the fraction of students speaking the same language as a control, this variable is only significant when the LHS variables are reading scores in grade 3 , disciplinary incidents, and retention. In these three cases the cultural density variable has a negative effect on all three educational outcomes.

38 When the left hand side variable is the change in scores between $3^{\text {rd }}$ grade and $8^{\text {th }}$ grade we interact LongTerm Orientation with our variable of cultural density either in $3^{\text {rd }}$ grade (the first time the student was tested) or in $8^{\text {th }}$ grade. The results are similar in the two specifications.
} 
their children's success by selecting better schools and successfully enrolling their children in a gifted program. We examine all these outcomes in Table $12 .{ }^{39}$

We start by looking at whether there is a direct link between Long-Term Orientation and being enrolled in advanced placement or equivalent classes in high school and whether this correlation also exists for advanced placement classes in scientific subjects (columns 1-2). We include our standard controls but also add performance in mathematics at grade 8 . The effect is statistically significant and also has a large effect for both outcomes (the beta coefficients are equal to 0.09 and 0.10 respectively).

We then examine whether children coming from Long-Term Oriented families go to better schools, controlling for the school district of residence. Starting in 1996 the Florida Department of Education required school districts to design an open enrollment plan which allows parents to choose among several options including magnet schools, schools-within-schools, alternative schools, yearround schools, dual enrollment, and controlled open enrollment schools. We study whether parents with high Long-Term Orientation are more likely to either use Florida's school choice programs or otherwise choose neighborhoods served by better schools, as measured by the quality reported by the Florida Department of Education. In each district parents have access to the schools' scores before enrollment. These school scores have 5 possible letter grades, from A to F, which we coded from worst (1) to best (5). Since school's letter scores change frequently and it is unlikely that parents reoptimize every year, in column 3 we regress the quality of the school chosen the first time the student enters the public school system (in kindergarten or pre-kindergarten) - the time when school choice is most relevant -- on Long-Term Orientation. In column 4, we also repeat the analysis by regressing the school score in any grade on Long-Term Orientation. ${ }^{40}$ The results are very similar: Families coming from Long-Term Oriented societies actively choose better schools (the beta coefficient is equal to 0.058 and 0.052 respectively) within their school district.

All of the previous mechanism analyses point toward a pattern in which families from high Long-Term Oriented backgrounds take active steps to secure good outcomes for their children. There exists one outcome in the administrative data that is especially conducive to studying the likely role of direct parental involvement in school decisions - whether a student is enrolled in a school's gifted program. Though there are differences across school districts in the implementation of gifted programs, the state of Florida mandates that each district is responsible for providing an appropriate

39 The definition of these variables is given in section 2.1.2.

${ }^{40}$ In this regression we use the school score at time $\mathrm{t}-1$. This is the school score that the family observes at the time of enrollment. 
program that serves all exceptional students and the State Board of Education provides oversight over district plans. By fourth and fifth grade, most elementary schools in Florida offer separate full-time instruction for gifted students. To qualify for being included in gifted instruction, students have two routes. The first way is to submit an IQ test above the state cutoffs. Students could be tested by either a district psychologist or by a private psychologist and submit the results to the school. Students with IQs above the relevant threshold are eligible for gifted status, with the final determination made in consultation between parents, teachers, and the school's Exceptional Student Education (ESE) specialist. Alternatively, seats in the gifted classrooms are filled by non-gifted students -- known as high achievers -- who scored highest among their school/grade cohort in statewide achievement tests in the previous year.

While we do not have information on external tests, we have a mechanism for testing the degree to which immigrant students ultimately receive gifted instruction. Our approach is as follows: We look at the set of students who were not yet classified as gifted in third grade, before the first statewide assessment, but then who received the highest performance (level 5) rating on either mathematics or reading and either a level 4 or 5 on the other test, and then see whether, conditional on being in this rarefied group of exceptionally high achievers, the student is enrolled in the gifted program in the following year. We find that children coming from Long-Term Oriented cultures are more likely to be enrolled in a gifted program and the effect is again sizeable (a beta coefficient of $0.05)$.

These last two results are important. First, they confirm that parents from countries with a long-term oriented culture appear to care relatively more about education and, despite the cultural barriers that a foreign school system poses to immigrant families, they are determined to use the rules of the system to secure better educational opportunities for their children. Indeed, part of the higher educational achievement of immigrants coming from countries with high Long-Term Orientation may be the result of a direct intervention of parents selecting better schools and advocating for the inclusion of their children in gifted programs. This evidence, together with the one presented on the importance of having students speaking the same language attending the same school, is also consistent with models of cultural transmission emphasizing the relevance of social learning (Boyd et al., 2011): children are more likely to internalize the value transmitted by their parents if people around them behave in a similar way. 


\subsection{Alternative measures of Long-Term Orientation}

We finally consider the robustness of our results to the use of two alternative proxies for LongTerm Orientation. We first look at linguistic differences in the use of the future tense as a proxy for the relevance of future-oriented versus present oriented actions. Chen (2013) uses the fact that languages differ in the way they grammatically mark future events and test whether this difference has an effect on savings, health behavior, and retirement assets. His idea is that languages that grammatically separate the future and the present lead speakers to dissociate the future from the present. This would make the future feel more distant, therefore making future-oriented choices harder. On the other hand, if the language makes the present and the future indistinguishable, its speakers will be more willing to take future-oriented actions, because they appear to be closer in time.

Chen (2013) distinguishes languages in two groups: those that have a strong future-time reference and those that do not. The measure has been constructed by the European Science Foundation's Typology of Languages in Europe (EUROTYP) project. According to this criterion, languages are classified as "futureless" if they do not require "obligatory use in prediction-based contexts". To use one of Chen's (2013) examples: "if I wanted to explain to an English-speaking colleague why I can't attend a meeting later today, I could not say 'I go to a seminar'. English grammar would oblige me to say 'I will go,' 'I am going,' or 'I have to go to a seminar.' If on the other hand I were speaking Mandarin, it would be quite natural for me to omit any marker of future time and say the equivalent of I go listen to a seminar, with no reference to future time, since the context leaves little room for misunderstanding. In this way, English forces its speakers to habitually divide time between the present and the future in a way that Mandarin (which has no tenses) does not." According to Chen's hypothesis, in our specification therefore Futureless languages should be positively correlated to educational performance.

In Table 13, Panel A, we report the impact of speaking a futureless language on all our measures of educational performance: The similarity with our main results is remarkably strong, in terms of both magnitude and significance. We match all the immigrants with Chen's linguistic measure using the language spoken at home. One big advantage of matching directly on language is the possibility of including (at least for the first generation) country of origin fixed effects, further reducing the possibility that our results are driven by unobservable country of origin characteristics. Performing this very demanding test does not change the nature of our results: linguistic differences that proxy for a different weight to future and present choices are sufficient in explaining differences in educational performance (Table 13, Panel B). 
The fraction of students speaking a futureless language in our sample is not very large $(2 \%)$ given the large fraction of Spanish speaking students (coded as zero). Therefore, we also run our regressions excluding from the sample Spanish speaking countries from both the pooled sample and the first generation sample and the results do not change (Table A9).

Galor and Ozak (2016) study the origins of the distribution of Long-Term Orientation across the world. They establish empirically that these differences can be traced back to geographical variations in the return to agricultural investment in pre-industrial societies: societies whose ancestors experienced a higher crop yield are characterized by higher Long-Term Orientation today. The authors test their hypothesis constructing a measure of the potential caloric yield per hectare for each country. Their historical measure of crop yield is constructed based on data from the Global Agro-Ecological Zones (GAEZ) project of the Food and Agriculture Organization (FAO). The GAEZ project supplies global estimates of crop yield for a variety of crops in grids with cell size of 5' X 5'. For each crop, GAEZ also provides estimates for crop yield based on three alternative levels of inputs (high, medium and low) and two source of water supply (rain-fed and irrigation). The authors construct their measure under low level of inputs and rain-fed agriculture to limit concerns of endogeneity due to human intervention. ${ }^{41}$

We use the measure constructed by Galor and Ozak (2016) and test its relevance for the determination of school performance. Panel C establishes a positive statistically and economically significant effect of crop yield on school performance. In particular, the OLS effects suggest that the magnitude of the beta coefficients is very similar to the magnitude of Hofstede's Long-Term orientation measure (for example, the beta coefficients for math score and math change are 0.097 and 0.089). Consistent with Galor and Ozak's (2016) theory, individuals whose ancestors experienced higher crop yields exhibit long-term oriented behavior. ${ }^{42}$

${ }^{41}$ We use the ancestry adjusted measure for the post-1500 CE period. Given the large fraction of migrants speaking Spanish and coming from the new world, where intercontinental migration and population replacement were very high, we limit our attention to the Old World sample. For further details about the construction of this measure see Galor and Ozak (2016).

${ }^{42}$ In a recent paper, Dohmen et al. (2015) construct a measure of patience which should isolate the trade-offs between immediate and delayed monetary rewards. This measure is part of a larger project, the Global Preference Survey, measuring time preferences, risk preferences, social preferences and trust from representative populations of 76 countries. The patience measure is derived from a combination of responses to two survey measures, one with a quantitative and one with a qualitative format. These two were the best predictors of behavior in experiments involving incentive choices between earlier versus later rewards with a time delay of 12 months, therefore capturing annual discounting. We would like to test the robustness of our results to this measure, when the data will be made available from the authors to other scholars. 


\subsection{Relative performance of immigrants and natives}

One final concern with our analysis is the possibility that immigrants (especially the first generation) face a disadvantage in their new school environment. Our regressions could therefore pick up a reversion to the mean (the average performance of natives). To show that this is not the pattern in the data, we plot the performance of migrants compared to the group of natives. To perform this exercise, we keep students who are observed in our panel from grade 3 to grade 8, we then first collapse math and reading scores by country of origin (or language spoken at home) and then by immigrant group (first and second generation).

In Figure 6A we report the performance of natives, first, and second generation immigrants from grade 3 to grade 8 . Not only immigrants start at higher level compared to the natives but their performance also continues to increase over time, whereas the performance of natives stays flat. Given the large difference in educational performance by race in the United States, in the same figure we also report test scores for native whites. Although the scores of white students are higher in level when compared to the overall sample, immigrants tend to out-perform white natives over time in both mathematics and reading ${ }^{43}$. Once again, the performance of white natives is flat over time. In comparing the first and the second generation, it appears that the second generation tends to be closer to the natives. This result is not surprising as these children are born and raised in the US and, therefore, they are less isolated from the dominant culture. ${ }^{44}$

Since part of the immigrants' school performance appears to be driven by school selection, to gain further understanding of the differences between immigrants and natives, we also compare the three groups in the best schools (those receiving a score of A). Schools have definitely a strong relationship with educational performance (the scores are higher for the three groups compared to the averages in the overall sample) but the differential patterns between the three groups remain the same. This is an important result. It suggests that immigrants outperform natives, even holding constant the school institutional environment (Figure 6B), and it is consistent with Chetty and Hendren (2015)'s finding that local conditions matter less for immigrants. In Figure 7 we plot the performance in mathematics and reading by Long-Term Orientation quartiles and for white natives. Note that the Long-Term Orientation for the United States is 0.26 , close to the lowest quartile of our immigrants'

\footnotetext{
43 White natives have slightly higher scores in reading only at grade 3.

${ }^{44}$ Second generation immigrants in our sample are not the children of the first generation in our sample. The differences compared to the white could still be due to differences in the cohort of migration of the first generation.
} 
distribution. ${ }^{45}$ We find a remarkably monotonic effect of Long-Term Orientation on math and reading scores: only immigrants with Long-Term Orientation lower than the natives perform worse in both mathematics and reading.

Overall, these results suggest that especially immigrants with higher Long-Term Orientation lose some of their cultural advantages when they assimilate to the US culture. In our setting, it is hard to measure the full effect of assimilation because, by definition, our immigrants have not fully assimilated as they continue to speak a language different from English. Özek and Figlio (2016) find that the Asian or Hispanic students who speak English at home perform worse than other Asian and Hispanic students who are first or second generation immigrants. The broader classification based on race, however, could mask large differences in composition because each race shows a large heterogeneity in terms of cultural values.

\section{External Validity from the Program for International Student Assessment (PISA)}

For external validity, we use student-level data from the Program for International Student Assessment (PISA), an internationally standardized assessment conducted by the Organization of Economic Cooperation and Development (OECD) and administered to 15-year olds students every three years since 2000. We use the 2003, 2006, 2009 and 2012 waves. ${ }^{46}$ PISA contains information on the country of origin of children and their parents. The analysis based on this dataset can therefore be more precise for second generation immigrants, since it is based on the parental country of origin and not the language spoken at home. For consistency with the Florida analysis, we define second generation immigrants based on maternal information. ${ }^{47}$ The list of countries of origin for first and second generation is provided in the appendix (Table A11). ${ }^{48}$

PISA assesses a range of relevant skills in three main domains: mathematics, reading, and science. For these domains PISA presents the test scores in standardized forms, with mean of 500 test-score points and a standard deviation of 100 test-score points across OECD countries. ${ }^{49}$ To make

\footnotetext{
${ }^{45}$ Long-Term Orientation for the bottom $25^{\text {th }}$ percentile is 0.21 .

46 We use these waves because in 2000 the information about the countries of origin of the parents is not provided (the questionnaire only asks if the students and/or their parents were born in the country where the student took the test).

${ }^{47}$ Results based on fathers' country of origin are presented in Table A12 of the Appendix. They show that the effects are very similar.

48 The countries of destination included in our analysis are reported in Table A11.

${ }^{49}$ For details on how PISA reports student scores see the on-line Appendix.
} 
these results comparable with the analysis for Florida we re-standardized all the scores to zero mean and unit variance.

In addition to test scores, PISA also provides information on retention and truancy. Retention is a dummy variable equal to 1 if a student repeated at least one year during his/her school career and 0 if she/he did not. Truancy is a dummy variable equal to 1 if the student reported that in the last two full weeks of school he/she skipped a whole school day more than once, and zero otherwise. ${ }^{50}$ Descriptive statistics for our sample are provided in Table 14.

Overall we are able to provide external validity for most of the outcomes present in the FLDOE dataset, the only exception being the changes in mathematics and reading scores over time, which cannot be calculated due to the cross-sectional nature of PISA.

We start by examining the raw correlations between Long-Term Orientation and the five educational outcomes for both first and second generation immigrants (Figures 8 and 9). Although we are now observing immigrants or their children in thirty-seven different destination countries, the basic correlation between Long-Term Orientation and educational performance appears to be very similar to the one observed among immigrants in Florida.

The results are confirmed when we run individual level regressions for the two immigrant groups (Tables 15 and 16). Our specification is similar to the Florida dataset. Our controls include gender, age, parental education, grade and country of destination fixed effects (columns 1-5 of Tables 15-16). PISA also contains an index for family wealth, an important control as differences in educational performance could be driven by differences in the initial level of resources among different immigrant groups. We control for this index in columns 6-10. The inclusion of wealth, if something, makes our results more precisely estimated. The results are similar between the two groups, though slightly stronger for second generation immigrants. Despite we use a very different set of destination countries from the US, it is remarkable that the magnitudes of the Long-Term Orientation beta coefficients reported at the bottom of each table have a similar order of magnitude to the Long-Term Orientation beta coefficients estimated in the Florida sample.

Finally, Figures 10 and 11 present binned scatter plots of the mean of different educational outcomes for first and second generation students in PISA versus the mean level of Long-Term Orientation. As for Figures 4 and 5 to construct this figure, we divided the horizontal axis into 40 equal-sized (percentile) bins and plotted the mean education outcome versus the mean level of Long-

50 This variable is present only in the 2012 PISA wave. 
Term Orientation in each bin (using OLS regressions on the microdata). Consistent with our regression results, we do find a significantly strong relationship between Long-Term Orientation and educational outcomes for both generations.

\section{Conclusions}

This paper explores the role of Long-Term Orientation on educational attainment and outcomes. It establishes that, controlling for the quality of schools and individual characteristics, immigrant students from countries with long term oriented attitudes perform better in school than immigrants from countries that do not emphasize the importance of delayed gratification. Coming from a long term oriented country not only gives students an initial advantage when they first test in grade 3 in both math and reading, it also has an additional strong effect over time, as the performance of these students continues to improve relatively to students coming from less long term oriented cultures. Also, students from long term oriented cultures have fewer absences, fewer disciplinary incidents, are less likely to repeat the same grade and are more likely to graduate from high school in four years. Finally, they are more likely to enroll in advanced level classes while in high school and to be more likely to select, among these, scientific subjects.

Parental intervention appears to be an important channel of cultural transmission: Parents are more likely to choose highly ranked schools and to advocate for inclusion in gifted programs, controlling for students' achievement level. At the same time, we also find that the composition of the school, in particular the fraction of children speaking the same language, magnifies the effect of Long-Term Orientation on educational performance. Both results are consistent with the idea that social learning (Boyd et al., 2011) is an important channel of cultural transmission: children are more likely to internalize the value transmitted by their parents if people around them (family and peers) behave in a similar way.

Our results also show that, independently from formal institutions (schools and neighborhoods), both first and second generation immigrants from countries with longer term oriented attitudes than the US perform substantially better than native US students. We validate these results with a sample of student immigrants to other non-US countries.

Our results can finally shed light on the remarkable persistence found in the educational literature. Besides income, wealth, and education, parents transmit cultural traits to their children. If Long-Term Orientation is an important trait to explain educational outcomes, disentangling its independent effect on educational outcomes is important for policy implications. Our results can 
partially explain why the exogenous effect of a sudden shock to income, albeit significant, has a relatively small economic impact on future generations, especially if compared with the limited mobility across generations.

Our results may also shed light on why, despite the importance of socioeconomic background for students' achievement, a substantial exogenous shock to wealth has limited or no effect on future generations. Bleakley and Ferrie (2016) find indeed that the children and grandchildren of winners of the 1832 Cherokee Land Lottery did not experience better educational outcomes than non-winners, suggesting that wealth shocks alone are insufficient to have persistent effects in the formation of human capital of future generations. More importantly, it suggests that part of the correlation that we observe across generations in educational achievement is driven by some other characteristics different from wealth that are transmitted along family lines. In this paper, we have shown evidence consistent with Long-Term Orientation being culturally transmitted from parents to children.

Beyond finding evidence of parental transmission of values, our results are also consistent with the existence of non-parental channels of cultural transmission, consistently with Algan et al. (2013). Our findings that the impact of Long-Term Orientation also depends on school composition could also explain why observed school quality do not fully account for the differences across schools in the number of high-achieving students (Ellison et al., 2016) suggesting that the school's cultural composition may potentially play an important role in students' performance. The full impact of schools' cultural composition on the educational performance of the overall student body is left for future research. 


\section{References}

Abramitzky, Ran, Leah Platt Boustan, Katherine Eriksson (2014), A Nation of Immigrants: Assimilation and Economic Outcomes in the Age of Mass Migration, Journal of Political Economy, 122:3, 467-717, June 2014.

Albanese, G., G. De Blasio, and P. Sestito (2016) "My parents taught Me. Evidence on the family transmission of values," Journal of Population Economics, 29:571-592.

Alesina, Alberto, Paola Giuliano, and Nathan Nunn (2013) "On the Origin of Gender Roles: Women and the Plough," Quarterly Journal of Economics, 128(2): 469-530

Alesina, Alberto and Paola Giuliano (2015), "Culture and Institutions," Journal of Economic Literature, December 2015, 53(4): 898-944.

Algan, Yann and Pierre Cahuc (2010) "Inherited Trust and Growth," American Economic Review, 100(5): 2060-92.

Algan, Yann, Pierre Cahuc, and Andrei Shleifer (2013) "Teaching Practice and Social Capital," American Economic Journal: Applied Economics, 5(3): 189-210

Becker, Sascha O., Katrin Boeckh, Christa Hainz and Ludger Woessmann (2016), The Empire is Dead, Long Live the Empire! Long-Run Persistence of Trust and Corruption in the Bureaucracy, The Economic Journal, 126(2): 40-74.

Bisin, Alberto and Thierry Verdier (2000), "Beyond the Melting Pot: Cultural Transmission, Marriage, and the Evolution of Ethnic and Religious Traits, Quarterly Journal of Economics, CXV (3), 955988 ,

Bisin, Alberto and Thierry Verdier (2001), "The Economics of Cultural Transmission and the Dynamics of Preferences," Journal of Economic Theory, 97, 298-319.

Black, Sandra E., Paul J. Devereux, and Kjell G. Salvanes (2005) 'Why the Apple Doesn't Fall Far: Understanding Intergenerational Transmission of Human Capital," American Economic Review, 95(1): 437-449.

Bleakley, Hoyt and Joseph Ferrie (2016), "Shocking Behavior: Random Wealth in Antebellum Georgia and Human Capital Across Generations," Quarterly Journal of Economics, forthcoming.

Boyd, Robert, Peter J. Richerson, and Joseph Henrich (2011), “The cultural niche: Why social learning is essential for human adaptation," Proceedings of the National Academy of Sciences, 108 (Supplement 2) $10918-10925$. 
Card, David, John E. Di Nardo and Eugena Estes (2000), “The More Things Change: Immigrants and the Children of Immigrants in the 1940s, the 1970s, and the 1990s," in George J. Borjas, editor, Issues in the Economics of Immigration, Chicago: University of Chicago Press.

Chen, Keith M. (2013), “The Effect of Language on Economic Behavior: Evidence from Savings Rates, Health Behaviors, and Retirement Assets," American Economic Review, 103(2): 690-731.

Chetty, Raj and Nathaniel Hendren (2015), “The Impacts of Neighborhoods on Intergenerational Mobility: Childhood Exposure Effects and County-Level Estimates,” working paper.

Chevalier, Arnaud, Kevin Denny, and Norren McMahon (2009), “A Multi-county Study of Intergenerational Education Mobility," in Peter Dolton, Rita Asplundh, and Erling Barth, editors, Education and Inequality Across Europe, London: Edward Elgar.

Dahl, Gordon B. and Lance Lochner (2012), “The Impact of Family Income on Child Achievement: Evidence from the Earned Income Tax Credit," American Economic Review, 102(5): 1927-1956.

Doepke, Mathias and Fabrizio Zilibotti (2008), "Occupational Choice and the Spirit of Capitalism," The Quarterly Journal of Economics, 123(2), 747-793.

Doepke, Mathias and Fabrizio Zilibotti (2015), "Parenting with Style: Altruism and Paternalism in Intergenerational Preference Transmission," working paper.

Dohmen, Thomas, Benjamin Enke, Armin Falk, David Huffman, Uwe Sunde (2015), "Patience and The Wealth of Nations," working paper.

Ellison, G. and A. Swanson, 2016, "Do Schools Matter for High Math Achievement? Evidence from the American Mathematics Competition”, American Economic Review, 106 (6): 1244-1277.

Feliciano, Cynthia (2005), "Does Selective Migration Matter? Explaining Ethnic Disparities in Educational Attainment among Immigrants' Children,” The International Migration Review, Vol. 39, No. 4, pp. 841-871.

Fernández, Raquel and Alessandra Fogli (2009), "Culture: An Empirical Investigation of Beliefs, Work, and Fertility," American Economic Journal: Macroeconomics, 1 (1): 146-177.

Figlio, David, Jonathan Guryan, Krzysztof Karbownik, and Jeffrey Roth (2014), "The Effects of Poor Neonatal Health on Children's Cognitive Development," American Economic Review 104 (12): 3921-3955.

Figlio, David and Larence Kenny (2009), "Public Sector Performance Measurement and Stakeholder Support," Journal of Public Economics 93 (9-10): 1069-1077.

Figlio, David and Maurice Lucas (2004), "What's in a Grade? School Report Cards and the Housing Market," American Economic Review 94 (3): 591-604. 
Fryer, Roland, and Steven Levitt (2004), "Understanding the Black-White Test Score Gap in the First Two Years of School," Review of Economics and Statistics 86 (2): 447-64

Galor, Oded and Stelios Michalopoulos (2012), "Evolution and the Growth Process: Natural Selection of Entrepreneurial Traits," Journal of Economic Theory, 147, 759-780.

Galor, Oded and Omer Moav (2002), "Natural Selection and the Origin of Economic Growth," Quarterly Journal of Economics, 117, 1133-1192,

Galor, Oded and Omer Ozak (2016), “The Agricultural Origins of Time Preference," American Economic Review, forthcoming.

Guiso Luigi, Paola Sapienza, and Luigi Zingales (2006), “Does Culture Affect Economic Outcomes?,” The Journal of Economic Perspectives, 20(2): 23-48.

Guiso, Luigi, Paola Sapienza, and Luigi Zingales (2008), "Social Capital as Good Culture” Journal of the European Economic Association 6 (2-3): 295-320.

Guiso, Luigi, Paola Sapienza, and Luigi Zingales (2016), “Long Term Persistence," The Journal of European Economic Association, forthcoming.

Giuliano, Paola (2007), "Living Arrangements in Western Europe: Does Cultural Origin Matter?” Journal of the European Economic Association, 5(5): 927-952.

Hanushek, Eric A. and Ludger Woessmann (2010), “The Economics of International Differences in Educational Achievement," IZA Working paper.

Hertz, Tom, Tamera Jayashadera, Patrizio Piraino, Sibel Selcuk, Nicole Smith, and Alina Verashchagina (2007), "The Inheritance of Educational Inequality: International Comparisons and Fifty-year Trends", B.E. Journal of Economic Analysis and Policy 7, article 10.

Hofstede, Geert (1991), Cultures and organizations: software of the mind, McGraw-Hill, London.

Hofstede, Geert, Gert Jan Hofstede, and Michael Minkov (2010), Cultures and organizations: software of the mind: intercultural cooperation and its importance for survival, 3rd ed., McGraw-Hill, New York.

Krapohl, E., Rimfeld, K., Shakeshaft, N. G., Trzaskowski, M., McMillan, A., Pingault, J.-B., ... Plomin, R. (2014) "The high heritability of educational achievement reflects many genetically influenced traits, not just intelligence," Proceedings of the National Academy of Sciences of the United States of America, 111(42), 15273-15278.

LiCalsi, Christina, Umut Özek, and David Figlio (2016), “The Uneven Implementation of Universal School Policies: Maternal Education and Florida's Mandatory Grade Retention Policy," Northwestern University working paper. 
Mischel, Walter, and Ebbe B. Ebbesen (1970) “Attention in delay of gratification,” Journal of Personality and Social Psychology, 16(2): 329-337.

Mischel, Walter, Yuichi Shoda, and Philip K. Peake (1988), “The nature of adolescent competencies predicted by preschool delay of gratification," Journal of Personality and Social Psychology, 54, 687696.

Mischel, Walter, Yuichi Shoda, and Monica L. Rodriguez (1989), "Delay of gratification in children," Science, 244, 933-938.

Nunn, Nathan and Leonard Wantchekon (2011), “The Slave Trade and the Origins of Mistrust in Africa," American Economic Review, 101(7): 3221-3252.

Özek, Umut and David Figlio (2016) “Cross-Generational Differences in Educational Outcomes in the Second Great Wave of Immigration,” NBER working paper.

Reardon, Sean F. and Claudia Galindo (2009), "The Hispanic-White achievement gap in math and reading in the elementary grades," American Educational Research Journal, 46, 853-891.

Rouse, Cecilia Elena and Lisa Barrow (2006) “U.S. Elementary and Secondary Schools: Equalizing Opportunity or Replicating the Status Quo?” The Future of Children, Vol. 16 (2): 99-123.

Rothstein, Jesse and Nathan Wozny (2013) "Permanent Income and the Black-White Test Score Gap," Journal of Human Resources 48(3), 510-544.

Sacerdote, Bruce (2005) "Slavery and the Intergenerational Transmission of Human Capital," The Review of Economics and Statistics, Vol. 87 (2): 217-234.

Shoda, Yuichi, Mischel Walter, and Philip K. Peake (1990), "Predicting adolescent cognitive and social competence from preschool delay of gratification: Identifying diagnostic conditions," Developmental Psychology, 26, 978-986.

Tabellini, Guido (2008), "The Scope of Cooperation: Values and Incentives," Quarterly Journal of Economics, 123 (3), 905-950.

Voigtlander, Nico and Joachim Voth (2012), "Persecution Perpetuated: The Medieval Origins of AntiSemitic Violence in Nazi Germany," Quarterly Journal of Economics, 127(3): 1339-1392. 
Figure 1

Long-Term Orientation, Hofstede (2010)
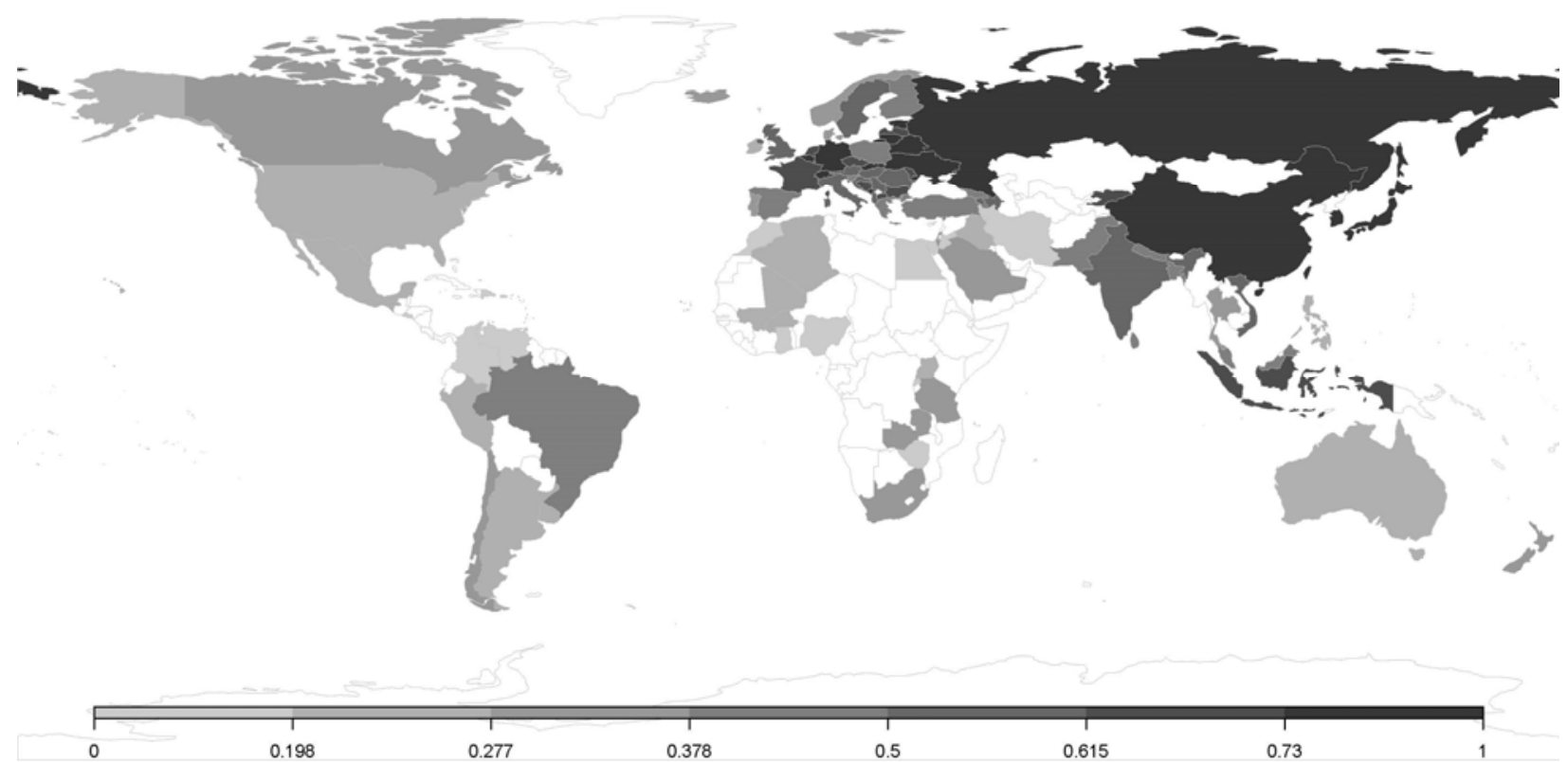

Note: White areas indicate missing values 


\section{Figure 2}

\section{Long-Term Orientation and educational outcomes, raw correlation, FLDOE}

\section{First generation immigrants}
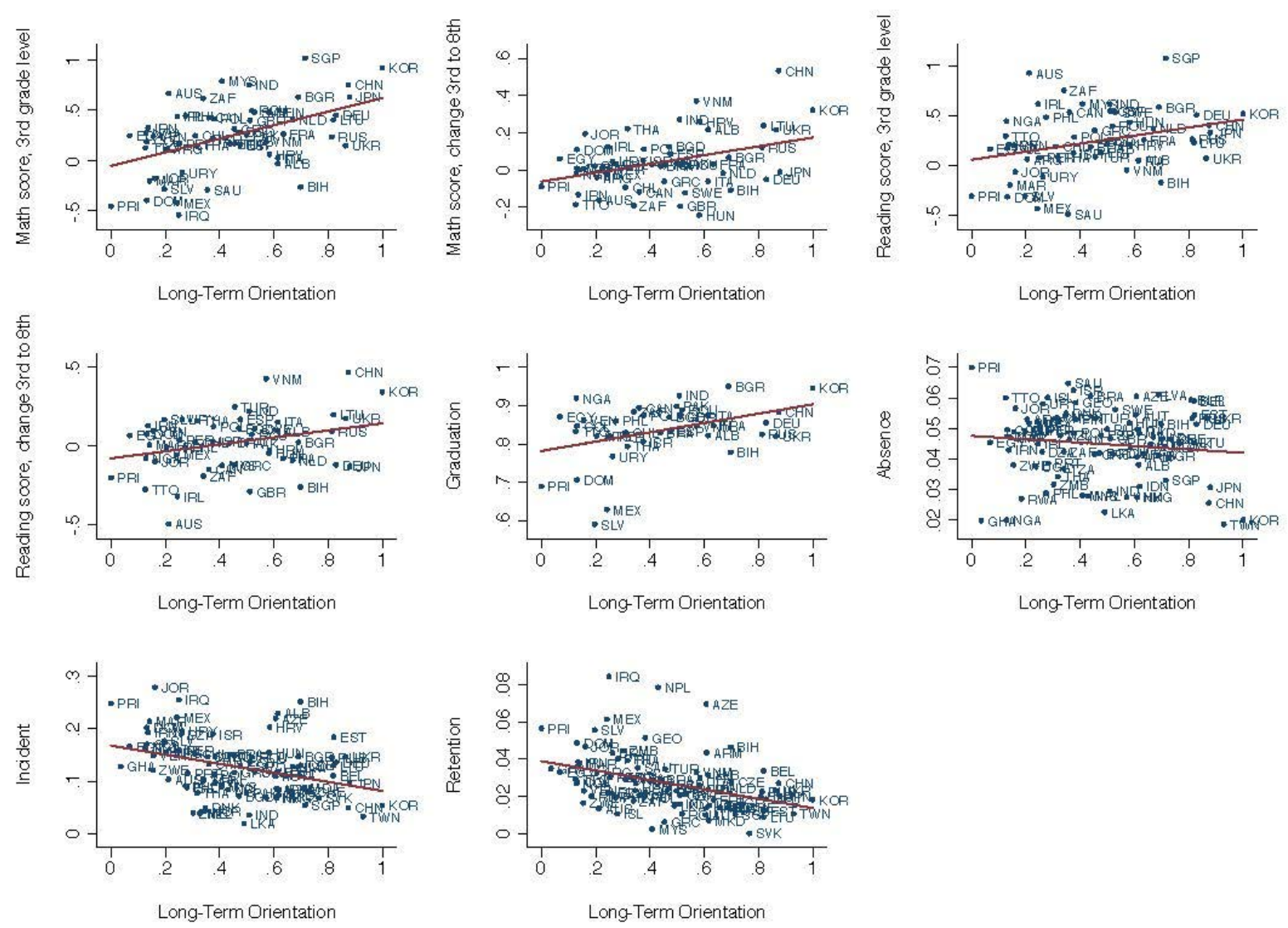

For purposes of confidentiality, we only show data points for countries of origin where we observe at least 50 individuals. 


\section{Figure 3}

\section{Long-Term Orientation and educational outcomes, raw correlation, FLDOE Second generation immigrants}
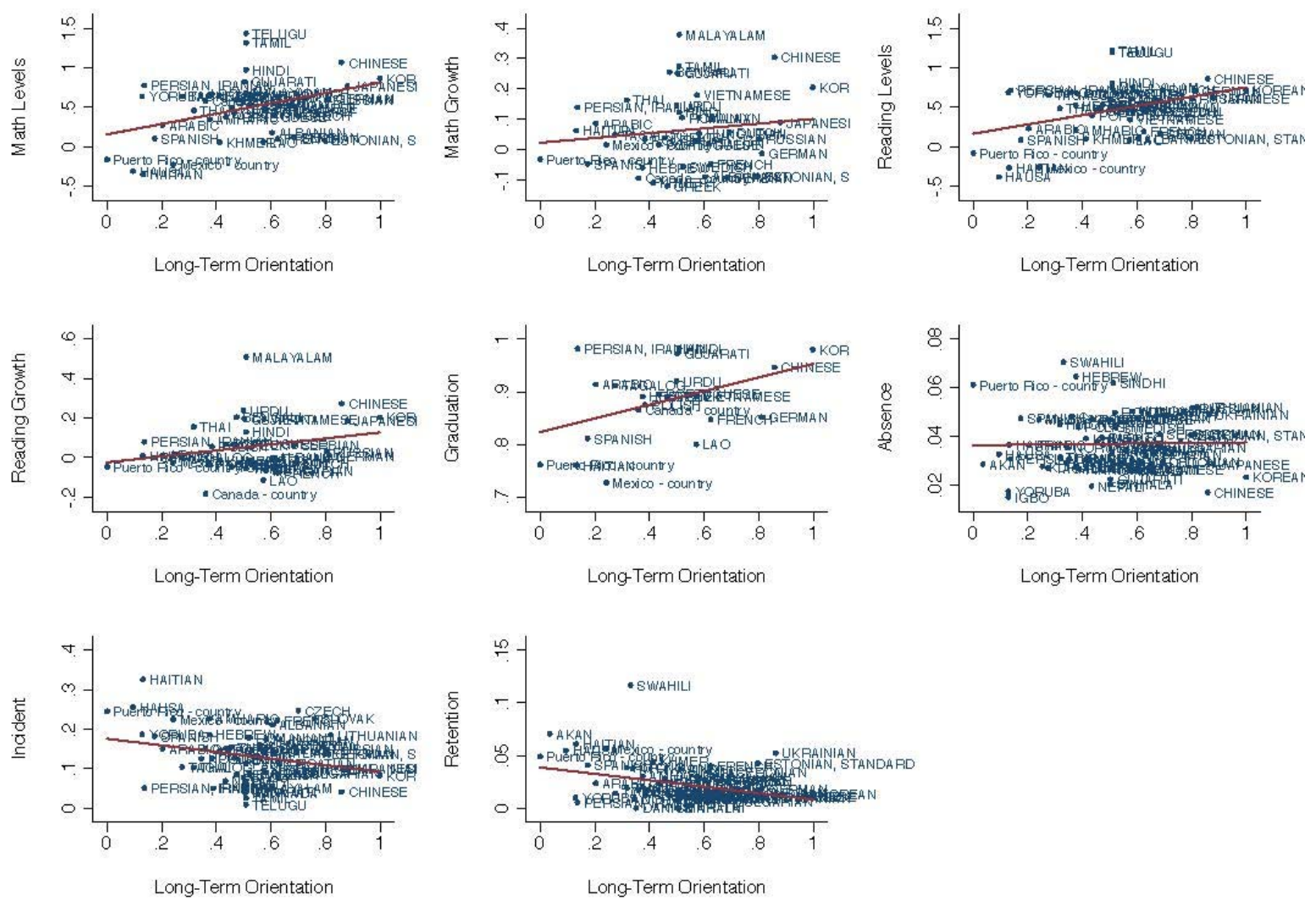

For purposes of confidentiality, we only show data points for languages where we observe at least 50 individuals. 
Figure 4

Long-Term Orientation and educational outcomes, bin-scatters, FLDOE First generation immigrants
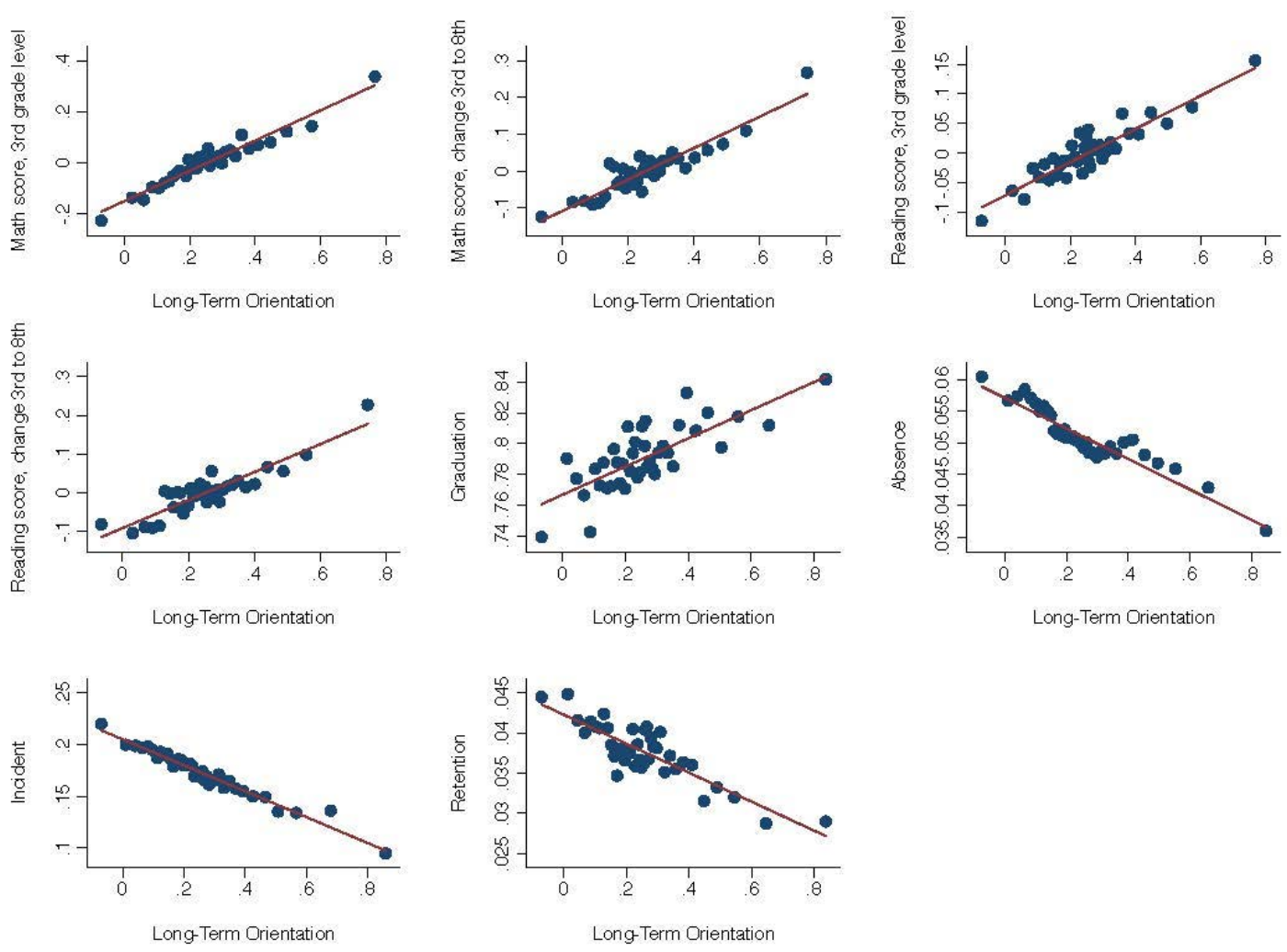
Figure 5

Long-Term Orientation and educational outcomes, bin-scatters, FLDOE Second generation immigrants
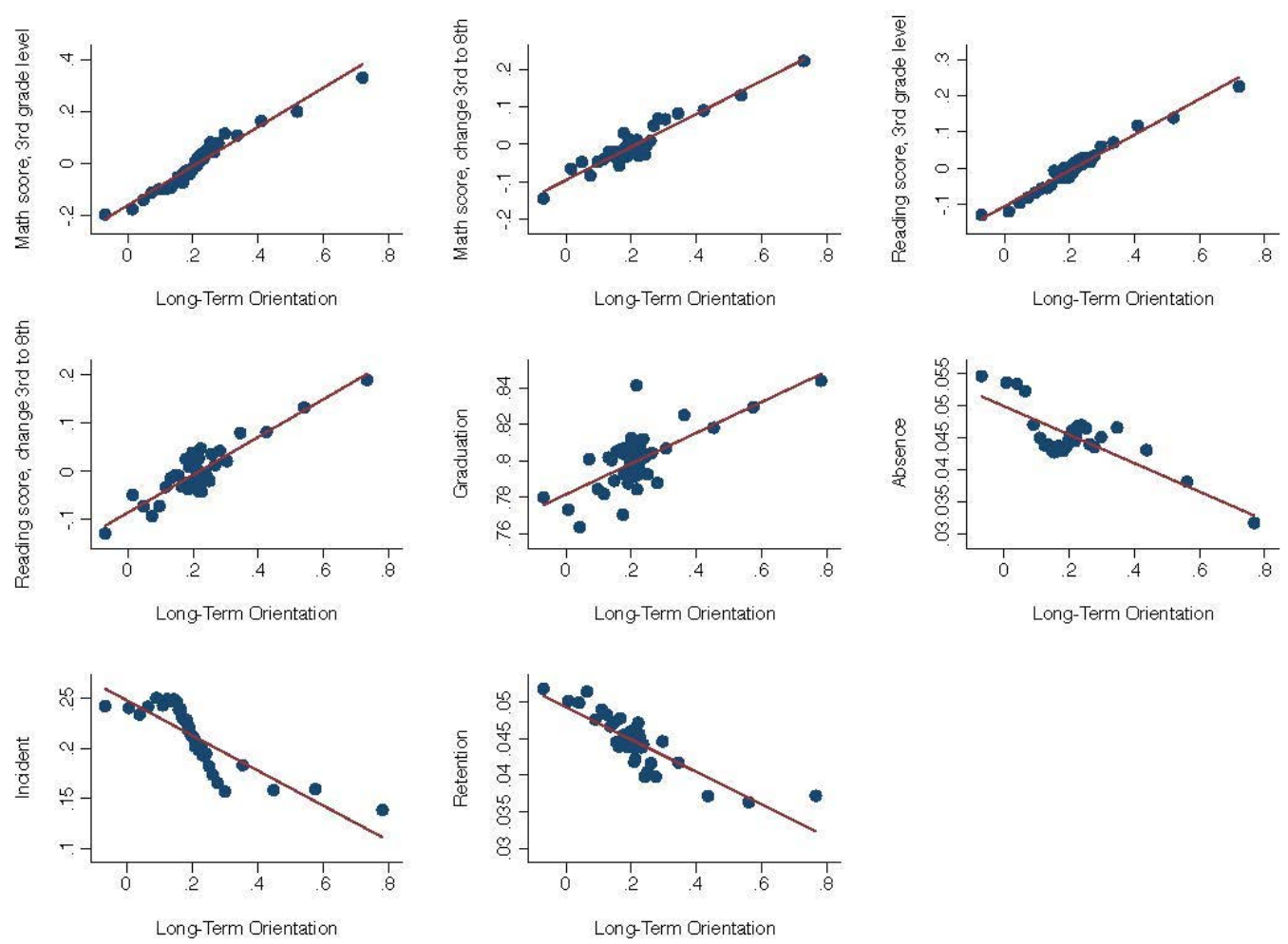
Figure 6A

Long-Term Orientation and educational outcomes, FLDOE

Native, First and Second Generation immigrants

1st generation vs. 2nd generation vs. Natives and Natives (White)
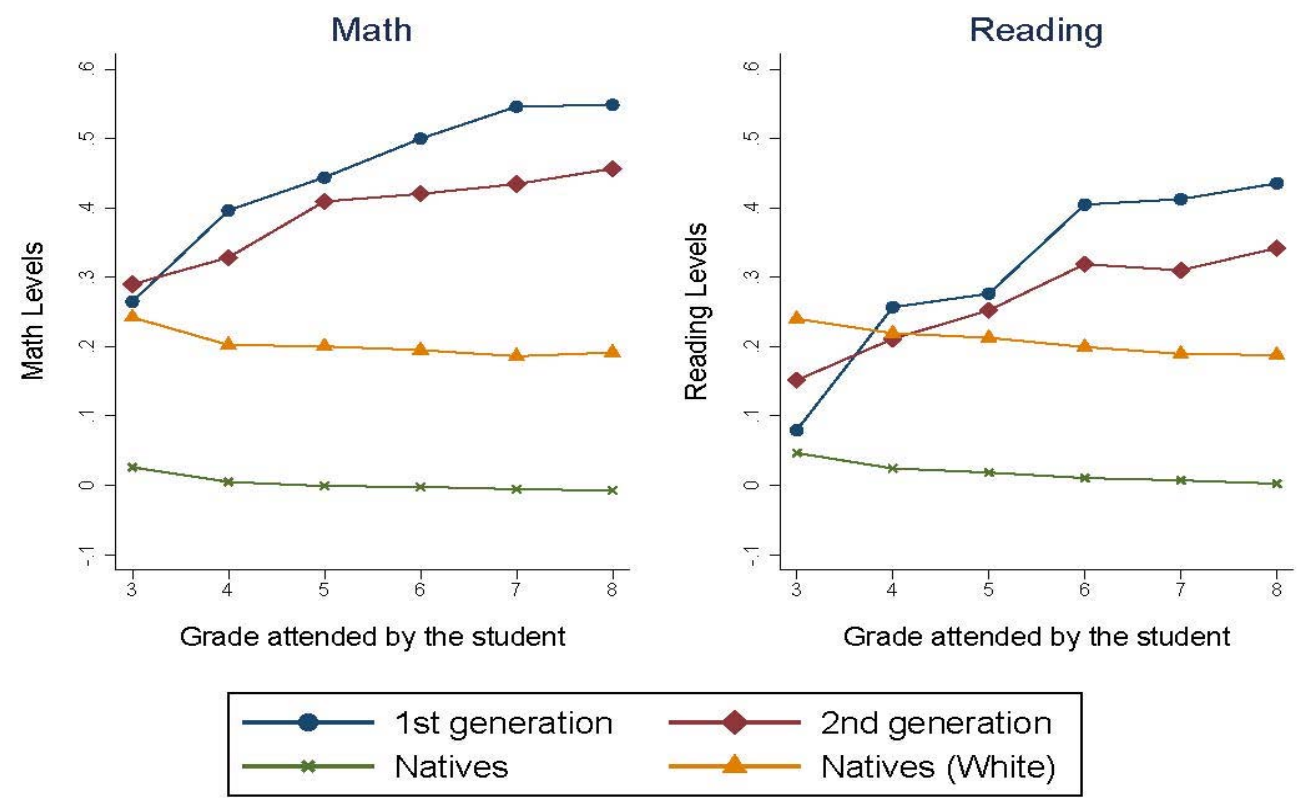

Figure 6B

Long-Term Orientation and educational outcomes, FLDOE Native, First and Second generation immigrants, Grade A Schools

1st generation vs. 2nd generation vs. Natives (White) and Natives - Grade A schools
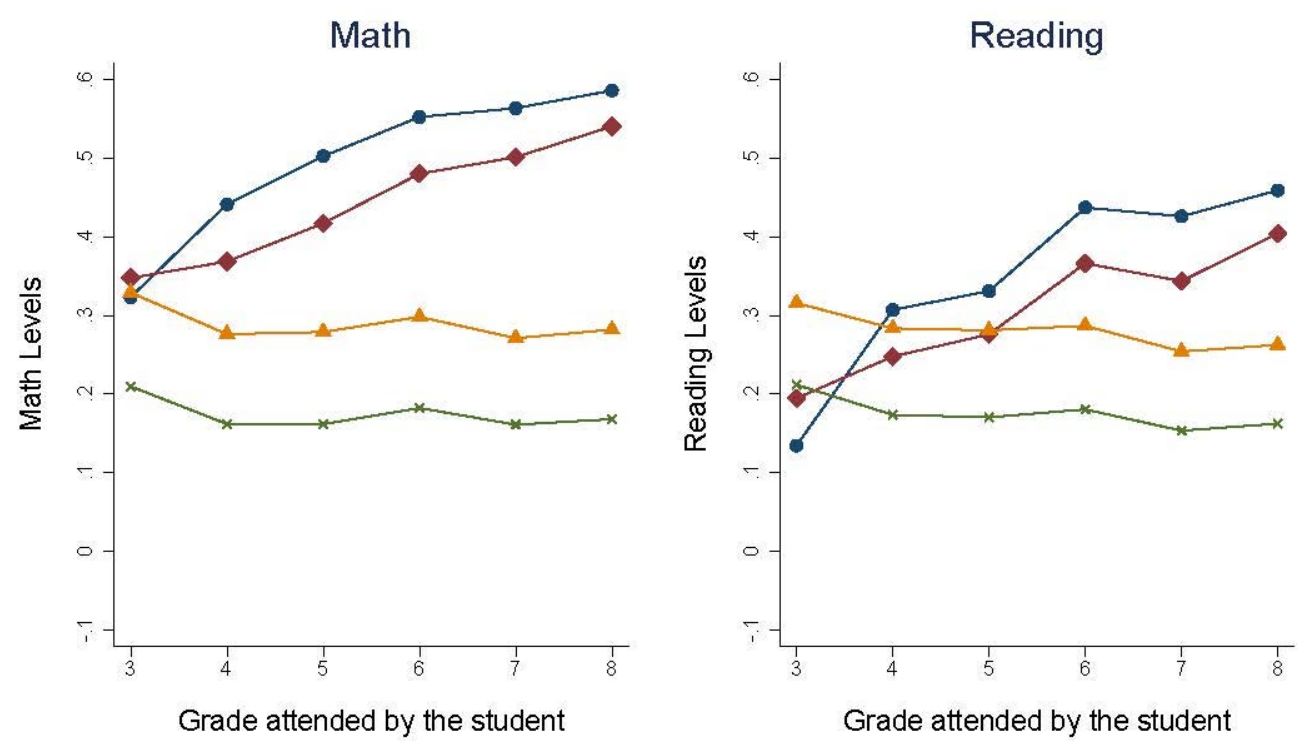

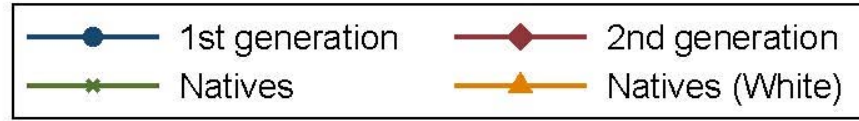


Figure 7

Long-Term Orientation and educational outcomes, FLDOE by Long-Term Orientation quartiles

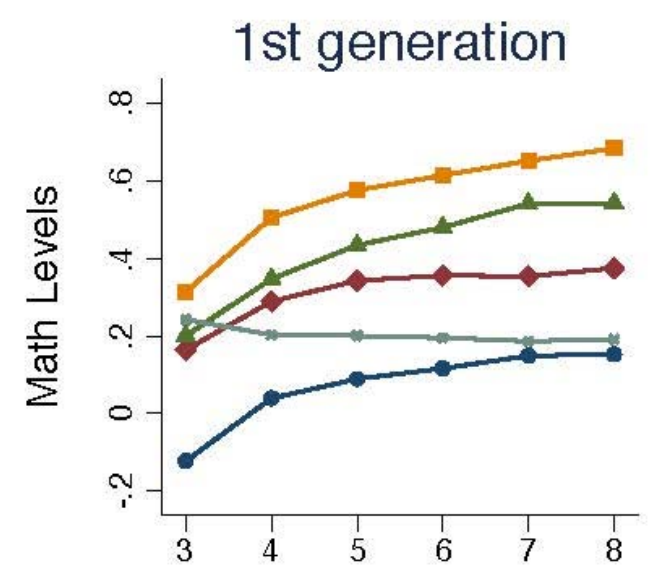

Grade attended by the student

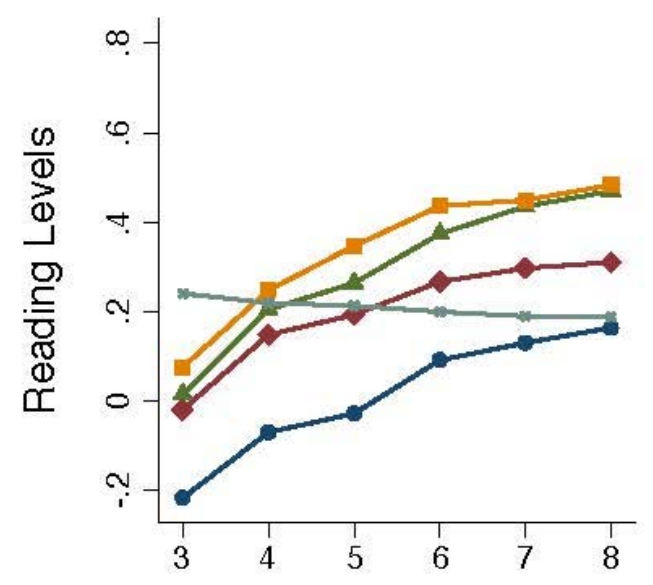

Grade attended by the student

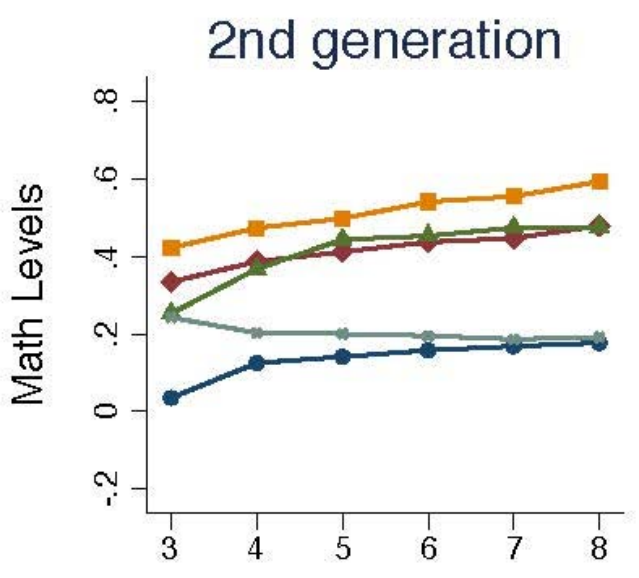

Grade attended by the student

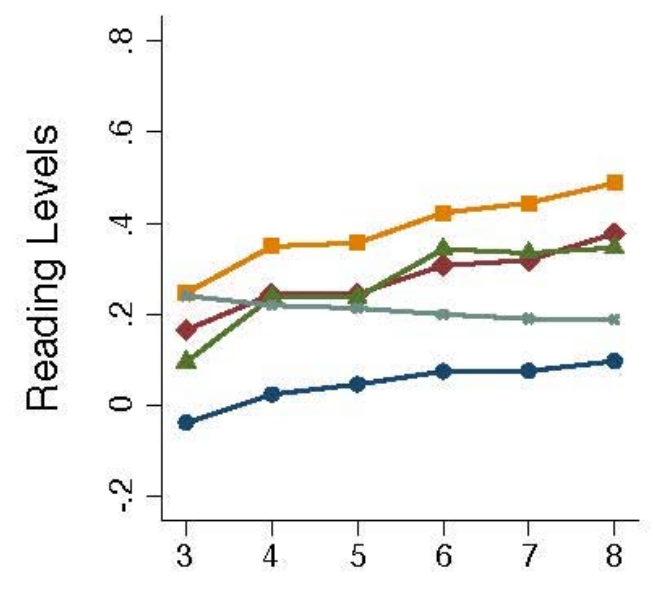

Grade attended by the student

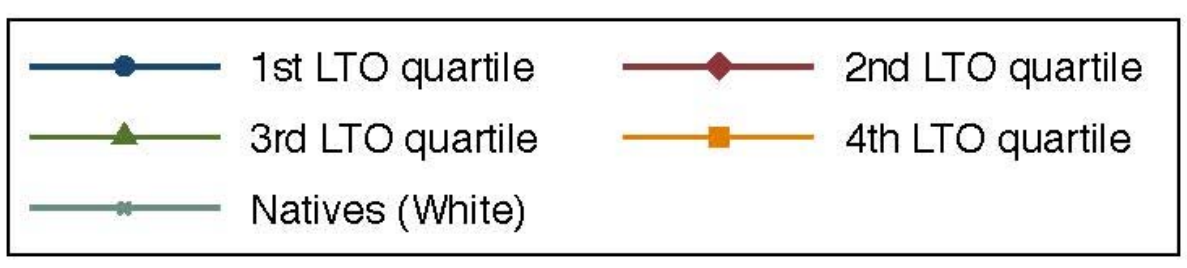


Figure 8

Long-Term Orientation and educational outcomes, raw correlations, PISA First generation immigrants
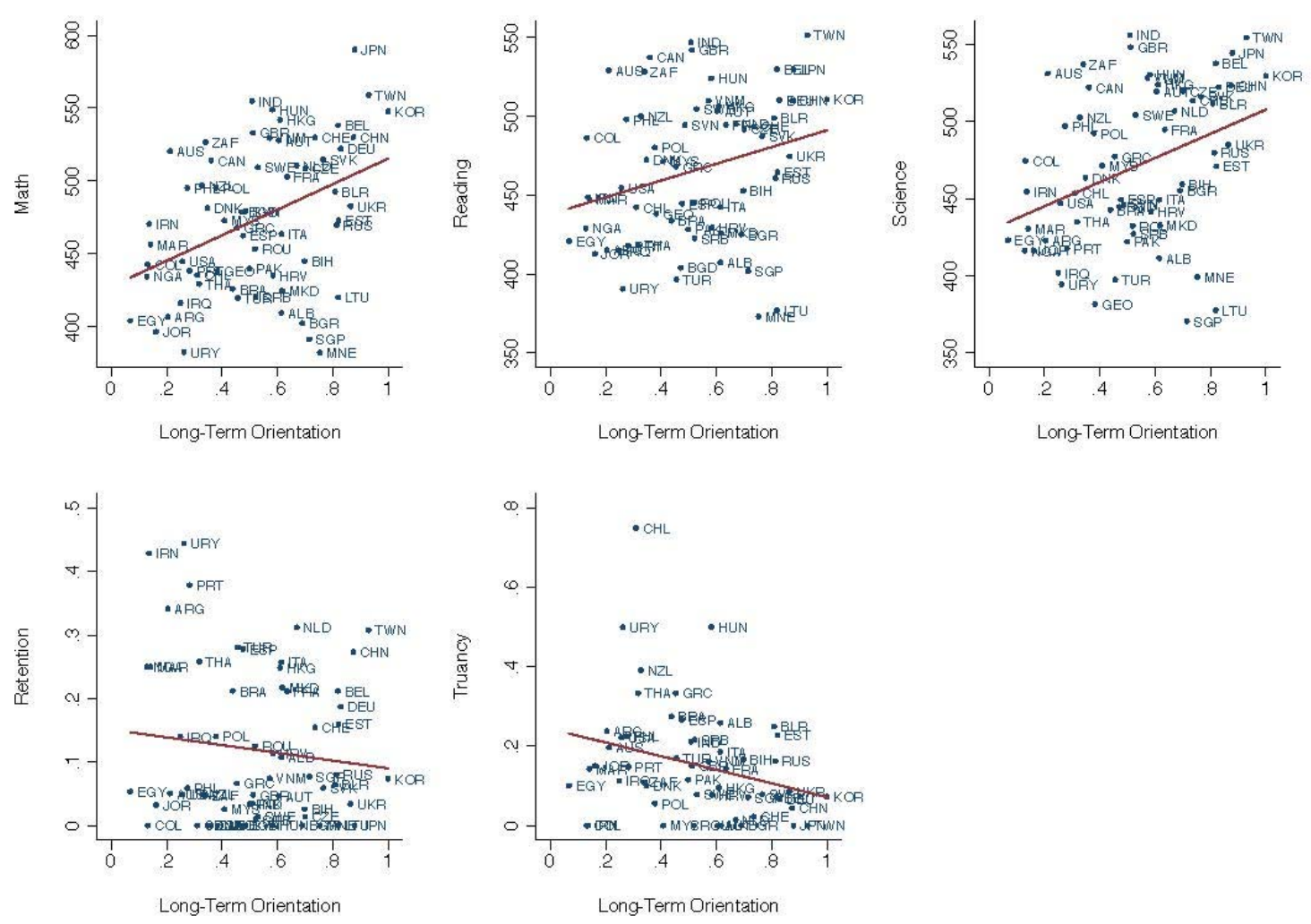
Figure 9

Long-Term Orientation and educational outcomes, raw correlations, PISA Second generation immigrants (maternal side)
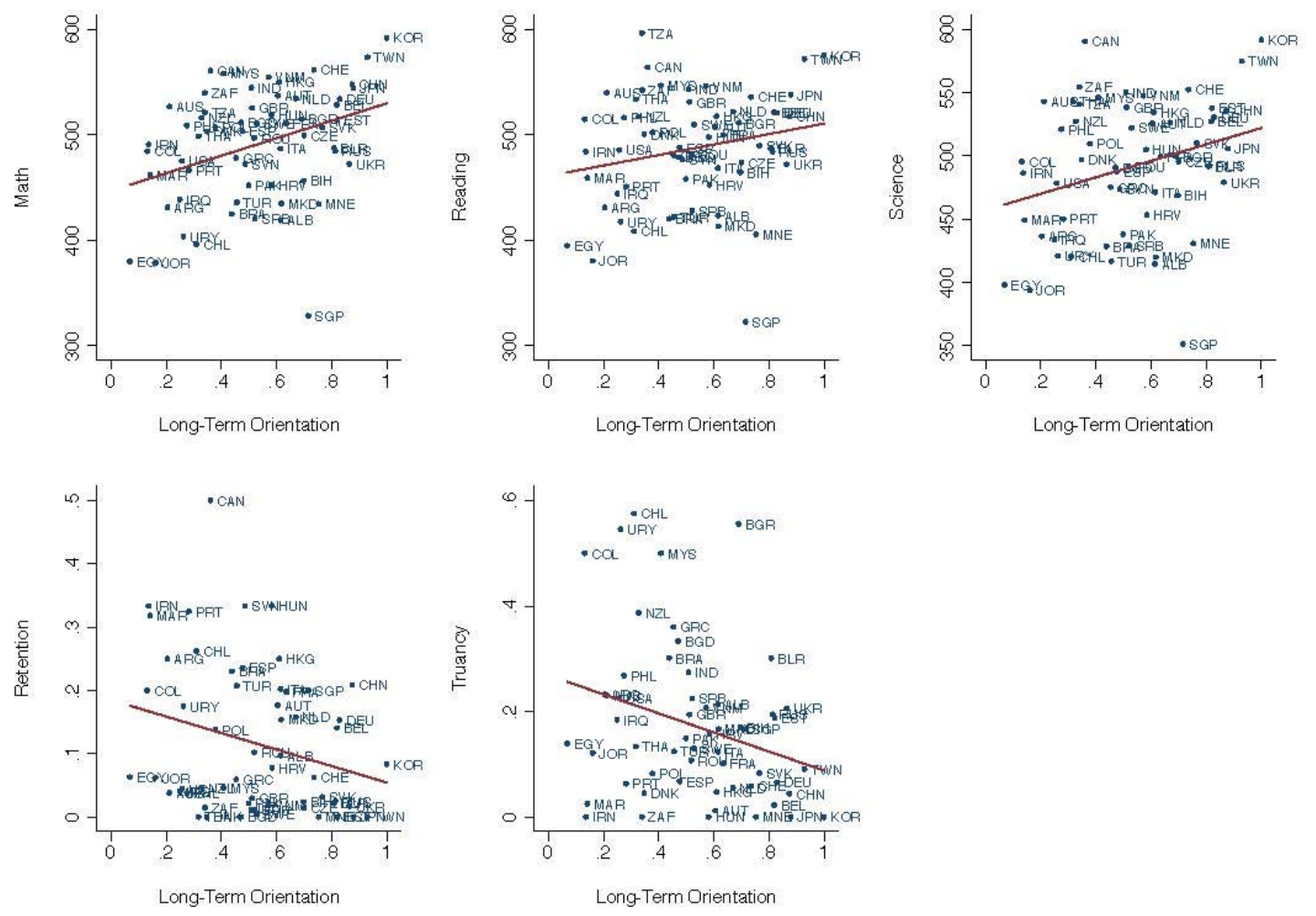
Figure 10

Long-Term Orientation and educational outcomes, bin-scatters, PISA First generation immigrants
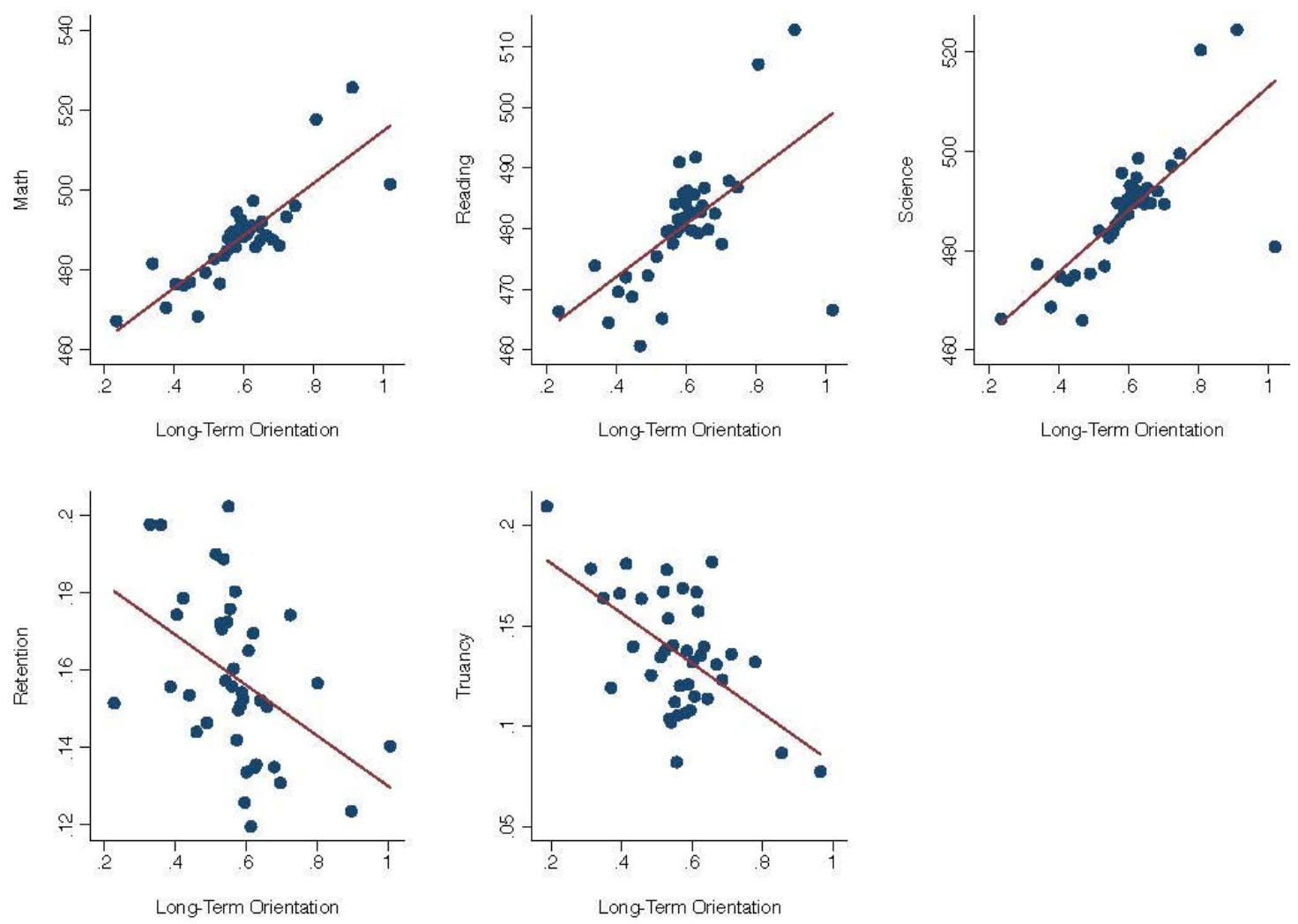
Figure 11

Long-Term Orientation and educational outcomes, bin-scatters, PISA Second generation immigrants (maternal side)
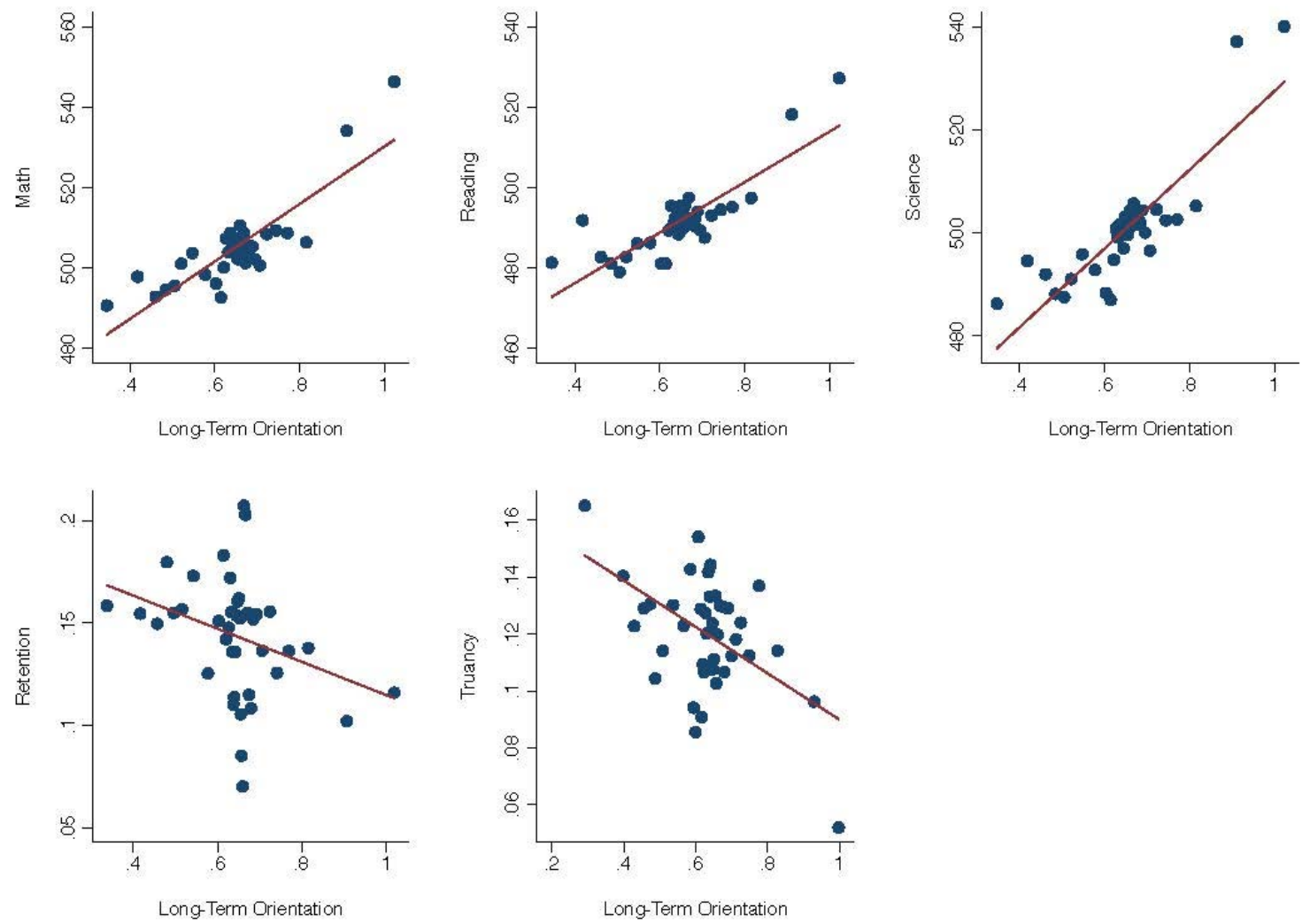
Table 1

Descriptive statistics, Florida Department of Education Dataset

\begin{tabular}{|c|c|c|c|c|c|c|c|c|c|}
\hline \multicolumn{10}{|c|}{ PANEL A } \\
\hline & \multicolumn{3}{|c|}{ 1st generation } & \multicolumn{3}{|c|}{ 2nd generation (extended definition) } & \multicolumn{3}{|c|}{ 2nd generation } \\
\hline & Obs. & Mean & St. dev. & Obs. & Mean & St. dev. & Obs. & Mean & St. dev. \\
\hline Long-Term Orientation* & 724,946 & 0.257 & 0.200 & $2,166,731$ & 0.207 & 0.141 & $1,023,304$ & 0.213 & 0.154 \\
\hline Math score, 3rd grade & 69,652 & 0.000 & 1.000 & 305,382 & 0.000 & 1.000 & 160,763 & 0.000 & 1.000 \\
\hline Math score, change 3 rd to 8 th & 28,046 & 0.000 & 0.783 & 107,053 & 0.000 & 0.775 & 55,880 & 0.000 & 0.773 \\
\hline Reading score, 3rd grade & 69,600 & 0.000 & 1.000 & 305,358 & 0.000 & 1.000 & 160,756 & 0.000 & 1.000 \\
\hline Reading score, change 3 rd to 8 th & 27,931 & 0.000 & 0.843 & 106,543 & 0.000 & 0.813 & 55,586 & 0.000 & 0.803 \\
\hline Graduation & 24,067 & 0.791 & 0.407 & 57,130 & 0.769 & 0.421 & 25,684 & 0.800 & 0.400 \\
\hline$\%$ Absent Days & 724,946 & 0.051 & 0.070 & $2,166,731$ & 0.053 & 0.071 & $1,023,304$ & 0.045 & 0.063 \\
\hline Disciplinary Incident & 451,227 & 0.173 & 0.378 & $1,163,755$ & 0.227 & 0.419 & 524,262 & 0.211 & 0.408 \\
\hline Retention & 579,293 & 0.038 & 0.190 & $1,771,660$ & 0.046 & 0.210 & 844,819 & 0.045 & 0.206 \\
\hline Male* & 724,946 & 0.512 & 0.500 & $2,166,731$ & 0.510 & 0.500 & $1,023,304$ & 0.505 & 0.500 \\
\hline Age in months* & 724,946 & 148.449 & 31.452 & $2,166,731$ & 142.709 & 30.895 & $1,023,304$ & 141.271 & 30.739 \\
\hline Special education* & 724,946 & 0.080 & 0.271 & $2,166,731$ & 0.143 & 0.350 & $1,023,304$ & 0.136 & 0.343 \\
\hline Free or Reduced Priced Lunch* & 724,946 & 0.610 & 0.488 & $2,166,731$ & 0.709 & 0.454 & $1,023,304$ & 0.725 & 0.446 \\
\hline Enrolled in Limited English proficiency program* & 724,946 & 0.333 & 0.471 & $2,166,731$ & 0.159 & 0.366 & $1,023,304$ & 0.127 & 0.333 \\
\hline Enrolled in Limited English proficiency in grade 3 & 28,046 & 0.417 & 0.493 & 107,053 & 0.217 & 0.412 & 55,880 & 0.211 & 0.408 \\
\hline Log GDP pc year 2000 ppp & 69,649 & 3.182 & 0.683 & 304,449 & 3.128 & 0.450 & 160,241 & 3.112 & 0.531 \\
\hline Distance from the US (log) & 69,652 & 8.390 & 0.591 & 305,382 & 8.260 & 0.422 & 160,763 & 8.232 & 0.494 \\
\hline Savings over GDP/100 & 69,637 & 0.215 & 0.084 & 304,522 & 0.209 & 0.043 & 160,331 & 0.205 & 0.050 \\
\hline Education selection to Florida & 69,031 & 0.427 & 0.247 & 295,119 & 0.427 & 0.173 & 155,048 & 0.437 & 0.225 \\
\hline Mean PISA score in Math & 54,535 & 4.107 & 0.477 & 54,797 & 4.300 & 0.493 & 46,963 & 4.252 & 0.454 \\
\hline Mother high school graduate & - & - & - & 184,331 & 0.340 & 0.474 & - & - & - \\
\hline Mother attended some college & - & - & & 184,331 & 0.173 & 0.378 & - & - & - \\
\hline Mother 4yr college graduate & & & & 184,331 & 0.136 & 0.342 & & & \\
\hline Mother teen pregnancy & - & - & & 184,331 & 0.010 & 0.099 & - & - & - \\
\hline Mother married at time of birth & - & - & & 184,331 & 0.630 & 0.483 & - & - & - \\
\hline Number of older siblings & - & - & & 184,331 & 1.050 & 1.221 & - & - & - \\
\hline Median income in zipcode of birth $(100,000$ of $\$)$ & - & - & & 184,331 & 42,199 & 13,764 & - & - & - \\
\hline
\end{tabular}

\begin{tabular}{lccc}
\hline \multicolumn{4}{c}{ PANEL B } \\
\hline \multicolumn{4}{c}{ 1st generation + 2nd generation (extended definition) } \\
\hline Fraction speaking the same language (log)* & Mean & St. dev. \\
Fraction of advanced classes & 384,139 & -0.709 & 1.255 \\
Fraction of advanced classes (scientific subjects) & 512,070 & 0.058 & 0.145 \\
Math score, 8th grade & 512,070 & 0.013 & 0.054 \\
School Letter Score (from A to F) at t-1, (pre-) & 512,070 & 0.042 & 0.982 \\
kindergarten & 243,233 & 4.119 & 0.991 \\
School Letter Score (from A to F) at t-1, all grades & $3,478,545$ & 4.128 & 1.012 \\
Gifted in grade 4 & 26,308 & 0.112 & 0.316 \\
Futureless Language (Chen)* & $1,942,897$ & 0.019 & 0.135 \\
Maximum Crop Yield (Galor)* & 373,220 & 8.593 & 2.298 \\
\hline \hline
\end{tabular}

Notes. The table reports sample statistics for the FLDOE sample and various country of origin level controls. All the variables, as well as the definitions of first and second generation immigrants are described in details in the text and the Online Appendix. The statistics marked with an asterisk $(*)$ are calculated based on the sample used to run the regressions with the dependent variable "\% Absent Days" (i.e., the specification where the largest sample is used). The statistics for the variable "Enrolled in Limited English proficiency in grade 3" are calculated based on the sample used to run the regression on the variable "Math score, change 3 rd to $8^{\text {th" }}$. 
Table 2

\section{Long-Term Orientation and school performance in mathematics, FLDOE First generation immigrants}

\begin{tabular}{|c|c|c|c|c|c|c|c|c|}
\hline \multirow[b]{4}{*}{ VARIABLES } & \multicolumn{8}{|c|}{ Sample: 1 st generation } \\
\hline & \multicolumn{4}{|c|}{ Whole sample } & \multicolumn{4}{|c|}{ Language restriction } \\
\hline & (1) & (2) & (3) & (4) & (5) & (6) & $(7)$ & (8) \\
\hline & $\begin{array}{c}\text { Math } \\
3 \mathrm{rd} \xi\end{array}$ & $\begin{array}{l}\text { score, } \\
\text { grade }\end{array}$ & $\begin{array}{r}\text { Math } \\
\text { change } 3 \\
\end{array}$ & $\begin{array}{l}\text { score, } \\
3 \text { rd to } 8 \text { th }\end{array}$ & $\begin{array}{r}\text { Math } \\
3 \text { rd }\end{array}$ & $\begin{array}{l}\text { score, } \\
\text { grade }\end{array}$ & $\begin{array}{r}\text { Math } \\
\text { change } 3 r\end{array}$ & $\begin{array}{l}\text { score, } \\
\text { 3rd to 8th }\end{array}$ \\
\hline Long-Term Orientation & $\begin{array}{c}0.597 * * * \\
(0.136)\end{array}$ & $\begin{array}{c}0.336^{* * *} \\
(0.123)\end{array}$ & $\begin{array}{c}0.217^{* *} \\
(0.100)\end{array}$ & $\begin{array}{c}0.217^{* *} \\
(0.091)\end{array}$ & $\begin{array}{c}0.814 * * * \\
(0.145)\end{array}$ & $\begin{array}{c}0.591 * * * \\
(0.135)\end{array}$ & $\begin{array}{c}0.454 * * * \\
(0.119)\end{array}$ & $\begin{array}{c}0.427 * * * \\
(0.111)\end{array}$ \\
\hline Male & $\begin{array}{c}0.081 * * * \\
(0.009)\end{array}$ & $\begin{array}{c}0.121^{* * *} \\
(0.006)\end{array}$ & $\begin{array}{l}-0.015 \\
(0.010)\end{array}$ & $\begin{array}{l}-0.003 \\
(0.010)\end{array}$ & $\begin{array}{c}0.078^{* * *} \\
(0.011)\end{array}$ & $\begin{array}{c}0.116^{* * *} \\
(0.007)\end{array}$ & $\begin{array}{l}-0.006 \\
(0.008)\end{array}$ & $\begin{array}{c}0.007 \\
(0.008)\end{array}$ \\
\hline Age in months & $\begin{array}{c}-0.016^{* * *} \\
(0.001)\end{array}$ & $\begin{array}{c}-0.005^{* * *} \\
(0.001)\end{array}$ & $\begin{array}{c}-0.020^{* * *} * \\
(0.001)\end{array}$ & $\begin{array}{c}-0.017 * * * \\
(0.001)\end{array}$ & $\begin{array}{c}-0.014^{* * *} \\
(0.001)\end{array}$ & $\begin{array}{c}-0.004^{* * *} \\
(0.001)\end{array}$ & $\begin{array}{c}-0.020^{* * *} \\
(0.002)\end{array}$ & $\begin{array}{c}-0.017 * * * \\
(0.001)\end{array}$ \\
\hline Free or Reduced Priced Lunch & & $\begin{array}{c}-0.202^{* * *} \\
(0.019)\end{array}$ & & $\begin{array}{c}-0.069^{* * *} \\
(0.013)\end{array}$ & & $\begin{array}{c}-0.191 * * * \\
(0.017)\end{array}$ & & $\begin{array}{c}-0.068^{* * *} \\
(0.014)\end{array}$ \\
\hline Special education & & $\begin{array}{c}-0.674 * * * \\
(0.029)\end{array}$ & & $\begin{array}{c}-0.353^{* * *} \\
(0.022)\end{array}$ & & $\begin{array}{c}-0.654^{* * *} \\
(0.030)\end{array}$ & & $\begin{array}{c}-0.352^{* * *} \\
(0.023)\end{array}$ \\
\hline Enrolled in Limited English proficiency program & & $\begin{array}{c}-0.660^{* * *} \\
(0.026)\end{array}$ & & & & $\begin{array}{c}-0.671^{* * *} \\
(0.026)\end{array}$ & & \\
\hline Enrolled in Limited English proficiency in grade 3 & & & & $\begin{array}{c}0.120^{* * *} \\
(0.020)\end{array}$ & & & & $\begin{array}{c}0.099 * * * \\
(0.019)\end{array}$ \\
\hline Math score, 3rd grade & & & $\begin{array}{c}-0.348^{* * *} \\
(0.015)\end{array}$ & $\begin{array}{c}-0.357 * * * \\
(0.017)\end{array}$ & & & $\begin{array}{c}-0.360^{* * *} \\
(0.014)\end{array}$ & $\begin{array}{c}-0.370^{* * *} \\
(0.016)\end{array}$ \\
\hline Observations & 81,986 & 81,977 & 32,895 & 32,895 & 69,659 & 69,652 & 28,046 & 28,046 \\
\hline R-squared & 0.337 & 0.441 & 0.386 & 0.399 & 0.353 & 0.458 & 0.405 & 0.417 \\
\hline Year*school FE & YES & YES & YES & YES & YES & YES & YES & YES \\
\hline Dependent Variable (mean) & 0.000 & 0.000 & 0.000 & 0.000 & 0.000 & 0.000 & 0.000 & 0.000 \\
\hline Dependent Variable (sd) & 1.000 & 1.000 & 0.779 & 0.779 & 1.000 & 1.000 & 0.783 & 0.783 \\
\hline Long-Term Orientation (mean) & 0.307 & 0.307 & 0.304 & 0.304 & 0.255 & 0.255 & 0.254 & 0.254 \\
\hline Long-Term Orientation (sd) & 0.241 & 0.241 & 0.236 & 0.236 & 0.192 & 0.192 & 0.190 & 0.190 \\
\hline Long-Term Orientation (beta) & 0.144 & 0.081 & 0.066 & 0.066 & 0.156 & 0.113 & 0.110 & 0.103 \\
\hline N_clust & 93 & 93 & 90 & 90 & 89 & 89 & 84 & 84 \\
\hline
\end{tabular}

Notes. The table reports OLS estimates, with standard errors clustered at the country level. The unit of observation is a student born between 1992 and 2002 and observed during the academic years 2002-2012. In columns 1-4, the sample includes first generation immigrants defined using the information on the country of origin. In columns 5-8, the sample includes first generation immigrants defined using both the information on the country of origin and the language spoken at home (see online Appendix for details). The dependent variables are: students' Florida Comprehensive Assessment Test math score in grade 3 (standardized with mean 0 and variance 1) and the change in math score from grade 3 to grade 8. Individual controls are: age in months, a male dummy, an indicator variable for free or reduced free lunch eligibility, a dummy indicating if the student is enrolled in a limited English proficiency program and indicator for special education needs. Columns 3-4, 7-8 also control for the math score in grade 3. The "Long Term Orientation" variable is based on Hofstede (2010) and is measured on a 0-1 scale. We describe in details all the variables in the online Appendix. ***, **, and $*$ indicate significance at the $1 \%, 5 \%$, and $10 \%$ levels. 
Table 3

Long-Term Orientation and additional educational outcomes, FLDOE First generation immigrants

\begin{tabular}{|c|c|c|c|c|c|c|}
\hline VARIABLES & $\begin{array}{l}\text { (1) } \\
\text { Reading score, } \\
\text { 3rd grade }\end{array}$ & $\begin{array}{c}(2) \\
\text { Reading score, } \\
\text { change 3rd to } 8 \text { th }\end{array}$ & $\begin{array}{c}\text { (3) } \\
\text { Graduation }\end{array}$ & $\begin{array}{c}\text { (4) } \\
\% \text { Absent } \\
\text { Days }\end{array}$ & $\begin{array}{c}(5) \\
\text { Disciplinary } \\
\text { Incident }\end{array}$ & $\begin{array}{c}\text { (6) } \\
\text { Retention }\end{array}$ \\
\hline Long-Term Orientation & $\begin{array}{c}0.281 * * * \\
(0.086)\end{array}$ & $\begin{array}{c}0.362^{* * *} \\
(0.116)\end{array}$ & $\begin{array}{c}0.092 * * * \\
(0.031)\end{array}$ & $\begin{array}{c}-0.024 * * * \\
(0.008)\end{array}$ & $\begin{array}{c}-0.125^{* * *} \\
(0.023)\end{array}$ & $\begin{array}{c}-0.018 * * * \\
(0.006)\end{array}$ \\
\hline Male & $\begin{array}{c}-0.055^{\text {*** }} \\
(0.007)\end{array}$ & $\begin{array}{c}-0.042^{* * *} \\
(0.011)\end{array}$ & $\begin{array}{c}-0.033^{* * *} \\
(0.004)\end{array}$ & $\begin{array}{c}-0.002^{* * *} \\
(0.000)\end{array}$ & $\begin{array}{c}0.090^{* * *} \\
(0.006)\end{array}$ & $\begin{array}{c}0.011 * * * \\
(0.001)\end{array}$ \\
\hline Age in months & $\begin{array}{c}-0.005^{\text {*** }} \\
(0.001)\end{array}$ & $\begin{array}{c}-0.012^{\text {*** }} \\
(0.002)\end{array}$ & $\begin{array}{c}-0.004^{* * *} \\
(0.001)\end{array}$ & $\begin{array}{c}0.001 * * * \\
(0.000)\end{array}$ & $\begin{array}{c}0.005^{* * *} \\
(0.000)\end{array}$ & $\begin{array}{c}-0.000^{* * *} \\
(0.000)\end{array}$ \\
\hline Free or Reduced Priced Lunch & $\begin{array}{c}-0.200^{* * *} \\
(0.016)\end{array}$ & $\begin{array}{c}-0.109^{* * *} \\
(0.017)\end{array}$ & $\begin{array}{c}0.002 \\
(0.009)\end{array}$ & $\begin{array}{l}-0.003 \\
(0.002)\end{array}$ & $\begin{array}{c}0.039^{* * *} \\
(0.005)\end{array}$ & $\begin{array}{c}0.005^{* * *} \\
(0.001)\end{array}$ \\
\hline Special education & $\begin{array}{c}-0.676^{* * *} \\
(0.018)\end{array}$ & $\begin{array}{c}-0.436^{* * *} \\
(0.029)\end{array}$ & $\begin{array}{c}-0.203^{* * *} \\
(0.023)\end{array}$ & $\begin{array}{c}0.009 * * * \\
(0.002)\end{array}$ & $\begin{array}{c}0.059 * * * \\
(0.003)\end{array}$ & $\begin{array}{c}0.032^{* * *} \\
(0.005)\end{array}$ \\
\hline Enrolled in Limited English proficiency program & $\begin{array}{c}-0.839 \text { *** } \\
(0.022)\end{array}$ & & $\begin{array}{c}-0.393^{* * *} \\
(0.015)\end{array}$ & $\begin{array}{c}0.007 * * * \\
(0.001)\end{array}$ & $\begin{array}{c}0.010^{* *} \\
(0.005)\end{array}$ & $\begin{array}{c}0.035^{* * *} \\
(0.003)\end{array}$ \\
\hline Enrolled in Limited English proficiency in grade 3 & & $\begin{array}{c}0.035 \\
(0.023)\end{array}$ & & & & \\
\hline Reading score, 3rd grade & & $\begin{array}{c}-0.446 * * * \\
(0.016)\end{array}$ & & & & \\
\hline Observations & 69,600 & 27,931 & 24,067 & 724,946 & 451,227 & 579,293 \\
\hline R-squared & 0.473 & 0.426 & 0.383 & 0.185 & 0.123 & 0.114 \\
\hline Year*school FE & YES & YES & YES & YES & YES & YES \\
\hline Grade FE & - & - & - & YES & YES & YES \\
\hline Dependent Variable (mean) & 0.000 & 0.000 & 0.791 & 0.051 & 0.173 & 0.038 \\
\hline Dependent Variable (sd) & 1.000 & 0.843 & 0.407 & 0.070 & 0.378 & 0.190 \\
\hline Long-Term Orientation (mean) & 0.255 & 0.254 & 0.262 & 0.257 & 0.259 & 0.256 \\
\hline Long-Term Orientation (sd) & 0.192 & 0.189 & 0.203 & 0.200 & 0.202 & 0.197 \\
\hline Long-Term Orientation (beta) & 0.054 & 0.081 & 0.046 & -0.069 & -0.067 & -0.019 \\
\hline N_clust & 89 & 84 & 88 & 92 & 92 & 92 \\
\hline
\end{tabular}

Notes. The table reports OLS estimates, with standard errors clustered at the country level. The unit of observation is a student born between 1992 and 2002 and observed during the academic years 2002-2012. The sample includes first generation immigrants defined using the information on the country of origin and the language spoken at home. The dependent variables are: students' Florida Comprehensive Assessment Test reading score in grade 3 (standardized with mean 0 and variance 1), the change in reading score from grade 3 to grade 8 , high school graduation (a dummy for whether the student received a standard diploma within four years after entering the $9^{\text {th }}$ grade for the first time), absence rates (the percentage of days in which the student is absent during the academic year) and retention (an indicator for whether the student repeats the same grade at least once) measured in grades 3-12, and disciplinary incidents (a dummy for whether the student was involved in a disciplinary incident defined as serious offences often leading to suspension) measured in grades 6-12. Individual controls are the same as in Table 2. In column 2 we also control for the reading score in grade 3. The "Long Term Orientation" variable is based on Hofstede (2010) and is measured on a 0-1 scale. We describe in details all the variables in the online Appendix. ***, **, and * indicate significance at the $1 \%, 5 \%$, and $10 \%$ levels. 
Table 4

Long-Term Orientation and educational performance, FLDOE Second generation immigrants

\begin{tabular}{|c|c|c|c|c|c|c|c|c|}
\hline VARIABLES & $\begin{array}{c}\text { (1) } \\
\text { Math score, } \\
\text { 3rd grade }\end{array}$ & $\begin{array}{c}\text { (2) } \\
\text { Math score, } \\
\text { change 3rd to 8th }\end{array}$ & $\begin{array}{c}\text { (3) } \\
\text { Reading score, } \\
\text { 3rd grade }\end{array}$ & $\begin{array}{c}\text { (4) } \\
\text { Reading score, } \\
\text { change 3rd to 8th }\end{array}$ & $\begin{array}{c}\text { (5) } \\
\text { Graduation }\end{array}$ & $\begin{array}{c}(6) \\
\% \text { Absent } \\
\text { Days } \\
\end{array}$ & $\begin{array}{c}(7) \\
\text { Disciplinary } \\
\text { Incident } \\
\end{array}$ & $\begin{array}{c}\text { (8) } \\
\text { Retention }\end{array}$ \\
\hline Long-Term Orientation & $\begin{array}{c}0.752 * * * \\
(0.131)\end{array}$ & $\begin{array}{c}0.441 * * * \\
(0.109)\end{array}$ & $\begin{array}{c}0.494 * * * \\
(0.078)\end{array}$ & $\begin{array}{c}0.390 * * * \\
(0.090)\end{array}$ & $\begin{array}{c}0.084 * * * \\
(0.009)\end{array}$ & $\begin{array}{c}-0.022 * * \\
(0.009)\end{array}$ & $\begin{array}{c}-0.175^{* * *} \\
(0.046)\end{array}$ & $\begin{array}{c}-0.022 * * * \\
(0.005)\end{array}$ \\
\hline Male & $\begin{array}{c}0.127^{* * *} \\
(0.024)\end{array}$ & $\begin{array}{c}-0.031^{\text {*** }} \\
(0.008)\end{array}$ & $\begin{array}{c}-0.068^{* * *} \\
(0.017)\end{array}$ & $\begin{array}{c}-0.051 \text { *** } \\
(0.010)\end{array}$ & $\begin{array}{c}-0.049 \text { *** } \\
(0.004)\end{array}$ & $\begin{array}{l}-0.000 \\
(0.000)\end{array}$ & $\begin{array}{c}0.093 * * * \\
(0.006)\end{array}$ & $\begin{array}{c}0.014 * * * \\
(0.002)\end{array}$ \\
\hline Age in months & $\begin{array}{c}-0.012^{* * *} \\
(0.001)\end{array}$ & $\begin{array}{c}-0.018^{* * *} \\
(0.001)\end{array}$ & $\begin{array}{c}-0.014 * * * \\
(0.002)\end{array}$ & $\begin{array}{c}-0.013 * * * \\
(0.001)\end{array}$ & $\begin{array}{c}-0.006^{* * *} \\
(0.001)\end{array}$ & $\begin{array}{c}0.001 * * * \\
(0.000)\end{array}$ & $\begin{array}{c}0.007 * * * \\
(0.000)\end{array}$ & $\begin{array}{c}-0.001 * * * \\
(0.000)\end{array}$ \\
\hline Free or Reduced Priced Lunch & $\begin{array}{c}-0.241^{* * * *} \\
(0.014)\end{array}$ & $\begin{array}{c}-0.056^{* * *} \\
(0.013)\end{array}$ & $\begin{array}{c}-0.245^{* * * *} \\
(0.014)\end{array}$ & $\begin{array}{c}-0.090^{* * *} \\
(0.013)\end{array}$ & $\begin{array}{l}-0.008 \\
(0.007)\end{array}$ & $\begin{array}{c}0.001 \\
(0.002)\end{array}$ & $\begin{array}{c}0.048 * * * \\
(0.006)\end{array}$ & $\begin{array}{c}0.009 * * * \\
(0.001)\end{array}$ \\
\hline Special education & $\begin{array}{c}-0.650^{* * * *} \\
(0.027)\end{array}$ & $\begin{array}{c}-0.234^{* * *} \\
(0.009)\end{array}$ & $\begin{array}{c}-0.739 * * * \\
(0.023)\end{array}$ & $\begin{array}{c}-0.183^{* * *} \\
(0.012)\end{array}$ & $\begin{array}{c}-0.161 \text { **** } \\
(0.003)\end{array}$ & $\begin{array}{c}0.006 * * * \\
(0.000)\end{array}$ & $\begin{array}{c}0.027 * * * \\
(0.003)\end{array}$ & $\begin{array}{c}0.033^{* * * *} \\
(0.001)\end{array}$ \\
\hline Enrolled in Limited English proficiency program & $\begin{array}{c}-0.657^{* * *} \\
(0.019)\end{array}$ & & $\begin{array}{c}-0.727^{* * *} \\
(0.029)\end{array}$ & & $\begin{array}{c}-0.304^{* * * *} \\
(0.019)\end{array}$ & $\begin{array}{c}0.004 * * * \\
(0.001)\end{array}$ & $\begin{array}{c}0.043^{* * *} \\
(0.006)\end{array}$ & $\begin{array}{c}0.069 * * * \\
(0.004)\end{array}$ \\
\hline Enrolled in Limited English proficiency in grade 3 & & $\begin{array}{c}-0.029^{* *} \\
(0.014)\end{array}$ & & $\begin{array}{c}-0.127^{* * *} \\
(0.015)\end{array}$ & & & & \\
\hline Math score, 3 rd grade & & $\begin{array}{c}-0.364 * * * \\
(0.010)\end{array}$ & & & & & & \\
\hline Reading score, 3 rd grade & & & & $\begin{array}{c}-0.414^{* * *} \\
(0.009)\end{array}$ & & & & \\
\hline Observations & 160,763 & 55,880 & 160,756 & 55,586 & 25,684 & $1,023,304$ & 524,262 & 844,819 \\
\hline R-squared & 0.372 & 0.344 & 0.386 & 0.325 & 0.345 & 0.224 & 0.140 & 0.116 \\
\hline Year*school FE & YES & YES & YES & YES & YES & YES & YES & YES \\
\hline Grade FE & - & - & - & - & - & YES & YES & YES \\
\hline Dependent Variable (mean) & 0.000 & 0.000 & 0.000 & 0.000 & 0.800 & 0.045 & 0.211 & 0.045 \\
\hline Dependent Variable (sd) & 1.000 & 0.773 & 1.000 & 0.803 & 0.400 & 0.063 & 0.408 & 0.206 \\
\hline Long-Term Orientation (mean) & 0.215 & 0.218 & 0.215 & 0.218 & 0.216 & 0.213 & 0.213 & 0.213 \\
\hline Long-Term Orientation (sd) & 0.153 & 0.160 & 0.153 & 0.160 & 0.159 & 0.154 & 0.156 & 0.154 \\
\hline Long-Term Orientation (beta) & 0.115 & 0.091 & 0.076 & 0.078 & 0.034 & -0.054 & -0.067 & -0.017 \\
\hline N_clust & 88 & 79 & 88 & 79 & 65 & 88 & 82 & 88 \\
\hline
\end{tabular}

Notes. The table reports OLS estimates, with standard errors clustered at the language/country level. The unit of observation is a student born between 1992 and 2002 and observed during the academic years 2002-2012. The sample includes second generation immigrants (extended definition) defined using the information on the country of origin of the mother when available (Canada, Mexico, and Puerto Rico), or the language spoken at home for the remaining students for which the country of origin of the mother is not available. See details in the text and the appendix for how the matching between language and countries has been implemented. The dependent variables are: students' Florida Comprehensive Assessment Test math score in grade 3 (standardized with mean 0 and variance 1), change in math score from grade 3 to grade 8 , reading score in grade 3 (standardized with mean 0 and variance 1), change in reading score from grade 3 to grade 8 , high school graduation (a dummy for whether the student received a standard diploma within four years after entering $9^{\text {th }}$ grade for the first time), high school graduation (a dummy for whether the student received a standard diploma within four years after entering $9^{\text {th }}$ grade for the first time), absence rates (the percentage of days in which the student is absent during the academic year) disciplinary incidents (a dummy for whether the student was involved in a disciplinary incident defined as serious offences often leading to suspension) measured in grades 6-12, and retention (an indicator for whether the student repeats the same grade at least once) measured in grades 3-12,. Individual controls are the same as in Table 2. Columns 2 and 4 also control for the math score and reading score in grade 3, respectively. The "Long Term Orientation" variable is based on Hofstede (2010) and is measured on a $0-1$ scale. We describe in details all the variables in the online Appendix. ***, **, and * indicate significance at the $1 \%, 5 \%$, and $10 \%$ levels. 
Table 5

Long-Term Orientation and educational performance, FLDOE Second generation immigrants, extended definition

\begin{tabular}{|c|c|c|c|c|c|c|c|c|}
\hline VARIABLES & $\begin{array}{c}\text { (1) } \\
\text { Math score, } \\
\text { 3rd grade }\end{array}$ & $\begin{array}{c}\text { (2) } \\
\text { Math score, } \\
\text { change 3rd to }\end{array}$ & $\begin{array}{c}\text { (3) } \\
\text { Reading score, } \\
\text { 3rd grade }\end{array}$ & $\begin{array}{l}\text { (4) } \\
\text { Reading score, } \\
\text { change } 3 \text { rd to }\end{array}$ & $\begin{array}{c}\text { (5) } \\
\text { Graduation }\end{array}$ & $\begin{array}{c}(6) \\
\% \text { Absent Days }\end{array}$ & $\begin{array}{c}(7) \\
\text { Disciplinary } \\
\text { Incident }\end{array}$ & $\begin{array}{c}(8) \\
\text { Retention }\end{array}$ \\
\hline Long-Term Orientation & $\begin{array}{c}0.769 * * * \\
(0.120)\end{array}$ & $\begin{array}{c}0.494 * * * \\
(0.100)\end{array}$ & $\begin{array}{c}0.502^{* * *} \\
(0.059)\end{array}$ & $\begin{array}{c}0.447 * * * \\
(0.087)\end{array}$ & $\begin{array}{c}0.127 * * * \\
(0.019)\end{array}$ & $\begin{array}{c}-0.026 * * * \\
(0.008)\end{array}$ & $\begin{array}{c}-0.178 * * * \\
(0.037)\end{array}$ & $\begin{array}{c}-0.025 * * * \\
(0.003)\end{array}$ \\
\hline Male & $\begin{array}{c}0.134^{* * *} \\
(0.017)\end{array}$ & $\begin{array}{c}-0.024 * * * \\
(0.007)\end{array}$ & $\begin{array}{c}-0.062^{* * *} \\
(0.013)\end{array}$ & $\begin{array}{c}-0.048^{* * * *} \\
(0.004)\end{array}$ & $\begin{array}{c}-0.043^{* * * *} \\
(0.001)\end{array}$ & $\begin{array}{c}-0.001 * * * \\
(0.000)\end{array}$ & $\begin{array}{c}0.096 * * * \\
(0.002)\end{array}$ & $\begin{array}{c}0.014 * * * \\
(0.001)\end{array}$ \\
\hline Age in months & $\begin{array}{c}-0.012^{* * *} \\
(0.001)\end{array}$ & $\begin{array}{c}-0.019^{* * *} \\
(0.000)\end{array}$ & $\begin{array}{c}-0.013^{* * *} \\
(0.001)\end{array}$ & $\begin{array}{c}-0.014^{* * *} \\
(0.000)\end{array}$ & $\begin{array}{c}-0.006^{* * *} \\
(0.000)\end{array}$ & $\begin{array}{c}0.001 * * * \\
(0.000)\end{array}$ & $\begin{array}{c}0.007 * * * \\
(0.000)\end{array}$ & $\begin{array}{c}-0.000 * * * \\
(0.000)\end{array}$ \\
\hline Free or Reduced Priced Lunch & $\begin{array}{c}-0.240 * * * \\
(0.010)\end{array}$ & $\begin{array}{c}-0.064^{* * *} \\
(0.009)\end{array}$ & $\begin{array}{c}-0.250^{* * *} \\
(0.008)\end{array}$ & $\begin{array}{c}-0.094^{* * *} \\
(0.008)\end{array}$ & $\begin{array}{c}-0.014^{* * *} \\
(0.005)\end{array}$ & $\begin{array}{c}0.002 \\
(0.002)\end{array}$ & $\begin{array}{c}0.056 * * * \\
(0.004)\end{array}$ & $\begin{array}{c}0.010^{* * * *} \\
(0.001)\end{array}$ \\
\hline Special education & $\begin{array}{c}-0.662^{* * *} \\
(0.017)\end{array}$ & $\begin{array}{c}-0.265^{* * *} \\
(0.008)\end{array}$ & $\begin{array}{c}-0.753^{* * *} \\
(0.020)\end{array}$ & $\begin{array}{c}-0.207^{* * *} \\
(0.007)\end{array}$ & $\begin{array}{c}-0.188^{* * *} \\
(0.006)\end{array}$ & $\begin{array}{c}0.007^{* * *} \\
(0.000)\end{array}$ & $\begin{array}{c}0.035^{* * *} \\
(0.002)\end{array}$ & $\begin{array}{c}0.032^{* * *} \\
(0.001)\end{array}$ \\
\hline Enrolled in Limited English proficiency program & $\begin{array}{c}-0.633^{* * * *} \\
(0.005)\end{array}$ & & $\begin{array}{c}-0.709^{* * *} \\
(0.013)\end{array}$ & & $\begin{array}{c}-0.322^{* * *} \\
(0.005)\end{array}$ & $\begin{array}{c}0.007 * * * \\
(0.001)\end{array}$ & $\begin{array}{c}0.038 * * * \\
(0.004)\end{array}$ & $\begin{array}{c}0.052 * * * \\
(0.003)\end{array}$ \\
\hline Enrolled in Limited English proficiency in grade 3 & & $\begin{array}{c}0.017 \\
(0.018)\end{array}$ & & $\begin{array}{c}-0.076^{* * *} \\
(0.018)\end{array}$ & & & & \\
\hline Math score, 3rd grade & & $\begin{array}{c}-0.370^{* * *} \\
(0.007)\end{array}$ & & & & & & \\
\hline Reading score, 3rd grade & & & & $\begin{array}{c}-0.422^{* * *} \\
(0.005)\end{array}$ & & & & \\
\hline Observations & 305,382 & 107,053 & 305,358 & 106,543 & 57,130 & $2,166,731$ & $1,163,755$ & $1,771,660$ \\
\hline R-squared & 0.342 & 0.310 & 0.354 & 0.292 & 0.344 & 0.204 & 0.129 & 0.094 \\
\hline Year*school FE & YES & YES & YES & YES & YES & YES & YES & YES \\
\hline Grade FE & - & - & - & - & - & YES & YES & YES \\
\hline Dependent Variable (mean) & 0.000 & 0.000 & 0.000 & 0.000 & 0.769 & 0.053 & 0.227 & 0.046 \\
\hline Dependent Variable (sd) & 1.000 & 0.775 & 1.000 & 0.813 & 0.421 & 0.071 & 0.419 & 0.210 \\
\hline Long-Term Orientation (mean) & 0.209 & 0.211 & 0.209 & 0.211 & 0.208 & 0.207 & 0.206 & 0.206 \\
\hline Long-Term Orientation (sd) & 0.144 & 0.147 & 0.144 & 0.147 & 0.142 & 0.141 & 0.141 & 0.141 \\
\hline Long-Term Orientation (beta) & 0.111 & 0.094 & 0.072 & 0.081 & 0.043 & -0.052 & -0.060 & -0.017 \\
\hline N_clust & 93 & 85 & 93 & 85 & 83 & 96 & 92 & 95 \\
\hline $\begin{array}{l}\text { Notes. The table reports OLS estimates, with sta } \\
\text { during the academic years 2002-2012. The samp } \\
\text { when available (Canada, Mexico, and Puerto Ris } \\
\text { details in the text and the appendix for how the } \\
\text { Assessment Test math score in grade } 3 \text { (standarc } \\
0 \text { and variance } 1 \text { ), change in reading score fron } \\
\text { entering the } 9^{\text {th }} \text { grade for the first time), absenc } \\
\text { the student was involved in a disciplinary incid } \\
\text { grade at least once). Individual controls are the } \\
\text { Orientation" variable is based on Hofstede ( } 2010 \\
\text { the } 1 \%, 5 \% \text {, and } 10 \% \text { levels. }\end{array}$ & $\begin{array}{l}\text { includes secor } \\
\text { or the langua } \\
\text { ching betwee } \\
\text { d with mean } 0 \\
\text { ade } 3 \text { to grad } \\
\text { ates (the perce } \\
\text { defined as s } \\
\text { me as in Tabl } \\
\text { nd is measure }\end{array}$ & $\begin{array}{l}\text { ed at the lang } \\
\text { generation imt } \\
\text { spoken at ho } \\
\text { anguage and c } \\
\text { d variance 1), } \\
\text {, high school } \\
\text { age of days in } \\
\text { ous offences } \\
\text { C. Columns } 2 \\
\text { n a } 0-1 \text { scale. }\end{array}$ & $\begin{array}{l}\text { iigrants (extende } \\
\text { me for the remai } \\
\text { untries has been } \\
\text { the change in ma } \\
\text { graduation (a du } \\
\text { which the studer } \\
\text { ften leading to } \\
\text { and } 4 \text { also contro } \\
\text { We describe in do }\end{array}$ & $\begin{array}{l}\text { definition) de } \\
\text { ing students } \mathrm{f} \\
\text { mplemented. } \\
\text { score from gy } \\
\text { my for wheth } \\
\text { is absent duri } \\
\text { sspension), anc } \\
\text { for the math } \\
\text { ails all the var }\end{array}$ & $\begin{array}{l}\text { using the } \\
\text { hich the cr } \\
\text { dependent } \\
3 \text { to grade } \\
\text { he student } \\
\text { he academi } \\
\text { ention (an } \\
\text { e and readi } \\
s \text { in the on }\end{array}$ & $\begin{array}{l}\text { ormation on th } \\
\text { try of origin of } \\
\text { iables measure } \\
\text { reading score ir } \\
\text { eived a standar } \\
\text { ear), disciplinar } \\
\text { icator for whet } \\
\text { score in grade } \\
\text { Appendix. *** }\end{array}$ & $\begin{array}{l}\text { n } 1992 \text { and } 2 \\
\text { ountry of ori } \\
\text { e mother is } \\
\text { dents' Florid } \\
\text { ade } 3 \text { (standa } \\
\text { iploma withir } \\
\text { cidents (a du } \\
\text { the student } \\
\text { espectively. } \\
\text {, and * indic }\end{array}$ & $\begin{array}{l}\text { and observed } \\
\text { of the mother } \\
\text { available. See } \\
\text { omprehensive } \\
\text { ed with mean } \\
\text { ur years after } \\
\text { y for whether } \\
\text { eats the same } \\
\text { "Long Term } \\
\text { significance at }\end{array}$ \\
\hline
\end{tabular}


Table 6

Long-Term Orientation and educational performance, controlling for maternal
characteristics, FLDOE

Second generation immigrants, extended definition

\begin{tabular}{|c|c|c|c|c|c|c|}
\hline \multirow[b]{2}{*}{ VARIABLES } & (1) & (2) & (3) & (4) & (5) & (6) \\
\hline & \multicolumn{6}{|c|}{ Math score, 3rd grade } \\
\hline Long-Term Orientation & $\begin{array}{c}0.734 * * * \\
(0.128)\end{array}$ & $\begin{array}{c}0.757 * * * \\
(0.125)\end{array}$ & $\begin{array}{c}0.720 * * * \\
(0.123)\end{array}$ & $\begin{array}{c}0.757 * * * \\
(0.123)\end{array}$ & $\begin{array}{c}0.750 * * * \\
(0.122)\end{array}$ & $\begin{array}{c}0.697 * * * \\
(0.124)\end{array}$ \\
\hline Mother high school graduate & $\begin{array}{c}0.107 * * * \\
(0.021)\end{array}$ & & & & & $\begin{array}{c}0.083 * * * \\
(0.020)\end{array}$ \\
\hline Mother attended some college & $\begin{array}{c}0.206^{* * *} \\
(0.022)\end{array}$ & & & & & $\begin{array}{c}0.170^{* * *} \\
(0.020)\end{array}$ \\
\hline Mother 4yr college graduate & $\begin{array}{c}0.385^{* * *} \\
(0.017)\end{array}$ & & & & & $\begin{array}{c}0.337 * * * \\
(0.015)\end{array}$ \\
\hline Mother teen pregnancy & & $\begin{array}{c}-0.132^{* * *} \\
(0.019)\end{array}$ & & & & $\begin{array}{c}-0.070 * * * \\
(0.024)\end{array}$ \\
\hline Mother married at time of birth & & & $\begin{array}{c}0.128^{* * *} \\
(0.011)\end{array}$ & & & $\begin{array}{c}0.102^{* * *} \\
(0.007)\end{array}$ \\
\hline Number of older siblings & & & & $\begin{array}{c}-0.027 * * * \\
(0.003)\end{array}$ & & $\begin{array}{c}-0.028 * * * \\
(0.004)\end{array}$ \\
\hline Median income in zipcode of birth $(100,000$ of $\$)$ & & & & & $\begin{array}{c}0.297 * * * \\
(0.028)\end{array}$ & $\begin{array}{c}0.173^{* * *} \\
(0.026)\end{array}$ \\
\hline Observations & 206,143 & 207,509 & 207,531 & 204,971 & 185,595 & 184,331 \\
\hline R-squared & 0.361 & 0.352 & 0.355 & 0.353 & 0.357 & 0.368 \\
\hline Year*school FE & YES & YES & YES & YES & YES & YES \\
\hline Individual controls & YES & YES & YES & YES & YES & YES \\
\hline Dependent Variable (mean) & 0.000 & 0.000 & 0.000 & 0.000 & 0.000 & 0.000 \\
\hline Dependent Variable (sd) & 1.000 & 1.000 & 1.000 & 1.000 & 1.000 & 1.000 \\
\hline Long-Term Orientation (mean) & 0.207 & 0.207 & 0.207 & 0.207 & 0.207 & 0.207 \\
\hline Long-Term Orientation (sd) & 0.141 & 0.141 & 0.141 & 0.141 & 0.143 & 0.143 \\
\hline Long-Term Orientation (beta) & 0.104 & 0.107 & 0.102 & 0.107 & 0.107 & 0.100 \\
\hline N_clust & 91 & 91 & 91 & 91 & 90 & 90 \\
\hline
\end{tabular}

Notes. The table reports OLS estimates, with standard errors clustered at the language/country level. The unit of observation is a student born between 1992 and 2002 and observed during the academic years 2002-2012. The sample includes second generation immigrants (extended definition) defined using the information on the country of origin of the mother when available (Canada, Mexico, and Puerto Rico), or the language spoken at home for the remaining students for which the country of origin of the mother is not available. See details in the text and the appendix for how the matching between language and countries has been implemented. The dependent variable measures students' Florida Comprehensive Assessment Test math score in grade 3 (standardized with mean 0 and variance 1). All the regressions include the same individual controls described in Table 2 (coefficients not reported). Maternal controls include education dummies (high school, some college and college graduate; the excluded group is college drop-out), whether the mother was younger than 16 when she gave birth, the mother's marital status at time of birth, the number of older siblings, and the median income in the zip code of the place of residence at time of birth (measured in 1999). The "Long Term Orientation" variable is based on Hofstede (2010) and is measured on a 0-1 scale. We describe in details all the variables in the online Appendix. $* * *, * *$, and $*$ indicate significance at the $1 \%, 5 \%$, and $10 \%$ levels. 


\section{Table 7}

Long-Term Orientation and performance in mathematics, controlling for other country of origin characteristics, FLDOE First generation immigrants

\begin{tabular}{|c|c|c|c|c|c|c|c|c|c|c|c|c|}
\hline \multirow[b]{2}{*}{ VARIABLES } & (1) & (2) & (3) & (4) & (5) & (6) & (7) & (8) & (9) & $(10)$ & (11) & $(12)$ \\
\hline & \multicolumn{7}{|c|}{ Math score, 3rd grade } & \multicolumn{5}{|c|}{ Math score, change 3 rd to 8 th } \\
\hline \multirow[t]{2}{*}{ Long-Term Orientation } & $0.562 * * *$ & $0.414 * * *$ & $0.588^{* * *}$ & $0.553 * * *$ & $0.601 * * *$ & * $0.440 * * *$ & $0.413 * * * 0$ & $0.355^{* * *}$ & $0.430^{* * *}$ & $0.431^{* * *}$ & $0.466 * * *$ & *0.292*** \\
\hline & $(0.073)$ & $(0.131)$ & $(0.129)$ & $(0.092)$ & $(0.145)$ & $(0.129)$ & $(0.075)$ & $(0.102)$ & $(0.114)$ & $(0.094)$ & $(0.149)$ & $(0.093)$ \\
\hline \multirow[t]{2}{*}{ Log GDP pc year 2000 ppp } & $-0.139 * * *$ & & & & & $-0.147^{* * *}$ & $-0.102^{* * *}$ & & & & & $-0.218^{* * *}$ \\
\hline & $(0.018)$ & & & & & $(0.038)$ & $(0.018)$ & & & & & $(0.034)$ \\
\hline \multirow[t]{2}{*}{ Distance from the US (log) } & & $0.121^{* *}$ & & & & -0.009 & & $0.051^{* *}$ & & & & -0.004 \\
\hline & & $(0.046)$ & & & & $(0.027)$ & & $(0.023)$ & & & & $(0.025)$ \\
\hline \multirow[t]{2}{*}{ Savings over GDP/100 } & & & -0.182 & & & -0.240 & & & 0.181 & & & 0.064 \\
\hline & & & $(0.320)$ & & & $(0.155)$ & & & $(0.173)$ & & & $(0.117)$ \\
\hline \multirow[t]{2}{*}{ Education selection to Florida } & & & & $0.410^{* * *}$ & & $0.286^{* * *}$ & & & & $0.213 * * *$ & & 0.051 \\
\hline & & & & $(0.071)$ & & $(0.057)$ & & & & $(0.049)$ & & $(0.055)$ \\
\hline \multirow[t]{2}{*}{ Mean PISA score in Math } & & & & & $-0.113^{* *}$ & 0.101 & & & & & -0.053 & $0.167^{* * *}$ \\
\hline & & & & & $(0.043)$ & $(0.063)$ & & & & & $(0.056)$ & $(0.047)$ \\
\hline Observations & 69,649 & 69,652 & 69,637 & 69,031 & 54,535 & 54,461 & 28,046 & 28,046 & 28,039 & 27,736 & 22,799 & 22,775 \\
\hline R-squared & 0.464 & 0.461 & 0.458 & 0.464 & 0.464 & 0.469 & 0.421 & 0.417 & 0.417 & 0.422 & 0.434 & 0.442 \\
\hline Year*school FE & YES & YES & YES & YES & YES & YES & YES & YES & YES & YES & YES & YES \\
\hline Individual controls & YES & YES & YES & YES & YES & YES & YES & YES & YES & YES & YES & YES \\
\hline Dependent Variable (mean) & 0.000 & 0.000 & 0.000 & 0.000 & 0.000 & 0.000 & 0.000 & 0.000 & 0.000 & 0.000 & 0.000 & 0.000 \\
\hline Dependent Variable (sd) & 1.000 & 1.000 & 1.000 & 1.000 & 1.000 & 1.000 & 0.783 & 0.783 & 0.783 & 0.783 & 0.791 & 0.791 \\
\hline Long-Term Orientation (mean) & 0.255 & 0.255 & 0.255 & 0.252 & 0.287 & 0.286 & 0.254 & 0.254 & 0.254 & 0.251 & 0.276 & 0.275 \\
\hline Long-Term Orientation (sd) & 0.192 & 0.192 & 0.192 & 0.189 & 0.177 & 0.176 & 0.190 & 0.190 & 0.190 & 0.186 & 0.174 & 0.174 \\
\hline Long-Term Orientation (beta) & 0.108 & 0.079 & 0.113 & 0.105 & 0.106 & 0.077 & 0.100 & 0.086 & 0.104 & 0.102 & 0.103 & 0.064 \\
\hline N_clust & 88 & 89 & 88 & 76 & 61 & 53 & 84 & 84 & 83 & 73 & 57 & 52 \\
\hline
\end{tabular}

Notes. The table reports OLS estimates, with standard errors clustered at the country level. The unit of observation is a student born between 1992 and 2002 and observed during the academic years 2002-2012. The sample includes first generation immigrants defined using both the information on the country of origin and the language spoken at home. The dependent variable measures students' Florida Comprehensive Assessment Test math score in grade 3 (standardized with mean 0 and variance 1). All the regressions include the same individual controls described in Table 2 (coefficients not reported). The "Long Term Orientation" variable is based on Hofstede (2010) and is measured on a 0-1 scale. The additional country-controls and all the remaining variables are described in the online Appendix. ***, **, and * indicate significance at the $1 \%, 5 \%$, and $10 \%$ levels. 
Table 8

Long-Term Orientation and performance in mathematics, controlling for other country of origin characteristics, FLDOE

Second generation immigrants, extended definition

\begin{tabular}{|c|c|c|c|c|c|c|c|c|c|c|c|c|}
\hline \multirow[b]{2}{*}{ VARIABLES } & (1) & (2) & (3) & (4) & (5) & (6) & (7) & (8) & (9) & $(10)$ & (11) & (12) \\
\hline & \multicolumn{6}{|c|}{ Math score, 3 rd grade } & \multicolumn{6}{|c|}{ Math score, change 3 rd to 8 th } \\
\hline \multirow[t]{2}{*}{ Long-Term Orientation } & $0.728 * * *$ & $0.612 * * *$ & $0.723 * * *$ & $0.918^{* * *}$ & $0.529 * * *$ & $0.383 * *$ & $0.447 * * *$ & $0.393 * * *$ & $0.473 * * *$ & $0.590 * * *$ & $0.458 * * *$ & $0.376^{* *}$ \\
\hline & $(0.115)$ & $(0.174)$ & $(0.095)$ & $(0.110)$ & $(0.145)$ & $(0.176)$ & $(0.085)$ & $(0.105)$ & $(0.090)$ & $(0.082)$ & $(0.099)$ & $(0.147)$ \\
\hline \multirow[t]{2}{*}{ Log GDP pc year 2000 ppp } & $-0.079 *$ & & & & & $-0.085^{* * *}$ & $-0.080 * * *$ & & & & & $-0.131^{* * *}$ \\
\hline & $(0.041)$ & & & & & $(0.030)$ & $(0.026)$ & & & & & $(0.018)$ \\
\hline \multirow[t]{2}{*}{ Distance from the US (log) } & & 0.097 & & & & -0.054 & & $0.063^{* * *}$ & & & & -0.025 \\
\hline & & $(0.076)$ & & & & $(0.033)$ & & $(0.024)$ & & & & $(0.016)$ \\
\hline \multirow[t]{2}{*}{ Savings over GDP/100 } & & & $0.714 * *$ & & & $0.881 * *$ & & & 0.244 & & & 0.407 \\
\hline & & & $(0.324)$ & & & $(0.423)$ & & & $(0.211)$ & & & $(0.313)$ \\
\hline \multirow[t]{2}{*}{ Education selection to Florida } & & & & 0.045 & & $0.285^{* * *}$ & & & & 0.084 & & -0.029 \\
\hline & & & & $(0.123)$ & & $(0.057)$ & & & & $(0.055)$ & & $(0.082)$ \\
\hline \multirow[t]{2}{*}{ Mean PISA score in Math } & & & & & 0.072 & 0.076 & & & & & 0.004 & 0.024 \\
\hline & & & & & $(0.051)$ & $(0.060)$ & & & & & $(0.037)$ & $(0.040)$ \\
\hline Observations & 304,449 & 305,382 & 304,522 & 295,119 & 54,797 & 53,916 & 106,832 & 107,053 & 106,696 & 103,388 & 17,760 & 17,438 \\
\hline R-squared & 0.344 & 0.343 & 0.342 & 0.343 & 0.484 & 0.488 & 0.312 & 0.311 & 0.310 & 0.314 & 0.479 & 0.485 \\
\hline Year*school FE & YES & YES & YES & YES & YES & YES & YES & YES & YES & YES & YES & YES \\
\hline Individual controls & YES & YES & YES & YES & YES & YES & YES & YES & YES & YES & YES & YES \\
\hline Dependent Variable (mean) & 0.000 & 0.000 & 0.000 & 0.000 & 0.000 & 0.000 & 0.000 & 0.000 & 0.000 & 0.000 & 0.000 & 0.000 \\
\hline Dependent Variable (sd) & 1.000 & 1.000 & 1.000 & 1.000 & 1.000 & 1.000 & 0.775 & 0.775 & 0.776 & 0.777 & 0.745 & 0.746 \\
\hline Long-Term Orientation (mean) & 0.208 & 0.209 & 0.208 & 0.199 & 0.339 & 0.331 & 0.210 & 0.211 & 0.210 & 0.201 & 0.353 & 0.344 \\
\hline Long-Term Orientation (sd) & 0.142 & 0.144 & 0.143 & 0.128 & 0.157 & 0.147 & 0.146 & 0.147 & 0.146 & 0.133 & 0.164 & 0.154 \\
\hline Long-Term Orientation (beta) & 0.103 & 0.088 & 0.103 & 0.118 & 0.083 & 0.056 & 0.084 & 0.074 & 0.089 & 0.101 & 0.101 & 0.078 \\
\hline N_clust & 91 & 93 & 91 & 71 & 48 & 42 & 83 & 85 & 83 & 66 & 46 & 41 \\
\hline $\begin{array}{l}\text { Notes. The table reports OI } \\
\text { student born between } 1992 \\
\text { immigrants (extended definitic } \\
\text { and Puerto Rico), or the lan } \\
\text { available. See details in the te } \\
\text { dependent variable measures } \\
\text { variance 1). All the regressio } \\
\text { country-controls are describe } \\
\text { measured on a } 0-1 \text { scale. We }\end{array}$ & $\begin{array}{l}\text { ion) define } \\
\text { guage spo } \\
\text { ext and th } \\
\text { students' } \\
\text { ons includ } \\
\text { ed in the }\end{array}$ & $\begin{array}{l}\text { oken at } h \\
\text { he appenc } \\
\text { ' Florida } \\
\text { de the sar }\end{array}$ & $\begin{array}{l}\text { the inforr } \\
\text { dome for } \\
\text { dix for ho } \\
\text { Compreh } \\
\text { me indivi }\end{array}$ & $\begin{array}{l}\text { mation } \\
\text { the re } \\
\text { ow the } \\
\text { ensive } \\
\text { idual c }\end{array}$ & $\begin{array}{l}\text { aining } \\
\text { natchin } \\
\text { Assessr } \\
\text { trols }\end{array}$ & $\begin{array}{l}\text { untry of } \\
\text { udents for } \\
\text { between } \\
\text { nt Test } n \\
\text { scribed in }\end{array}$ & $\begin{array}{l}\text { rigin } \\
\text { whic } \\
\text { angua } \\
\text { ath sc } \\
\text { Tabl }\end{array}$ & $\begin{array}{l}\text { country } \\
\text { 2. The } \\
\text { the mo } \\
\text { the co } \\
\text { and cc } \\
\text { e in gr } \\
\text { (coeff }\end{array}$ & $\begin{array}{l}\text { er whe } \\
\text { try of } \\
\text { ntries } \\
\text { le } 3 \text { (st } \\
\text { ients }\end{array}$ & $\begin{array}{l}\text { unit } \\
\text { ludes } \\
\text { vailabl } \\
\text { gin of } \\
\text { been } \\
\text { ardize }\end{array}$ & $\begin{array}{l}\text { Cana } \\
\text { e m } \\
\text { plem } \\
\text { vith } \\
\text { Th }\end{array}$ & $\begin{array}{l}\text { on is a } \\
\text { neration } \\
\text { Mexico, } \\
\text { is not } \\
\text { d. The } \\
\text { n } 0 \text { and } \\
\text { ditional }\end{array}$ \\
\hline
\end{tabular}


Table 9

Long-Term Orientation and educational performance, robustness to sample selection, FLDOE

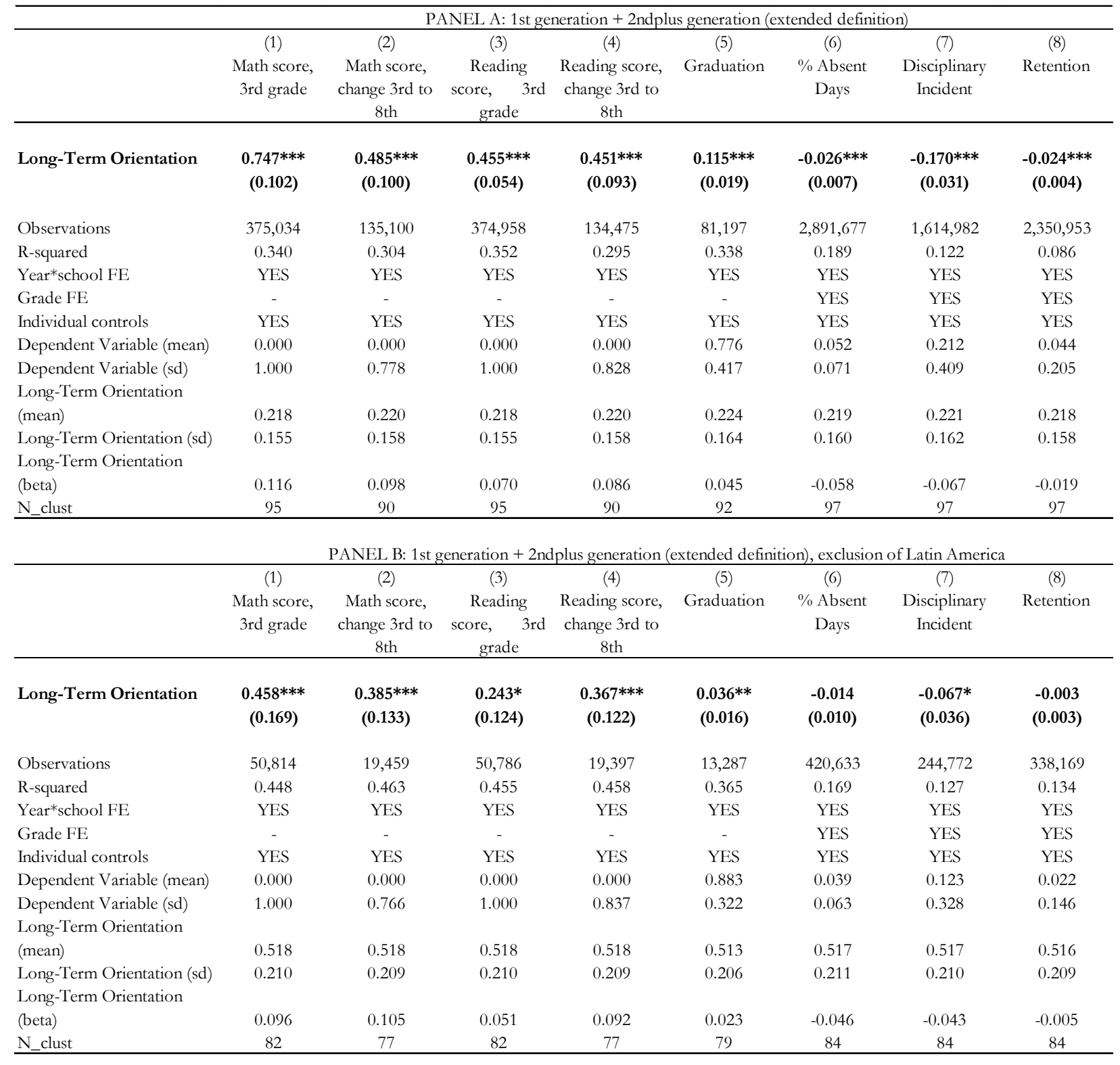


Table 9

\section{Long-Term Orientation and educational performance, robustness to sample selection (continued), FLDOE}

PANEL C: 1st generation + 2ndplus generation (extended definition), exclusion of Asia

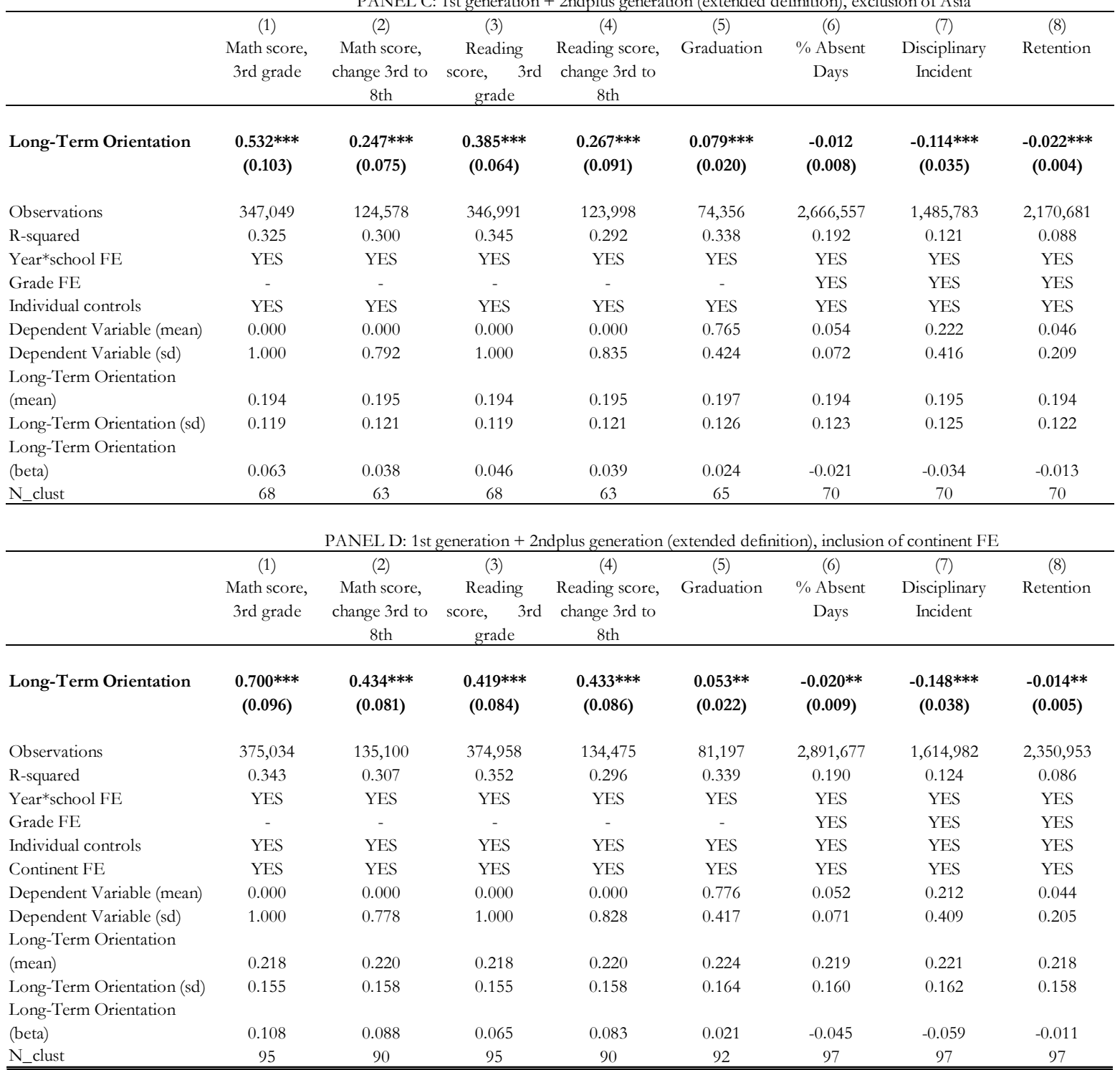

Notes. The table reports OLS estimates, with standard errors clustered at the language/country level. The unit of observation is a student born between 1992 and 2002 and observed during the academic years 2002-2012. The sample pools together first generation immigrants defined using the information on both the country of origin and the language spoken at home, and second generation immigrants (extended definition) defined using the information on the country of origin of the mother when available (Canada, Mexico, and Puerto Rico), or the language spoken at home for the remaining students for which the country of origin of the mother is not available. See details in the text and the appendix for how the matching between language and countries has been implemented. Panel A and Panel D include the overall sample. Panel B excludes immigrants from Central and Latin America. Panel C excludes immigrants from Asia. The dependent variables are: students' Florida Comprehensive Assessment Test math score in grade 3 (standardized with mean 0 and variance 1 ), the change in math score from grade 3 to grade 8 , reading score in grade 3 (standardized with mean 0 and variance 1), change in reading score from grade 3 to grade 8 , high school graduation (a dummy for whether the student received a standard diploma within four years after entering the $9^{\text {th }}$ grade for the first time), absence rates (the percentage of days in which the student is absent during the academic year), disciplinary incidents (a dummy for whether the student was involved in a disciplinary incident, defined as serious offences often leading to suspension), and retention (an indicator for whether the student repeats the same grade at least once). All regressions include the same individual controls described in Table 2 (coefficients not reported). Panel D also includes continent fixed effects. Columns 2 and 4 also control for the math score and reading score in grade 3, respectively. The "Long Term Orientation" variable is based on Hofstede (2010) and is measured on a $0-1$ scale. We describe in details all the variables in the online Appendix. $* * *, * *$, and $*$ indicate significance at the $1 \%, 5 \%$, and $10 \%$ levels. 
Table 10

Long-Term Orientation and educational performance, heterogeneity in family characteristics, FLDOE

Second Generation immigrants, extended definition

\begin{tabular}{|c|c|c|c|c|c|c|c|}
\hline & $(1)$ & $(2)$ & (3) & (4) & (5) & $(6)$ & $(7)$ \\
\hline VARIABLES & \multicolumn{7}{|c|}{ Math score, 3rd grade } \\
\hline Long-Term Orientation (LTO) & $\begin{array}{c}0.891 * * * \\
(0.147)\end{array}$ & $\begin{array}{c}0.699 * * * \\
(0.124)\end{array}$ & $\begin{array}{c}0.637 * * * \\
(0.171)\end{array}$ & $\begin{array}{c}0.696 * * * \\
(0.124)\end{array}$ & $\begin{array}{c}0.752 * * * \\
(0.211)\end{array}$ & $\begin{array}{c}0.666 * * * \\
(0.106)\end{array}$ & $\begin{array}{c}0.818^{* * *} \\
(0.202)\end{array}$ \\
\hline Mother high school graduate*LTO & $\begin{array}{c}-0.173^{*} \\
(0.093)\end{array}$ & & & & & & $\begin{array}{c}-0.209 * * \\
(0.087)\end{array}$ \\
\hline Mother attended some college*LTO & $\begin{array}{c}-0.319 \text { *** } \\
(0.106)\end{array}$ & & & & & & $\begin{array}{c}-0.358^{* * *} \\
(0.093)\end{array}$ \\
\hline Mother 4yr college graduate*LTO & $\begin{array}{c}-0.224^{* *} \\
(0.108)\end{array}$ & & & & & & $\begin{array}{c}-0.268^{* * *} \\
(0.099)\end{array}$ \\
\hline Mother teen pregnancy*LTO & & $\begin{array}{l}-0.534 \\
(0.329)\end{array}$ & & & & & $\begin{array}{c}-0.679 * * \\
(0.341)\end{array}$ \\
\hline Mother married at time of birth*LTO & & & $\begin{array}{c}0.074 \\
(0.110)\end{array}$ & & & & $\begin{array}{l}0.145^{*} \\
(0.081)\end{array}$ \\
\hline Number of older siblings*LTO & & & & $\begin{array}{c}0.001 \\
(0.025)\end{array}$ & & & $\begin{array}{l}-0.020 \\
(0.023)\end{array}$ \\
\hline Median income in zipcode of birth $(100,000$ of $\$) *$ LTO & & & & & $\begin{array}{l}-0.113 \\
(0.277)\end{array}$ & & $\begin{array}{l}-0.022 \\
(0.204)\end{array}$ \\
\hline Free or Reduced Priced Lunch*LTO & & & & & & $\begin{array}{c}0.068 \\
(0.092)\end{array}$ & $\begin{array}{c}0.039 \\
(0.073)\end{array}$ \\
\hline Mother high school graduate & $\begin{array}{c}0.116^{* * *} \\
(0.028)\end{array}$ & $\begin{array}{c}0.083^{* * *} \\
(0.020)\end{array}$ & $\begin{array}{c}0.083^{* * *} \\
(0.020)\end{array}$ & $\begin{array}{c}0.083^{* * *} \\
(0.020)\end{array}$ & $\begin{array}{c}0.083^{* * *} \\
(0.020)\end{array}$ & $\begin{array}{c}0.083^{* * *} \\
(0.020)\end{array}$ & $\begin{array}{c}0.122^{* * *} \\
(0.027)\end{array}$ \\
\hline Mother attended some college & $\begin{array}{c}0.232^{* * *} \\
(0.023)\end{array}$ & $\begin{array}{c}0.170^{* * *} \\
(0.019)\end{array}$ & $\begin{array}{c}0.170^{* * *} \\
(0.020)\end{array}$ & $\begin{array}{c}0.170^{* * *} \\
(0.020)\end{array}$ & $\begin{array}{c}0.170^{* * *} \\
(0.020)\end{array}$ & $\begin{array}{c}0.170^{* * *} \\
(0.019)\end{array}$ & $\begin{array}{c}0.240 * * * \\
(0.020)\end{array}$ \\
\hline Mother 4yr college graduate & $\begin{array}{c}0.381 \text { *** } \\
(0.021)\end{array}$ & $\begin{array}{c}0.337^{* * *} \\
(0.015)\end{array}$ & $\begin{array}{c}0.337^{* * *} \\
(0.015)\end{array}$ & $\begin{array}{c}0.337^{* * *} \\
(0.015)\end{array}$ & $\begin{array}{c}0.337^{* * *} \\
(0.015)\end{array}$ & $\begin{array}{c}0.338^{* * *} \\
(0.015)\end{array}$ & $\begin{array}{c}0.390 * * * \\
(0.017)\end{array}$ \\
\hline Mother teen pregnancy & $\begin{array}{c}-0.065^{* * *} \\
(0.023)\end{array}$ & $\begin{array}{c}0.020 \\
(0.058)\end{array}$ & $\begin{array}{c}-0.071 \text { *** } \\
(0.024)\end{array}$ & $\begin{array}{c}-0.070 * * * \\
(0.024)\end{array}$ & $\begin{array}{c}-0.070 * * * \\
(0.024)\end{array}$ & $\begin{array}{c}-0.069 * * * \\
(0.024)\end{array}$ & $\begin{array}{c}0.048 \\
(0.057)\end{array}$ \\
\hline Mother married at time of birth & $\begin{array}{c}0.101 \text { *** } \\
(0.007)\end{array}$ & $\begin{array}{c}0.102^{* * *} \\
(0.007)\end{array}$ & $\begin{array}{c}0.088^{* * *} \\
(0.019)\end{array}$ & $\begin{array}{c}0.102^{* * *} \\
(0.007)\end{array}$ & $\begin{array}{c}0.102^{* * *} \\
(0.007)\end{array}$ & $\begin{array}{c}0.102^{* * *} \\
(0.007)\end{array}$ & $\begin{array}{c}0.074 * * * \\
(0.014)\end{array}$ \\
\hline Number of older siblings & $\begin{array}{c}-0.027 * * * \\
(0.004)\end{array}$ & $\begin{array}{c}-0.028^{* * *} \\
(0.004)\end{array}$ & $\begin{array}{c}-0.028^{* * *} * \\
(0.004)\end{array}$ & $\begin{array}{c}-0.028^{* * *} \\
(0.008)\end{array}$ & $\begin{array}{c}-0.028^{* * *} \\
(0.004)\end{array}$ & $\begin{array}{c}-0.028 * * * \\
(0.004)\end{array}$ & $\begin{array}{c}-0.024 * * * \\
(0.007)\end{array}$ \\
\hline Median income in zipcode of birth $(100,000$ of $\$)$ & $\begin{array}{c}0.172^{* * *} \\
(0.026)\end{array}$ & $\begin{array}{c}0.173^{* * *} \\
(0.026)\end{array}$ & $\begin{array}{c}0.172^{* * *} \\
(0.026)\end{array}$ & $\begin{array}{c}0.173^{* * *} \\
(0.026)\end{array}$ & $\begin{array}{c}0.198^{* * *} \\
(0.062)\end{array}$ & $\begin{array}{c}0.173^{* * *} \\
(0.026)\end{array}$ & $\begin{array}{c}0.177 \text { *** } \\
(0.048)\end{array}$ \\
\hline Free or Reduced Priced Lunch & $\begin{array}{c}-0.155^{* * *} \\
(0.009)\end{array}$ & $\begin{array}{c}-0.154 * * * \\
(0.008)\end{array}$ & $\begin{array}{c}-0.154 * * * \\
(0.008)\end{array}$ & $\begin{array}{c}-0.154^{* * *} \\
(0.008)\end{array}$ & $\begin{array}{c}-0.154 * * * \\
(0.008)\end{array}$ & $\begin{array}{c}-0.169 * * * \\
(0.017)\end{array}$ & $\begin{array}{c}-0.163^{* * *} \\
(0.014)\end{array}$ \\
\hline Observations & 184,331 & 184,331 & 184,331 & 184,331 & 184,331 & 184,331 & 184,331 \\
\hline R-squared & 0.368 & 0.368 & 0.368 & 0.368 & 0.368 & 0.368 & 0.369 \\
\hline Year*school FE & YES & YES & YES & YES & YES & YES & YES \\
\hline Individual controls & YES & YES & YES & YES & YES & YES & YES \\
\hline Dependent Variable (mean) & 0.000 & 0.000 & 0.000 & 0.000 & 0.000 & 0.000 & 0.000 \\
\hline Dependent Variable (sd) & 1.000 & 1.000 & 1.000 & 1.000 & 1.000 & 1.000 & 1.000 \\
\hline Long-Term Orientation (mean) & 0.207 & 0.207 & 0.207 & 0.207 & 0.207 & 0.207 & 0.207 \\
\hline Long-Term Orientation (sd) & 0.143 & 0.143 & 0.143 & 0.143 & 0.143 & 0.143 & 0.143 \\
\hline Long-Term Orientation (beta) & 0.127 & 0.100 & 0.091 & 0.100 & 0.108 & 0.095 & 0.117 \\
\hline N_clust & 90 & 90 & 90 & 90 & 90 & 90 & 90 \\
\hline
\end{tabular}

Notes. The table reports OLS estimates, with standard errors clustered at the language/country level. The unit of observation is a student born between 1992 and 2002 and observed during the academic years 2002-2012. The sample includes second generation immigrants (extended definition) defined using the information on the country of origin of the mother when available (Canada, Mexico, and Puerto Rico), or the language spoken at home for the remaining students for which the country of origin of the mother is not available. See details in the text and the appendix for how the matching between language and countries has been implemented. See details in the text and the appendix for how the matching between languages and countries has been implemented. The dependent variable measure students' Florida Comprehensive Assessment Test math score in grade 3 (standardized with mean 0 and variance 1). All the regressions include the same individual controls described in Table 2 (coefficients not reported). Maternal controls are the same as in Table 6. The "Long Term Orientation" variable is based on Hofstede (2010) and is measured on a 0-1 scale. We describe in details all the variables in the online Appendix. ***, **, and * indicate significance at the $1 \%, 5 \%$, and $10 \%$ levels. 
Table 11

Long-Term Orientation and school composition,

First and second generation (extended definition) immigrants

\begin{tabular}{|c|c|c|c|c|c|c|c|c|c|c|}
\hline VARIABLES & $\begin{array}{c}1) \\
\text { Math score, } \\
\text { 3rd grade }\end{array}$ & $\begin{array}{l}\text { Matl } \\
\text { change }\end{array}$ & $\begin{array}{l}\text { (3) } \\
\text { ore, } \\
\text { to } 8 \text { th } \\
\end{array}$ & $\begin{array}{c}\text { (4) } \\
\text { Reading score, } \\
\text { 3rd grade }\end{array}$ & $\begin{array}{l}\text { (5) } \\
\text { Readi } \\
\text { change }\end{array}$ & $\begin{array}{l}\text { (6) } \\
\text { score, } \\
\text { to } 8 \text { th }\end{array}$ & $\begin{array}{c}\text { (7) } \\
\text { Graduation }\end{array}$ & $\begin{array}{c}(8) \\
\% \text { Absent } \\
\text { Days }\end{array}$ & $\begin{array}{c}(9) \\
\text { Disciplinary } \\
\text { Incident }\end{array}$ & $\begin{array}{c}(10) \\
\text { Retention }\end{array}$ \\
\hline Long-Term Orientation (LTO) & $\begin{array}{c}0.662 * * * \\
(0.197)\end{array}$ & $\begin{array}{c}0.478^{* * *} \\
(0.132)\end{array}$ & $\begin{array}{c}0.522 * * * \\
(0.161)\end{array}$ & $\begin{array}{c}0.378^{* *} \\
(0.147)\end{array}$ & $\begin{array}{c}0.490 * * * \\
(0.128)\end{array}$ & $\begin{array}{c}0.509 * * * \\
(0.161)\end{array}$ & $\begin{array}{c}0.069 * * * \\
(0.022)\end{array}$ & $\begin{array}{c}-0.025^{* *} \\
(0.012)\end{array}$ & $\begin{array}{c}-0.108 * * \\
(0.047)\end{array}$ & $\begin{array}{l}-0.006 * \\
(0.003)\end{array}$ \\
\hline Fraction speaking the same language $(\log ) *$ LTO & $\begin{array}{c}0.169 * * * \\
(0.057)\end{array}$ & & $\begin{array}{l}0.159 * * \\
(0.064)\end{array}$ & $\begin{array}{c}0.070 \\
(0.046)\end{array}$ & & $\begin{array}{l}0.133 \\
(0.081)\end{array}$ & $\begin{array}{c}0.023 \\
(0.014)\end{array}$ & $\begin{array}{c}-0.009 * * * \\
(0.003)\end{array}$ & $\begin{array}{c}-0.029^{* *} \\
(0.012)\end{array}$ & $\begin{array}{l}-0.002 \\
(0.001)\end{array}$ \\
\hline Fraction speaking the same language (log) & $\begin{array}{c}-0.101 * * * \\
(0.028)\end{array}$ & & $\begin{array}{c}-0.088^{* * *} \\
(0.031)\end{array}$ & $\begin{array}{c}-0.063^{* * *} \\
(0.019)\end{array}$ & & $\begin{array}{l}-0.071^{*} \\
(0.037)\end{array}$ & $\begin{array}{l}-0.013 \\
(0.008)\end{array}$ & $\begin{array}{c}0.005^{* * *} \\
(0.002)\end{array}$ & $\begin{array}{c}0.020^{* * *} \\
(0.006)\end{array}$ & $\begin{array}{l}0.002^{* *} \\
(0.001)\end{array}$ \\
\hline Fraction speaking the same language $(\log )$ in grade $3 *$ & & $\begin{array}{c}0.142 * * * \\
(0.048)\end{array}$ & & & $\begin{array}{c}0.147 * * \\
(0.061)\end{array}$ & & & & & \\
\hline Fraction speaking the same language $(\log )$ in grade 3 & & $\begin{array}{c}-0.079 * * * \\
(0.024)\end{array}$ & & & $\begin{array}{c}-0.093^{* * *} \\
(0.028)\end{array}$ & & & & & \\
\hline Observations & 47,992 & 17,945 & 17,945 & 47,963 & 17,876 & 17,876 & 11,369 & 384,139 & 219,673 & 307,507 \\
\hline R-squared & 0.453 & 0.458 & 0.458 & 0.460 & 0.451 & 0.451 & 0.377 & 0.180 & 0.129 & 0.136 \\
\hline Year*school FE & YES & YES & YES & YES & YES & YES & YES & YES & YES & YES \\
\hline Grade FE & - & - & - & - & - & - & - & YES & YES & YES \\
\hline Individual controls & YES & YES & YES & YES & YES & YES & YES & YES & YES & YES \\
\hline Dependent Variable (mean) & 0.000 & 0.000 & 0.000 & 0.000 & 0.000 & 0.000 & 0.878 & 0.040 & 0.126 & 0.023 \\
\hline Dependent Variable (sd) & 1.000 & 0.766 & 0.766 & 1.000 & 0.840 & 0.840 & 0.328 & 0.063 & 0.332 & 0.151 \\
\hline Long-Term Orientation (mean) & 0.528 & 0.531 & 0.531 & 0.528 & 0.532 & 0.532 & 0.535 & 0.531 & 0.532 & 0.530 \\
\hline Long-Term Orientation (sd) & 0.204 & 0.204 & 0.204 & 0.204 & 0.204 & 0.204 & 0.204 & 0.206 & 0.206 & 0.205 \\
\hline Long-Term Orientation (beta) & 0.135 & 0.128 & 0.139 & 0.077 & 0.119 & 0.124 & 0.043 & -0.082 & -0.067 & -0.008 \\
\hline N_clust & 91 & 83 & 83 & 91 & 83 & 83 & 83 & 95 & 93 & 94 \\
\hline
\end{tabular}

Notes. The table reports OLS estimates, with standard errors clustered at the language/country level. The unit of observation is a student born between 1992 and 2002 and observed during the academic years 2002-2012. The sample pools together first generation immigrants defined using the information on both the country of origin and the language spoken at home and second generation immigrants (extended definition) defined using the information on the country of origin of the mother when available (Canada, Mexico, and Puerto Rico), or the language spoken at home for the remaining students for which the country of origin of the mother is not available. See details in the text and the appendix for how the matching between language and countries has been implemented. The dependent variables measure students' Florida Comprehensive Assessment Test math score in grade 3 (standardized with mean 0 and variance 1), the change in math score from grade 3 to grade 8 , reading score in grade 3 (standardized with mean 0 and variance 1 ), change in reading score from grade 3 to grade 8 , high school graduation (a dummy for whether the student received a standard diploma within four years after entering the ${ }^{\text {th }}$ grade for the first time), absence rates (the percentage of days in which the student is absent during the academic year), disciplinary incidents (a dummy for whether the student was involved in a disciplinary incident, defined as serious offences often leading to suspension), and retention (an indicator for whether the student repeats the same grade at least once). Fraction of students speaking the same language is the ratio of students speaking a given language in a given year in a given school divided by the school population (including natives). Students speaking English, Spanish, or Haitian are not included in our regressions (but are still part of the denominator). All the regressions include the same individual controls described in Table 2 (coefficients not reported). Columns 2 and 4 also control for the math score and reading score in grade 3, respectively. The "Long Term Orientation" variable is based on Hofstede (2010) and is measured on a 0-1 scale. We describe in details all the variables on the online Appendix. ***, **, and * indicate significance at the $1 \%, 5 \%$, and $10 \%$ levels. 
Table 12

Enrollment in advanced classes, school choice and participation in gifted program

\begin{tabular}{|c|c|c|c|c|c|}
\hline VARIABLES & $\begin{array}{c}(1) \\
\text { Fraction of } \\
\text { advanced classes }\end{array}$ & $\begin{array}{c}(2) \\
\text { Fraction of } \\
\text { advanced classes } \\
\text { (scientific subjects) }\end{array}$ & $\begin{array}{c}\text { (3) } \\
\text { School Letter Score } \\
\text { (from A to F) at t-1, } \\
\text { (pre-) kindergarten }\end{array}$ & $\begin{array}{c}\text { (4) } \\
\text { School Letter Score } \\
\text { (from A to F) at t-1, } \\
\text { all grades }\end{array}$ & $\begin{array}{c}\text { (5) } \\
\text { Gifted in grade } 4\end{array}$ \\
\hline Long-Term Orientation & $\begin{array}{c}0.081 * * * \\
(0.018)\end{array}$ & $\begin{array}{c}0.032 * * * \\
(0.007)\end{array}$ & $\begin{array}{c}0.377 * * * \\
(0.126)\end{array}$ & $\begin{array}{c}0.328 * * * \\
(0.109)\end{array}$ & $\begin{array}{c}0.095 * * * \\
(0.017)\end{array}$ \\
\hline Male & $\begin{array}{c}-0.016^{* * *} \\
(0.001)\end{array}$ & $\begin{array}{c}-0.002^{* * *} \\
(0.000)\end{array}$ & $\begin{array}{l}-0.003 \\
(0.002)\end{array}$ & $\begin{array}{l}-0.001 \\
(0.002)\end{array}$ & $\begin{array}{c}0.002 \\
(0.004)\end{array}$ \\
\hline Age in months & $\begin{array}{c}0.000 \\
(0.000)\end{array}$ & $\begin{array}{c}0.000^{* * *} \\
(0.000)\end{array}$ & $\begin{array}{c}0.007 * * * \\
(0.001)\end{array}$ & $\begin{array}{c}-0.006^{* * *} \\
(0.001)\end{array}$ & $\begin{array}{c}-0.003 * * * \\
(0.001)\end{array}$ \\
\hline Free or Reduced Priced Lunch & $\begin{array}{c}-0.017^{* * *} \\
(0.002)\end{array}$ & $\begin{array}{c}-0.004^{* * *} \\
(0.001)\end{array}$ & $\begin{array}{c}-0.435^{* * *} \\
(0.041)\end{array}$ & $\begin{array}{c}-0.382^{* * *} \\
(0.037)\end{array}$ & $\begin{array}{c}0.025^{* * *} \\
(0.007)\end{array}$ \\
\hline Special education & $\begin{array}{c}0.010^{* * *} \\
(0.002)\end{array}$ & $\begin{array}{c}0.005^{* * *} \\
(0.001)\end{array}$ & $\begin{array}{c}0.060^{* * *} \\
(0.010)\end{array}$ & $\begin{array}{c}0.014 \\
(0.016)\end{array}$ & \\
\hline Enrolled in Limited English proficiency pro६ & $\begin{array}{c}0.012 * * * \\
(0.002)\end{array}$ & $\begin{array}{c}0.007 * * * \\
(0.001)\end{array}$ & $\begin{array}{c}-0.066^{* * *} \\
(0.013)\end{array}$ & $\begin{array}{c}-0.095^{* * *} \\
(0.018)\end{array}$ & $\begin{array}{c}0.005 \\
(0.011)\end{array}$ \\
\hline Math score, 8 th grade & $\begin{array}{c}0.046^{* * *} \\
(0.005)\end{array}$ & $\begin{array}{c}0.013^{* * *} \\
(0.002)\end{array}$ & & & \\
\hline Observations & 512,070 & 512,070 & 243,233 & $3,478,545$ & 26,308 \\
\hline R-squared & 0.336 & 0.215 & 0.208 & 0.246 & 0.419 \\
\hline Year*school FE & YES & YES & - & - & YES \\
\hline District FE & - & - & YES & YES & - \\
\hline Year FE & - & - & YES & YES & - \\
\hline Grade FE & YES & YES & - & YES & - \\
\hline Dependent Variable (mean) & 0.058 & 0.013 & 4.120 & 4.128 & 0.112 \\
\hline Dependent Variable (sd) & 0.145 & 0.054 & 0.991 & 1.012 & 0.316 \\
\hline Long-Term Orientation (mean) & 0.222 & 0.222 & 0.217 & 0.220 & 0.276 \\
\hline Long-Term Orientation (sd) & 0.162 & 0.162 & 0.152 & 0.160 & 0.205 \\
\hline Long-Term Orientation (beta) & 0.090 & 0.096 & 0.058 & 0.052 & 0.062 \\
\hline N_clust & 94 & 94 & 92 & 97 & 88 \\
\hline
\end{tabular}

Notes. The table reports OLS estimates, with standard errors clustered at the language/country level. The unit of observation is a student born between 1992 and 2002 and observed during the academic years 2002-2012. The sample pools together first generation immigrants defined using the information on both the country of origin and the language spoken at home and second generation immigrants (extended definition) defined using the information on the country of origin of the mother when available (Canada, Mexico, and Puerto Rico), or the language spoken at home for the remaining students for which the country of origin of the mother is not available. See details in the text and the appendix for how the matching between language and countries has been implemented. In columns (1) and (2) the sample is restricted to the students enrolled in grades $9^{\text {th }}$ to $12^{\text {th }}$ and the dependent variables are respectively the fraction of advanced classes (AP, IB, and/or AICE) taken by the student over the total number of classes taken by the student during a given academic year, the fraction of advanced classes in scientific or math subjects (AP, IB, and/or AICE) taken by the student over the total number of classes taken by the student during a given academic year. In column 3 the sample includes students enrolled the first time they enter the school system either in Kindergarten or pre-Kindergarten class and the dependent variables is the score earned by their school in year t-1. In column (4) the sample includes students in all grades and the dependent variable is the score earned by their school in year $\mathrm{t}-1$. These school scores are calculated by the Florida Department of Education to measure schools' quality. In column (5) the sample includes all students who were present in the data both in grade $3^{\text {rd }}$ and $4^{\text {th }}$, were not enrolled in a gifted program in 3rd grade, and were top performers in FCAT math and reading in third grade. The dependent variable is equal to one if the student is enrolled in a gifted program in grade 4 and equal to zero otherwise. All the regressions include the same individual controls described in Table 2. Columns 1 and 2 also control for the math score in grade 8. The "Long Term Orientation" variable is based on Hofstede (2010) and is measured on a 0-1 scale. We describe in details all the variables on the online Appendix. $* * *, * *$, and $*$ indicate significance at the $1 \%, 5 \%$, and $10 \%$ levels. 
Table 13

Educational performance and alternative measures of Long-Term Orientation, FLDOE

\begin{tabular}{|c|c|c|c|c|c|c|c|c|}
\hline & \multicolumn{8}{|c|}{ PANEL A: 1st generation + 2nd generation (extended definition) } \\
\hline & (1) & (2) & (3) & (4) & (5) & (6) & (7) & $(8)$ \\
\hline & $\begin{array}{l}\text { Math score, } \\
\text { 3rd grade }\end{array}$ & $\begin{array}{c}\text { Math score, } \\
\text { change } 3 \text { rd to } 8 \text { th }\end{array}$ & $\begin{array}{l}\text { Reading score, } \\
\text { 3rd grade }\end{array}$ & $\begin{array}{l}\text { Reading score, } \\
\text { change } 3 \text { rd to } 8 \text { th }\end{array}$ & Graduation & $\begin{array}{c}\% \text { Absent } \\
\text { Days }\end{array}$ & $\begin{array}{l}\text { Disciplinary } \\
\text { Incident }\end{array}$ & Retention \\
\hline Futureless Language (Chen) & $\begin{array}{c}0.473 * * * \\
(0.122)\end{array}$ & $\begin{array}{c}0.327 * * * \\
(0.105)\end{array}$ & $\begin{array}{c}0.307 * * * \\
(0.057)\end{array}$ & $\begin{array}{c}0.279 * * * \\
(0.092)\end{array}$ & $\begin{array}{c}0.066 * * * \\
(0.014)\end{array}$ & $\begin{array}{c}-0.020 * * * \\
(0.005)\end{array}$ & $\begin{array}{c}-0.086 * * * \\
(0.022)\end{array}$ & $\begin{array}{c}-0.011 * * * \\
(0.002)\end{array}$ \\
\hline Observations & 273,133 & 128,372 & 273,100 & 127,793 & 51,476 & $1,942,897$ & $1,045,004$ & $1,584,804$ \\
\hline R-squared & 0.345 & 0.302 & 0.360 & 0.295 & 0.344 & 0.202 & 0.126 & 0.093 \\
\hline Year*school FE & YES & YES & YES & YES & YES & YES & YES & YES \\
\hline Grade FE & - & - & - & - & - & YES & YES & YES \\
\hline Individual controls & YES & YES & YES & YES & YES & YES & YES & YES \\
\hline Dependent Variable (mean) & -0.035 & 0.000 & -0.021 & 0.000 & 0.771 & 0.054 & 0.217 & 0.044 \\
\hline Dependent Variable (sd) & 0.983 & 0.774 & 0.972 & 0.826 & 0.420 & 0.071 & 0.412 & 0.206 \\
\hline Futureless Language (mean) & 0.019 & 0.022 & 0.019 & 0.022 & 0.019 & 0.019 & 0.019 & 0.019 \\
\hline Futureless Language (sd) & 0.138 & 0.147 & 0.138 & 0.147 & 0.137 & 0.135 & 0.135 & 0.135 \\
\hline Futureless Language (beta) & 0.066 & 0.062 & 0.043 & 0.050 & 0.022 & -0.037 & -0.028 & -0.007 \\
\hline \multirow[t]{4}{*}{ N_clust } & 74 & 74 & 74 & 74 & 67 & 76 & 74 & 76 \\
\hline & \multicolumn{8}{|c|}{ PANEL B: 1st generation } \\
\hline & (1) & (2) & (3) & (4) & (5) & (6) & (7) & (8) \\
\hline & $\begin{array}{c}\text { Math score, } \\
\text { 3rd grade }\end{array}$ & $\begin{array}{c}\text { Math score, } \\
\text { change 3rd to } 8 \text { th }\end{array}$ & $\begin{array}{c}\text { Reading score, } \\
\text { 3rd grade }\end{array}$ & $\begin{array}{l}\text { Reading score, } \\
\text { change } 3 \text { rd to } 8 \text { th }\end{array}$ & Graduation & $\begin{array}{c}\% \text { Absent } \\
\text { Days }\end{array}$ & $\begin{array}{c}\text { Disciplinary } \\
\text { Incident }\end{array}$ & Retention \\
\hline Futureless Language (Chen) & $\begin{array}{c}0.310 * * * \\
(0.045)\end{array}$ & $\begin{array}{c}0.264 * * * \\
(0.098)\end{array}$ & $\begin{array}{c}0.130 * * * \\
(0.024)\end{array}$ & $\begin{array}{c}0.193 * * * \\
(0.061)\end{array}$ & $\begin{array}{c}0.001 \\
(0.018)\end{array}$ & $\begin{array}{c}-0.005^{*} \\
(0.003)\end{array}$ & $\begin{array}{c}-0.042^{* * *} \\
(0.008)\end{array}$ & $\begin{array}{c}-0.003 * * \\
(0.002)\end{array}$ \\
\hline Observations & 81,369 & 32,670 & 81,319 & 32,553 & 27,980 & 838,059 & 521,296 & 668,646 \\
\hline $\mathrm{R}$-squared & 0.458 & 0.413 & 0.473 & 0.422 & 0.384 & 0.188 & 0.125 & 0.108 \\
\hline Year*school FE & YES & YES & YES & YES & YES & YES & YES & YES \\
\hline Country FE & YES & YES & YES & YES & YES & YES & YES & YES \\
\hline Grade FE & - & - & - & - & - & YES & YES & YES \\
\hline Individual controls & YES & YES & YES & YES & YES & YES & YES & YES \\
\hline Dependent Variable (mean) & 0.000 & 0.000 & 0.000 & 0.000 & 0.803 & 0.050 & 0.169 & 0.036 \\
\hline Dependent Variable (sd) & 1.000 & 0.779 & 1.000 & 0.842 & 0.398 & 0.070 & 0.375 & 0.185 \\
\hline Futureless Language (mean) & 0.025 & 0.023 & 0.025 & 0.023 & 0.027 & 0.028 & 0.029 & 0.026 \\
\hline Futureless Language (sd) & 0.156 & 0.151 & 0.156 & 0.150 & 0.161 & 0.164 & 0.167 & 0.159 \\
\hline Futureless Language (beta) & 0.048 & 0.051 & 0.020 & 0.034 & 0.000 & -0.012 & -0.019 & -0.003 \\
\hline N_clust & 78 & 71 & 78 & 71 & 69 & 85 & 82 & 83 \\
\hline
\end{tabular}


Table 13 (continued)

Educational performance and alternative measures of Long-Term Orientation, FLDOE

\begin{tabular}{|c|c|c|c|c|c|c|c|c|}
\hline \multicolumn{9}{|c|}{ PANEL C: 1st generation + 2nd generation (extended definition), excluding the Americas } \\
\hline & (1) & (2) & (3) & (4) & (5) & (6) & (7) & $(8)$ \\
\hline & $\begin{array}{c}\text { Math score, } \\
\text { 3rd grade }\end{array}$ & $\begin{array}{c}\text { Math score, } \\
\text { change 3rd to } 8 \text { th }\end{array}$ & $\begin{array}{c}\text { Reading score, } \\
\text { 3rd grade }\end{array}$ & $\begin{array}{l}\text { Reading score, } \\
\text { change 3rd to } 8 \text { th }\end{array}$ & Graduation & $\begin{array}{c}\% \text { Absent } \\
\text { Days }\end{array}$ & $\begin{array}{c}\text { Disciplinary } \\
\text { Incident } \\
\end{array}$ & Retention \\
\hline Maximum Crop Yield (Galor & $\begin{array}{c}0.042 * * * \\
(0.010)\end{array}$ & $\begin{array}{c}0.030 * * * \\
(0.008)\end{array}$ & $\begin{array}{c}0.025^{* * * *} \\
(0.008)\end{array}$ & $\begin{array}{c}0.031 * * * \\
(0.008)\end{array}$ & $\begin{array}{c}0.004 * * \\
(0.002)\end{array}$ & $\begin{array}{c}-0.002 * * * \\
(0.001)\end{array}$ & $\begin{array}{c}-0.010 * * * \\
(0.002)\end{array}$ & $\begin{array}{l}-0.000 \\
(0.000)\end{array}$ \\
\hline Observations & 45,262 & 17,062 & 45,238 & 17,001 & 11,552 & 373,220 & 216,428 & 298,977 \\
\hline R-squared & 0.464 & 0.474 & 0.470 & 0.469 & 0.375 & 0.178 & 0.131 & 0.141 \\
\hline Year*school FE & YES & YES & YES & YES & YES & YES & YES & YES \\
\hline Grade FE & - & - & - & - & - & YES & YES & YES \\
\hline Individual controls & YES & YES & YES & YES & YES & YES & YES & YES \\
\hline Dependent Variable (mean) & 0.000 & 0.000 & 0.000 & 0.000 & 0.883 & 0.038 & 0.120 & 0.022 \\
\hline Dependent Variable (sd) & 1.000 & 0.764 & 1.000 & 0.834 & 0.321 & 0.062 & 0.325 & 0.147 \\
\hline Maximum Crop Yield (mean) & 8.601 & 8.610 & 8.602 & 8.607 & 8.593 & 8.593 & 8.588 & 8.592 \\
\hline Maximum Crop Yield (sd) & 2.298 & 2.261 & 2.298 & 2.263 & 2.262 & 2.298 & 2.283 & 2.281 \\
\hline Maximum Crop Yield (beta) & 0.097 & 0.089 & 0.058 & 0.085 & 0.029 & -0.089 & -0.067 & -0.004 \\
\hline N_clust & 81 & 76 & 81 & 76 & 78 & 83 & 83 & 83 \\
\hline
\end{tabular}

Notes. The table reports OLS estimates, with standard errors clustered at the language/country level. The unit of observation is a student born between 1992 and 2002 and observed during the academic years 2002-2012. In Panel A the sample pools together first generation immigrants defined using the information on both the country of origin and the language spoken at home and second generation immigrants (extended definition) defined using the information on the country of origin of the mother when available (Canada, Mexico, and Puerto Rico), or the language spoken at home for the remaining students for which the country of origin of the mother is not available. See details in the text and the appendix for how the matching between language and countries has been implemented. In Panel B the sample includes first generation immigrants defined using the information on the country of origin. Panel $\mathrm{C}$ is equal to the sample in Panel A with the exclusion of the immigrants from the American continent. The dependent variables measure students' Florida Comprehensive Assessment Test math score in grade 3 (standardized with mean 0 and variance 1), the change in math score from grade 3 to grade 8 , reading score in grade 3 (standardized with mean 0 and variance 1), change in reading score from grade 3 to grade 8 , high school graduation (a dummy for whether the student received a standard diploma within four years after entering the $9^{\text {th }}$ grade for the first time), absence rates (the percentage of days in which the student is absent during the academic year), disciplinary incidents (a dummy for whether the student was involved in a disciplinary incident, defined as serious offences often leading to suspension), and retention (an indicator for whether the student repeats the same grade at least once). All the regressions include the same individual controls described in Table 2 (coefficients not reported). In Panel A and Panel B futureless language is a dummy variable equal to 1 for "futureless" languages (languages that do not require "obligatory future time reference use in prediction-based contexts") from Chen (2013). The specification in Panel B includes country of origin fixed effects. In Panel C maximum crop yield is a historical measure of crop yield constructed based on data from the Global Agro-Ecological Zones (GAEZ) project of the Food and Agriculture Organization (FAO) and taken from Galor and Ozak (2016). We describe in details all the variables in the online Appendix. ***, **, and * indicate significance at the $1 \%, 5 \%$, and $10 \%$ levels. 


\section{Table 14}

\section{Program for International Student Assessment (PISA): sample statistics}

\begin{tabular}{|c|c|c|c|c|c|c|c|c|c|}
\hline & \multicolumn{3}{|c|}{ 1st generation } & \multicolumn{3}{|c|}{ 2nd generation (mother) } & \multicolumn{3}{|c|}{ 2nd generation (father) } \\
\hline & Obs. & Mean & St. dev. & Obs. & Mean & St. dev. & Obs. & Mean & St. dev. \\
\hline Math & 27,649 & 0.000 & 1.000 & 45,884 & 0.000 & 1.000 & 45,340 & 0.000 & 1.000 \\
\hline Reading & 27,649 & 0.000 & 1.000 & 45,884 & 0.000 & 1.000 & 45,340 & 0.000 & 1.000 \\
\hline Science & 27,649 & 0.000 & 1.000 & 45,884 & 0.000 & 1.000 & 45,340 & 0.000 & 1.000 \\
\hline Retention & 17,229 & 0.158 & 0.365 & 30,135 & 0.144 & 0.351 & 29,735 & 0.143 & 0.350 \\
\hline Truancy & 7,918 & 0.136 & 0.343 & 13,810 & 0.120 & 0.325 & 13,346 & 0.120 & 0.325 \\
\hline Male & 27,649 & 0.505 & 0.500 & 45,884 & 0.495 & 0.500 & 45,340 & 0.496 & 0.500 \\
\hline Age of student (in years) & 27,649 & 15.775 & 0.288 & 45,884 & 15.778 & 0.289 & 45,340 & 15.781 & 0.288 \\
\hline Grade 7 & 27,649 & 0.034 & 0.181 & 45,884 & 0.018 & 0.132 & 45,340 & 0.017 & 0.130 \\
\hline Grade 8 & 27,649 & 0.140 & 0.347 & 45,884 & 0.091 & 0.288 & 45,340 & 0.092 & 0.288 \\
\hline Grade 9 & 27,649 & 0.376 & 0.484 & 45,884 & 0.423 & 0.494 & 45,340 & 0.419 & 0.493 \\
\hline Grade 10 & 27,649 & 0.344 & 0.475 & 45,884 & 0.404 & 0.491 & 45,340 & 0.410 & 0.492 \\
\hline Grade 11 & 27,649 & 0.102 & 0.302 & 45,884 & 0.062 & 0.242 & 45,340 & 0.059 & 0.236 \\
\hline Grade 12 & 27,649 & 0.004 & 0.065 & 45,884 & 0.002 & 0.048 & 45,340 & 0.003 & 0.050 \\
\hline Grade 13 & 27,649 & 0.000 & 0.006 & 45,884 & 0.000 & 0.000 & 45,340 & 0.000 & 0.000 \\
\hline Parents' education level: none & 27,649 & 0.033 & 0.178 & 45,884 & 0.035 & 0.184 & 45,340 & 0.035 & 0.183 \\
\hline Parents' education level: primary & 27,649 & 0.081 & 0.272 & 45,884 & 0.084 & 0.277 & 45,340 & 0.084 & 0.277 \\
\hline Parents' education level: lower secondary & 27,649 & 0.157 & 0.364 & 45,884 & 0.186 & 0.389 & 45,340 & 0.187 & 0.390 \\
\hline Parents' education level: upper secondary & 27,649 & 0.083 & 0.275 & 45,884 & 0.105 & 0.306 & 45,340 & 0.110 & 0.313 \\
\hline Parents' education level: post-secondary non-tertiary & 27,649 & 0.200 & 0.400 & 45,884 & 0.231 & 0.421 & 45,340 & 0.229 & 0.420 \\
\hline Parents' education level: first stage of tertiary & 27,649 & 0.128 & 0.334 & 45,884 & 0.137 & 0.343 & 45,340 & 0.139 & 0.346 \\
\hline Parents' education level: second stage of tertiary & 27,649 & 0.319 & 0.466 & 45,884 & 0.223 & 0.416 & 45,340 & 0.216 & 0.412 \\
\hline Wealth & 22,734 & -0.319 & 1.049 & 39,041 & -0.241 & 0.940 & 38,033 & -0.233 & 0.934 \\
\hline
\end{tabular}

Notes. The table reports the sample statistics of the PISA sample (waves 2003, 2006, 2009 and 2012). Math, Reading and Science scores are respectively the averages of the 5 plausible values for math, reading and science tests. Retention is a dummy variable equal to 1 if a student repeated at least one year during his/her school career (PISA waves 2003, 2009 and 2012). Truancy is a dummy variable equal to 1 if the student, when asked "In the last two full weeks of school, how many times did you skip a whole school day?" ticked one of the following answers: "one or two times", "three or four times", "five or more times"; equal to 0 if s/he ticked the answer "none" (PISA wave 2012). Male is a dummy equal to one if the student is a boy. Age is the age of the student expressed in years. Grades= 7-13 are dummy variables equal to 1 if the student is in the corresponding grade. Parents' education variables are dummy variables for different level of educations (more details in the online Appendix). Wealth is an index of family wealth possessions built by OECD - PISA based on the student's responses to several questions regarding specific items in the student's home (PISA waves 2006, 2009 and 2012). More details on these variables are contained in the online Appendix. 


\section{Table 15}

\section{Long-Term Orientation and educational outcomes, PISA}

First generation immigrants

\begin{tabular}{|c|c|c|c|c|c|c|c|c|c|c|}
\hline VARIABLES & $\begin{array}{c}\text { (1) } \\
\text { Math }\end{array}$ & $\begin{array}{c}(2) \\
\text { Reading } \\
\end{array}$ & $\begin{array}{c}\text { (3) } \\
\text { Science } \\
\end{array}$ & $\begin{array}{c}\text { (4) } \\
\text { Retention }\end{array}$ & $\begin{array}{c}(5) \\
\text { Truancy } \\
\end{array}$ & $\begin{array}{c}\text { (6) } \\
\text { Math } \\
\end{array}$ & $\begin{array}{c}(7) \\
\text { Reading } \\
\end{array}$ & $\begin{array}{c}(8) \\
\text { Science } \\
\end{array}$ & $\begin{array}{c}(9) \\
\text { Retention } \\
\end{array}$ & $\begin{array}{c}(10) \\
\text { Truancy } \\
\end{array}$ \\
\hline Long-' & $\begin{array}{c}0.655^{* * *} \\
(0.155)\end{array}$ & $\begin{array}{c}0.434 * * \\
(0.213)\end{array}$ & $\begin{array}{c}0.616 * * * \\
(0.219)\end{array}$ & $\begin{array}{c}-0.065^{* *} \\
(0.027)\end{array}$ & $\begin{array}{c}-0.124 * * * \\
(0.034)\end{array}$ & $\begin{array}{c}0.709 * * * \\
(0.136)\end{array}$ & $\begin{array}{c}0.505^{* *} \\
(0.204)\end{array}$ & $\begin{array}{c}0.676 * * * \\
(0.216)\end{array}$ & $\begin{array}{c}-0.061 * * \\
(0.025)\end{array}$ & $\begin{array}{c}-0.124 * * * \\
(0.034)\end{array}$ \\
\hline Male & $\begin{array}{c}0.142^{* * *} \\
(0.011)\end{array}$ & $\begin{array}{c}-0.343^{* * *} \\
(0.026)\end{array}$ & $\begin{array}{c}0.030 \\
(0.019)\end{array}$ & $\begin{array}{c}0.017^{* * *} \\
(0.004)\end{array}$ & $\begin{array}{c}0.010 \\
(0.009)\end{array}$ & $\begin{array}{c}0.143^{* * *} \\
(0.013)\end{array}$ & $\begin{array}{c}-0.349 * * * \\
(0.026)\end{array}$ & $\begin{array}{c}0.028 \\
(0.023)\end{array}$ & $\begin{array}{c}0.013^{* *} \\
(0.006)\end{array}$ & $\begin{array}{c}0.010 \\
(0.010)\end{array}$ \\
\hline Age of student & $\begin{array}{c}-0.144 * * * \\
(0.036)\end{array}$ & $\begin{array}{c}-0.126^{* * *} \\
(0.028)\end{array}$ & $\begin{array}{c}-0.125^{* * *} \\
(0.031)\end{array}$ & $\begin{array}{c}0.190^{* * *} \\
(0.024)\end{array}$ & $\begin{array}{c}0.021 \\
(0.015)\end{array}$ & $\begin{array}{c}-0.163 * * * \\
(0.033)\end{array}$ & $\begin{array}{c}-0.154 * * * \\
(0.030)\end{array}$ & $\begin{array}{c}-0.155^{* * *} \\
(0.033)\end{array}$ & $\begin{array}{c}0.193^{* * *} \\
(0.028)\end{array}$ & $\begin{array}{c}0.021 \\
(0.015)\end{array}$ \\
\hline Wealth & & & & & & $\begin{array}{c}0.048^{* * *} \\
(0.017)\end{array}$ & $\begin{array}{c}0.031^{* *} \\
(0.014)\end{array}$ & $\begin{array}{c}0.027^{* *} \\
(0.012)\end{array}$ & $\begin{array}{l}-0.000 \\
(0.004)\end{array}$ & $\begin{array}{c}0.004 \\
(0.004)\end{array}$ \\
\hline Observations & 27,649 & 27,649 & 27,649 & 17,229 & 7,918 & 22,734 & 22,734 & 22,734 & 13,371 & 7,899 \\
\hline $\mathrm{R}$-squared & 0.371 & 0.341 & 0.341 & 0.314 & 0.080 & 0.380 & 0.344 & 0.348 & 0.337 & 0.081 \\
\hline Year FE & YES & YES & YES & YES & - & YES & YES & YES & YES & - \\
\hline Grade FE & YES & YES & YES & YES & YES & YES & YES & YES & YES & YES \\
\hline Parents' education FE & YES & YES & YES & YES & YES & YES & YES & YES & YES & YES \\
\hline Country of destination FE & YES & YES & YES & YES & YES & YES & YES & YES & YES & YES \\
\hline Dependent Variable (mean) & 0.000 & 0.000 & 0.000 & 0.158 & 0.136 & 0.000 & 0.000 & 0.000 & 0.159 & 0.136 \\
\hline Dependent Variable (sd) & 1.000 & 1.000 & 1.000 & 0.365 & 0.343 & 1.000 & 1.000 & 1.000 & 0.366 & 0.343 \\
\hline Long-Term Orientation (mean) & 0.590 & 0.590 & 0.590 & 0.570 & 0.561 & 0.591 & 0.591 & 0.591 & 0.566 & 0.561 \\
\hline Long-Term Orientation (sd) & 0.253 & 0.253 & 0.253 & 0.259 & 0.267 & 0.258 & 0.258 & 0.258 & 0.268 & 0.266 \\
\hline Long-Term Orientation (beta) & 0.166 & 0.110 & 0.156 & -0.046 & -0.097 & 0.183 & 0.131 & 0.175 & -0.045 & -0.097 \\
\hline N_clust & 63 & 63 & 63 & 63 & 54 & 58 & 58 & 58 & 52 & 54 \\
\hline
\end{tabular}

Notes. The table reports OLS estimates, with standard errors clustered at the country of origin level. The unit of observation is a first generation immigrant student from one of the 63 countries residing in one of the 37 countries surveyed in PISA for which information about country of origin of the respondent is available (4 waves from 2003 to 2012 depending on whether the variables used in the regression are all available - details are in the online Appendix). The dependent variables are Math, Reading, and Science scores calculated according to the description on the online appendix, retention (a dummy variable equal to 1 if a student repeated at least one year during his/her school career), and truancy (a dummy variable equal to 1 if the student skipped at least one full day of school in the previous two weeks). The "Long Term Orientation" variable is based on Hofstede (2010) and is measured on a 0-1 scale. Individual controls are: male (a dummy equal to one if the student is a boy), age (the age of the student expressed in years), dummies for student grade and for parents' education, wealth (an index of family wealth possessions built by OECD - PISA). We describe in details all the variables (and their availability in different PISA waves) in the online Appendix. ***, **, and * indicate significance at the 1\%, 5\%, and $10 \%$ levels. 


\section{Table 16}

\section{Long-Term Orientation and educational outcomes, PISA Second generation immigrants (maternal side)}

\begin{tabular}{|c|c|c|c|c|c|c|c|c|c|c|}
\hline & (1) & (2) & (3) & (4) & (5) & (6) & (7) & (8) & (9) & (10) \\
\hline VARIABLES & Math & Reading & Science & Retention & Truancy & Math & Reading & Science & Retention & Truancy \\
\hline \multirow[t]{2}{*}{ Long-Term Orientation } & $0.745^{* * *}$ & $0.680 * * *$ & $0.808 * * *$ & $-0.081 * * *$ & $-0.081 * *$ & $0.787 * * *$ & $0.725 * * *$ & $0.855 * * *$ & $-0.080 * * *$ & $-0.082 * *$ \\
\hline & $(0.201)$ & $(0.193)$ & $(0.206)$ & $(0.024)$ & $(0.036)$ & $(0.195)$ & $(0.192)$ & $(0.203)$ & $(0.023)$ & $(0.035)$ \\
\hline \multirow[t]{2}{*}{ Male } & $0.193^{* * *}$ & $-0.322 * * *$ & $0.079 * * *$ & 0.007 & -0.009 & $0.197 * * *$ & $-0.323 * * *$ & $0.078^{* * *}$ & 0.006 & -0.009 \\
\hline & $(0.017)$ & $(0.036)$ & $(0.019)$ & $(0.007)$ & $(0.010)$ & $(0.018)$ & $(0.036)$ & $(0.021)$ & $(0.007)$ & $(0.010)$ \\
\hline \multirow[t]{2}{*}{ Age of student } & $-0.216^{* * *}$ & $-0.196 * * *$ & $-0.172 * * *$ & $0.272^{* * *}$ & $0.030^{* *}$ & $-0.220 * * *$ & $-0.200^{* * *}$ & $-0.180^{* * *}$ & $0.293^{* * *}$ & $0.030^{* *}$ \\
\hline & $(0.033)$ & $(0.036)$ & $(0.034)$ & $(0.035)$ & $(0.014)$ & $(0.035)$ & $(0.040)$ & $(0.039)$ & $(0.032)$ & $(0.014)$ \\
\hline \multirow[t]{2}{*}{ Wealth } & & & & & & 0.006 & -0.008 & -0.018 & 0.001 & 0.005 \\
\hline & & & & & & $(0.014)$ & $(0.012)$ & $(0.012)$ & $(0.004)$ & $(0.006)$ \\
\hline Observations & 45,884 & 45,884 & 45,884 & 30,135 & 13,810 & 39,041 & 39,041 & 39,041 & 24,292 & 13,775 \\
\hline $\mathrm{R}$-squared & 0.382 & 0.348 & 0.354 & 0.483 & 0.108 & 0.393 & 0.356 & 0.362 & 0.492 & 0.108 \\
\hline Year FE & YES & YES & YES & YES & - & YES & YES & YES & YES & - \\
\hline Grade FE & YES & YES & YES & YES & YES & YES & YES & YES & YES & YES \\
\hline Parents' education FE & YES & YES & YES & YES & YES & YES & YES & YES & YES & YES \\
\hline Country of destination FE & YES & YES & YES & YES & YES & YES & YES & YES & YES & YES \\
\hline Dependent Variable (mean) & 0.000 & 0.000 & 0.000 & 0.144 & 0.120 & 0.000 & 0.000 & 0.000 & 0.154 & 0.120 \\
\hline Dependent Variable (sd) & 1.000 & 1.000 & 1.000 & 0.351 & 0.325 & 1.000 & 1.000 & 1.000 & 0.361 & 0.325 \\
\hline Long-Term Orientation (mean) & 0.646 & 0.646 & 0.646 & 0.643 & 0.631 & 0.647 & 0.647 & 0.647 & 0.642 & 0.631 \\
\hline Long-Term Orientation (sd) & 0.227 & 0.227 & 0.227 & 0.227 & 0.231 & 0.231 & 0.231 & 0.231 & 0.233 & 0.231 \\
\hline Long-Term Orientation (beta) & 0.169 & 0.155 & 0.184 & -0.052 & -0.058 & 0.182 & 0.168 & 0.198 & -0.052 & -0.059 \\
\hline N_clust & 60 & 60 & 60 & 58 & 56 & 58 & 58 & 58 & 53 & 56 \\
\hline
\end{tabular}

Notes. The table reports OLS estimates, with standard errors clustered at the country of origin level. The unit of observation is a second generation immigrant student on the maternal side from one of the 63 countries residing in one of the 37 countries surveyed in PISA for which information about the country of origin of the parents is available (4 waves from 2003 to 2012 depending on whether the variables used in the regression are all available - details are on the online Appendix). The dependent variables are Math, Reading, Science scores calculated according to the description on the online appendix, retention (a dummy variable equal to 1 if a student repeated at least one year during his/her school career), and truancy (a dummy variable equal to 1 if the student skipped at least one full day of school in the previous two weeks). The "Long Term Orientation" variable is based on Hofstede (2010) and is measured on a 0-1 scale. Individual controls are: male (a dummy equal to one if the student is a boy), age (the age of the student expressed in years), dummies for student grade and for parents' education, wealth (an index of family wealth possessions built by OECD - PISA). We describe in details all the variables (and their availability in different PISA waves) on the online Appendix. ***, **, and * indicate significance at the $1 \%$, $5 \%$, and $10 \%$ levels. 
Web Appendix for

\title{
Long-Term Orientation and Educational Performance
}

\author{
David Figlio
}

Northwestern University and NBER

Paola Giuliano

UCLA and NBER

Umut Ozek

American Institutes for Research

Paola Sapienza

Northwestern University and NBER

(NOT FOR PUBLICATION)

AUGUST 2016 


\section{A1. Introduction}

This appendix accompanies "Long Term Orientation and Educational Performance" by David Figlio, Paola Giuliano, Umut Ozek, and Paola Sapienza. Section A2 provides further details of the data used in the paper, as well as the definition of variables. Section A3 reports additional tables discussed in the body of the paper, but not reported there explicitly.

\section{A2. Data and Their Sources}

In this section we describe in more details of some of the variables used in the analysis. We also describe some additional technical details to understand the construction of the data and the regression analysis.

\section{A.2.1. Long-Term Orientation}

Hofstede et al. (2010) constructed the measure of Long-Term Orientation through a factor analysis of the following variables, taken from the WVS (latest data available for each country in the 1995-2004 period): 1. Thrift as a desirable trait for children (percentage of people in a country choosing "thrift" as one of the answers to the question: "Here is a list of qualities that children can be encouraged to learn at home. Which, if any, do you consider to be especially important? Please choose up to five." The list included: independence, hard work, feeling of responsibility, imagination, tolerance and respect for other people, thrift (saving money and things), determination (perseverance), religious faith, unselfishness, obedience.) 2. National pride (percentage of people in a country choosing "very proud" as answer to the following question: "How proud are you to be name of your nationality-?" Possible answers included: "very proud," "quite proud," "not very proud," "not at all proud") 3. Importance of service to others (percentage of people in each country choosing "very important" as answer to the following question: "For each of the following, indicate how important it is in your life_-very important, rather important, not very important, or not at all important: family, friends, leisure time, politics, work, religion, service to others." We downloaded the actual variable from the website www.geerthofstede.nl/dimensiondata-matrix in the spreadsheet "Six dimensions for website.xls (version 201512 08)" with the addition of the data "NonOfficial VSM08 scores" for Nepal and Sri Lanka, for which we take the value corresponding to "Sri Lanka-General population." The Long-Term Orientation variable ranges from 0 to 100 . In our data it was rescaled as a $0-1$ variable.

\footnotetext{
${ }^{1}$ Because service to others had some missing values, linear regression on the two other variables was used to predict the missing factor scores.
} 


\section{A.2.2. Description of variables for the Florida analysis}

\begin{tabular}{|c|c|c|}
\hline \multicolumn{3}{|c|}{ Dependent variables } \\
\hline Name of the variable & Description & $\begin{array}{l}\text { Source (and when possible and useful name of } \\
\text { the raw variable) }\end{array}$ \\
\hline Math score & $\begin{array}{l}\text { Development scale score in the Mathematics } \\
\text { section of the FCAT. The scores are standardized } \\
\text { by subtracting the mean test score in the sample } \\
\text { used for the analysis and by dividing them by the } \\
\text { standard deviation in the sample, for each test grade } \\
\text { level-year combination. }\end{array}$ & $\begin{array}{l}\text { Source: FLDOE } \\
\text { Created using raw variables: } \\
\text { DEV_SCALE_SCORE, } \\
\text { SUBTEST_ID, } \\
\text { TEST_GRADE_LEVEL, } \\
\text { CURRENT_ACADEMIC_YEAR }\end{array}$ \\
\hline $\begin{array}{l}\text { Math score, change } \\
3^{\text {rd }} \text { to } 8^{\text {th }}\end{array}$ & $\begin{array}{l}\text { Difference between the standardized math score in } \\
\text { grade } 8 \text { and the standardized math score in grade } 3 \text {. } \\
\text { The standardization is done within each sample by } \\
\text { subtracting the mean test score in the sample (for } \\
\text { each grade) and by dividing them by the sample } \\
\text { standard deviation. }\end{array}$ & $\begin{array}{l}\text { Source: FLDOE } \\
\text { Created using raw variables: } \\
\text { DEV_SCALE_SCORE, } \\
\text { SUBTEST_ID, } \\
\text { TEST_GRADE_LEVEL, } \\
\text { CURRENT_ACADEMIC_YEAR }\end{array}$ \\
\hline Reading score & $\begin{array}{l}\text { Development scale score in the Reading section of } \\
\text { the FCAT. The scores are standardized by } \\
\text { subtracting the mean test score in the sample used } \\
\text { for the analysis and by dividing them by the } \\
\text { standard deviation in the sample, for each test grade } \\
\text { level-year combination. }\end{array}$ & $\begin{array}{l}\text { Source: FLDOE } \\
\text { Created using raw variables: } \\
\text { DEV_SCALE_SCORE, } \\
\text { SUBTEST_ID, } \\
\text { TEST_GRADE_LEVEL, } \\
\text { CURRENT_ACADEMIC_YEAR }\end{array}$ \\
\hline $\begin{array}{l}\text { Reading score, } \\
\text { change } 3^{\text {td }} \text { to } 8^{\text {th }}\end{array}$ & $\begin{array}{l}\text { Difference between the standardized reading score } \\
\text { in grade } 8 \text { and the standardized reading score in } \\
\text { grade } 3 \text {. The standardization is done within each } \\
\text { sample by subtracting the mean test score in the } \\
\text { sample (for each grade) and by dividing them by the } \\
\text { sample standard deviation. }\end{array}$ & $\begin{array}{l}\text { Source: FLDOE } \\
\text { Created using raw variables: } \\
\text { DEV_SCALE_SCORE, } \\
\text { SUBTEST_ID, } \\
\text { TEST_GRADE_LEVEL, } \\
\text { CURRENT_ACADEMIC_YEAR }\end{array}$ \\
\hline Graduation & $\begin{array}{l}\text { Dummy variable equal to } 1 \text { if a student obtained a } \\
\text { standard diploma within } 4 \text { years after entering grade } \\
9 \text { for the first time. }\end{array}$ & $\begin{array}{l}\text { Source: FLDOE } \\
\text { Created using raw variables: } \\
\text { ENROLLMENT_YEAR, } \\
\text { WITHDRAWAL_REASON_CD, } \\
\text { GRADE_LVL_ID }\end{array}$ \\
\hline$\%$ Absent Days & $\begin{array}{l}\text { Percentage of absent days during the year calculated } \\
\text { as a fraction of absent days over the sum of absent } \\
\text { and present days. }\end{array}$ & $\begin{array}{l}\text { Source: FLDOE } \\
\text { Created using raw variables: } \\
\text { ABSENT_DAYS_NBR, } \\
\text { PRESENT_DAYS_NBR }\end{array}$ \\
\hline $\begin{array}{l}\text { Disciplinary } \\
\text { Incident }\end{array}$ & $\begin{array}{l}\text { Dummy variable equal to } 1 \text { if the student was } \\
\text { involved in a disciplinary incident during the year, } \\
\text { equal to } 0 \text { if } \mathrm{s} / \text { he was not involved in any } \\
\text { disciplinary incident. A disciplinary incident is a } \\
\text { serious offense that usually results in suspension. }\end{array}$ & $\begin{array}{l}\text { Source: FLDOE } \\
\text { Created using raw variables: } \\
\text { STUDENT_REFERRAL_ACTION_ } \\
\text { CD }\end{array}$ \\
\hline Retention & $\begin{array}{l}\text { Dummy variable equal to } 1 \text { in year } t \text { if the student } \\
\text { attends the same grade in year } t \text { and in year } t+1 \text {, and } \\
\text { equal to } 0 \text { if the student attends a higher grade in } \\
\text { year } t+1 \text {. }\end{array}$ & $\begin{array}{l}\text { Source: FLDOE } \\
\text { Created using raw variables: } \\
\text { ENROLLMENT_YEAR, } \\
\text { GRADE_LVL_ID }\end{array}$ \\
\hline
\end{tabular}




\begin{tabular}{|c|c|c|}
\hline Gifted in grade 4 & $\begin{array}{l}\text { Dummy variable equal to } 1 \text { if the student is } \\
\text { classified as gifted in grade } 4 \text { and zero otherwise. }\end{array}$ & $\begin{array}{l}\text { Source: FLDOE } \\
\text { Created using raw variables: } \\
\text { PRIMARY_EXCPT_IND }\end{array}$ \\
\hline $\begin{array}{l}\text { School letter score } \\
\text { at year } t-1\end{array}$ & $\begin{array}{l}\text { School letter scores are recoded into a numerical } \\
\text { scale ranging from } 1 \text { to } 5 \text {, where a letter grade of } \\
\text { "F" corresponds to } 1 \text {, "D" corresponds to } 2 \text {, "C" } \\
\text { corresponds to } 3 \text {, "B" corresponds to } 4 \text {, "A" } \\
\text { corresponds to } 5 \text {. We assign to each school the } \\
\text { score it earned in year } t-1 \text {, that is the year before the } \\
\text { student attends the school. Source: } \\
\text { http:// schoolgrades.fldoe.org (we took the } \\
\text { information from the } 2013-2014 \text { School Grades } \\
\text { spreadsheet) }\end{array}$ & $\begin{array}{l}\text { Source: FLDOE } \\
\text { Created using raw variables: School } \\
\text { grade variable in the 2013-14 school } \\
\text { grades spreadsheet. }\end{array}$ \\
\hline $\begin{array}{l}\text { Fraction of } \\
\text { advanced classes }\end{array}$ & $\begin{array}{l}\text { Number of IB, AICE or AP classes taken during } \\
\text { the academic year over the total number of classes } \\
\text { taken. Advanced classes are identified using } \\
\text { FLDOE's course code directory for each school } \\
\text { year } \\
\text { (http://www.fldoe.org/policy/articulation/ccd). }\end{array}$ & $\begin{array}{l}\text { Source: FLDOE } \\
\text { Created using raw variables: } \\
\text { COURSE_NUMBER }\end{array}$ \\
\hline $\begin{array}{l}\text { Fraction of } \\
\text { advanced classes } \\
\text { (scientific subjects) }\end{array}$ & $\begin{array}{l}\text { Number of IB, AICE or AP classes taken during } \\
\text { the academic year in Math, Computer Science, or } \\
\text { Natural Sciences over the total number of classes } \\
\text { taken. More specifically, "Scientific advanced } \\
\text { classes" are all those classes whose course numbers } \\
\text { are between } 200000-300000 \text { (Computer Science), } \\
1200000-1300000 \text { (Mathematics) or } 2000000- \\
2100000 \text { (Sciences: Biology, Environmental } \\
\text { Sciences, Chemistry, Physics and Design } \\
\text { Technology). Source: } \\
\text { http://www.fldoe.org/policy/articulation/ccd/arch } \\
\text { ive/2005-2006-course-directory.stml }\end{array}$ & $\begin{array}{l}\text { Source: FLDOE } \\
\text { Created using raw variables: } \\
\text { COURSE_NUMBER }\end{array}$ \\
\hline \multicolumn{3}{|l|}{ Individual controls } \\
\hline Name of the variable & Description & Source \\
\hline Age in months & $\begin{array}{l}\text { Assuming the school year starts on Sep 1st, the } \\
\text { variable is calculated as: Academic year*12+8- } \\
\text { Student year of birth*12-student month of birth. }\end{array}$ & $\begin{array}{l}\text { Source: FLDOE } \\
\text { Created using raw variables: } \\
\text { STUDENT_BIRTH_MONTH, } \\
\text { STUDENT_BIRTH_YEAR, } \\
\text { ENROLLMENT_YEAR }\end{array}$ \\
\hline Male & A dummy for whether the student is a boy. & $\begin{array}{l}\text { Source: FLDOE } \\
\text { Created using raw variables: } \\
\text { GENDER_CD }\end{array}$ \\
\hline $\begin{array}{l}\text { Free or Reduced } \\
\text { Priced Lunch }\end{array}$ & $\begin{array}{l}\text { A dummy equal to } 1 \text { if the student/year is eligible } \\
\text { for free lunch, reduced-price lunch or attends a } \\
\text { "provision 2" school and zero otherwise (either the } \\
\text { student did not apply or he/she applied but she/he } \\
\text { was not eligible). }\end{array}$ & $\begin{array}{l}\text { Source: FLDOE } \\
\text { Created using raw variables: } \\
\text { LUNCH_STATUS }\end{array}$ \\
\hline $\begin{array}{l}\text { Enrolled in Limited } \\
\text { English proficiency } \\
\text { program }\end{array}$ & $\begin{array}{l}\text { A dummy variable equal to } 1 \text { if the student is } \\
\text { enrolled in a limited English proficiency program } \\
\text { and zero otherwise. }\end{array}$ & $\begin{array}{l}\text { Source: FLDOE } \\
\text { Created using raw variables: } \\
\text { LIMITED_ENGLISH_PROFIENC }\end{array}$ \\
\hline
\end{tabular}




\begin{tabular}{|c|c|c|}
\hline & & Y_CD \\
\hline Special Education & $\begin{array}{l}\text { A dummy variable equal to } 1 \text { if the variable if the } \\
\text { student has special education needs and zero } \\
\text { otherwise. Gifted students are classified as zero. }\end{array}$ & $\begin{array}{l}\text { Source: FLDOE } \\
\text { Created using raw variables: } \\
\text { PRIMARY_EXCPT_IND }\end{array}$ \\
\hline $\begin{array}{l}\text { Mother's } \\
\text { educational } \\
\text { dummies }\end{array}$ & $\begin{array}{l}\text { We define three dummies for the maternal level of } \\
\text { education: high school graduate (years of education } \\
\text { is equal to 12), some college (years of education } \\
\text { greater than } 12 \text { and strictly smaller than 16) and } \\
\text { college graduate (years of education greater or equal } \\
\text { than 16). The mother's years of education variable } \\
\text { is taken from the birth certificates. }\end{array}$ & Source: birth certificate \\
\hline $\begin{array}{l}\text { Mother teen } \\
\text { pregnancy }\end{array}$ & $\begin{array}{l}\text { A dummy equal to } 1 \text { if mother's age at time of birth } \\
\text { is smaller or equal than } 16 \text { years, equal to } 0 \text { if it is } \\
\text { greater than } 16 \text { years. Mother's age at time of birth } \\
\text { is constructed starting from mother's month and } \\
\text { year of birth (both provided in the birth certificate) } \\
\text { and children's month and year of birth (provided by } \\
\text { FLDOE). Mother's age is set to missing if it is less } \\
\text { than } 12 \text { or greater than } 50 \text {. This variable is obtained } \\
\text { from the birth certificates. }\end{array}$ & Source: birth certificate \\
\hline $\begin{array}{l}\text { Mother married at } \\
\text { time of birth }\end{array}$ & $\begin{array}{l}\text { A dummy variable equal to } 1 \text { if the mother is } \\
\text { married at time of giving birth. }\end{array}$ & Source: birth certificate \\
\hline $\begin{array}{l}\text { Number of older } \\
\text { siblings }\end{array}$ & $\begin{array}{l}\text { The number of older siblings. This variable is } \\
\text { obtained from the birth certificates. }\end{array}$ & Source: birth certificate \\
\hline $\begin{array}{l}\text { Median income in } \\
\text { zip code of birth, } \\
(100,000 \text { of } \$)\end{array}$ & $\begin{array}{l}\text { We match the zip code at time of birth (provided } \\
\text { by the birth certificates) with zip code income in } \\
\text { 1999, obtained from the Census bureau. }\end{array}$ & Source: birth certificate and Census \\
\hline $\begin{array}{l}\text { Fraction speaking } \\
\text { the same language } \\
(\log )\end{array}$ & $\begin{array}{l}\text { Number of students who speak the same language } \\
\text { of the student over total number of students in the } \\
\text { school she/he attends, in the given year, multiplied } \\
\text { by } 100 \text {, of which we then computed the logarithm. }\end{array}$ & $\begin{array}{l}\text { Source: FLDOE } \\
\text { Created using raw variables: } \\
\text { LANGUAGE_HAVE_PARENTS_S } \\
\text { PEAKING, INSTITUTION_ID, } \\
\text { ENROLLMENT_YEAR }\end{array}$ \\
\hline $\begin{array}{l}\text { Continent } \\
\text { dummies }\end{array}$ & $\begin{array}{l}\text { In Table } 9 \text { we pooled together first and extended } \\
\text { version of second generation immigrants and test } \\
\text { the robustness of the results to the exclusion of the } \\
\text { Latin American continent and the Asian continent. } \\
\text { Since we merge immigrants using both a definition } \\
\text { based on the country of origin and definition based } \\
\text { on the language, the continent dummy needs to } \\
\text { combine both elements. For first generation the } \\
\text { dummy is equal to one if the country belongs to a } \\
\text { given continent. As for language, we adopted the } \\
\text { following rule: a language is assigned to a given } \\
\text { continent if among the sample of } 1 \text { st generation } \\
\text { migrants who speak that language (and from which } \\
\text { we built the weights), at least } 50 \% \text { come from that } \\
\text { specific continent. For instance, in the case of } \\
\text { Portuguese, if among the first generation migrants } \\
60 \% \text { of the Portuguese speakers come from Brazil } \\
\text { and } 40 \% \text { come from Portugal, the language-level }\end{array}$ & $\begin{array}{l}\text { Source: FLDOE } \\
\text { Created using raw variables: } \\
\text { LANGUAGE_HAVE_PARENTS_S } \\
\text { PEAKING } \\
\text { COUNTRY_CD_BORNED_IN }\end{array}$ \\
\hline
\end{tabular}




\begin{tabular}{|c|c|c|}
\hline & $\begin{array}{l}\text { continent dummy assigned to Portuguese will be } \\
\text { "Americas". Note that we define "Latin America" } \\
\text { as all countries located in the Americas with the } \\
\text { exclusion of Canada and the US. }\end{array}$ & \\
\hline \multicolumn{2}{|l|}{ Country controls } & \\
\hline Name of the variable & Description & Source \\
\hline $\begin{array}{l}\text { Distance from the } \\
\text { US (log) }\end{array}$ & $\begin{array}{l}\text { Log (distance in } \mathrm{km} \text { ) between the most populated } \\
\text { city in the country of origin of the immigrant and } \\
\text { the most populated city in the United States. For } \\
\text { Serbia and Montenegro, we use the value assigned } \\
\text { to "Yugoslavia." }\end{array}$ & $\begin{array}{l}\text { Source: } \\
\text { http://www.cepii.fr/CEPII/en/bdd_ } \\
\text { modele/presentation.asp?id=6 }\end{array}$ \\
\hline $\begin{array}{l}\text { Log GDP pc year } \\
2000, \text { ppp }\end{array}$ & $\begin{array}{l}\text { Log per capita GDP (PPP converted relative to the } \\
\text { United States, G-K method, at current prices) for } \\
\text { the year } 2000 \text {. We take the logarithm of this } \\
\text { value }+1 \text {. }\end{array}$ & $\begin{array}{l}\text { Source: } \\
\text { http://www.rug.nl/research/ggdc/dat } \\
\underline{\text { a/pwt/pwt-7.0 }}\end{array}$ \\
\hline $\begin{array}{l}\text { Mean PISA score } \\
\text { in Math }\end{array}$ & $\begin{array}{l}\text { Mean score in Mathematics (weighted average using } \\
\text { population weights of the individual values, } \\
\text { calculated as averages of the } 5 \text { Plausible Values } \\
\text { provided in the dataset). Average across all available } \\
\text { years ( } 2003 \text { to 2012) for the given country. }\end{array}$ & Source: https://www.oecd.org/pisa/ \\
\hline $\begin{array}{l}\text { Education selection } \\
\text { to Florida }\end{array}$ & $\begin{array}{l}\text { Calculated as the net difference index used by } \\
\text { Feliciano (2005) and proposed by Lieberson (1976). } \\
\text { It is a comparative measure of immigrants' and } \\
\text { non-immigrants' educational attainment (adjusted } \\
\text { for age) along several points of the education } \\
\text { distribution (no schooling; primary education; } \\
\text { secondary education; tertiary education). For the } \\
\text { exact formula see Feliciano (2005). Educational } \\
\text { attainment of the migrants is obtained from the } \\
\text { Census } 2000 \text {, looking at } 1 \text { st generation migrants } \\
\text { aged } 25 \text { years old or older, who live in Florida, and } \\
\text { who migrated to the US at an age equal or higher } \\
\text { than } 18 \text { years old } \\
\text { The educational attainment from the country of } \\
\text { origin is taken from Barro-Lee ("Educational } \\
\text { Attainment Data For The Population Aged } 25 \\
\text { Years And Older) and it is augmented with data for } \\
\text { Puerto Rico obtained from UNESCO for year } \\
2012 \text {. }\end{array}$ & $\begin{array}{l}\text { Sources: www.ipums.org, } \\
\text { http://data.uis.unesco.org; } \\
\underline{\text { http://www.barrolee.com }}\end{array}$ \\
\hline $\begin{array}{l}\text { Savings over } \\
\text { GDP/100 }\end{array}$ & Savings rate/GDP for the year 2000 . & $\begin{array}{l}\text { Source: } \\
\text { http://data.worldbank.org/indicator/ } \\
\text { NY.GDS.TOTL.ZS }\end{array}$ \\
\hline $\begin{array}{l}\text { Maximum Crop } \\
\text { Yield (Galor) }\end{array}$ & $\begin{array}{l}\text { A historical measure of crop yield constructed } \\
\text { based on data from the Global Agro-Ecological } \\
\text { Zones (GAEZ) project of the Food and Agriculture } \\
\text { Organization (FAO). The measure is constructed } \\
\text { under low level of inputs and rain-fed agriculture. } \\
\text { For details see Galor et Ozak (2016). }\end{array}$ & $\begin{array}{l}\text { Source: http://ozak.github.io/Caloric- } \\
\text { Suitability-Index/ } \\
\text { Created using the variable: } \\
\text { post1500maximumcalories0mean_aa } \\
\text { divided by } 1,000\end{array}$ \\
\hline
\end{tabular}




\begin{tabular}{|l|l|l|}
\hline $\begin{array}{l}\text { Futureless } \\
\text { Language (Chen) }\end{array}$ & $\begin{array}{l}\text { Dummy variable equal to } 1 \text { for "futureless" } \\
\text { languages (languages that do not require "obligatory } \\
\text { use in prediction-based contexts"). We recoded } \\
\text { Chen (2013) accordingly. }\end{array}$ & $\begin{array}{l}\text { Source: } \\
\text { http://www.anderson.ucla.edu/faculty } \\
\text { /keith.chen/datafilm.htm. } \\
\text { Created using the raw variable: } \\
\text { prediction_ftr }\end{array}$ \\
\hline
\end{tabular}

\section{A.2.3 Description of the samples in Florida Analysis and other technical details}

Sample of first generation immigrants. In our regressions we use two samples of first generation immigrants. For the first sample, we define this group using the country of origin of the children. For the second sample, we define this group using the country of origin of the children and also impose the additional restriction that they speak at home one of the main languages spoken in their country of birth (the list of the main languages spoken in a country is taken from the 17th version of the Ethnologue.)

Sample of second generation immigrants: We use two samples of second generation immigrants. The first one includes US born children whose mothers were born abroad. In the birth certificates of children born in Florida it is indicated whether the mother is born in the US or abroad. For a subset of countries or territories (Canada, Cuba, Guam, Mexico, Puerto Rico, US, and Virgin Islands) the place of birth of the mother is also indicated. ${ }^{2}$ For all the other foreign born mothers we know the mother was born abroad but do not have a country of birth. To construct the sample of second generation immigrants we use the information on the country of origin of the mother when available (Mexico, Puerto Rico and Canada) or the language spoken at home for individuals whose mother was born abroad but we do not have a country of origin. As we have birth certificates only for children born in Florida and the maternal place of birth is listed in the birth certificates, this group includes only children born in Florida. The second sample includes the group defined above along with all children born in the US (including children born outside Florida) and who speak a language different than English at home. ${ }^{3}$ We refer to the former sample

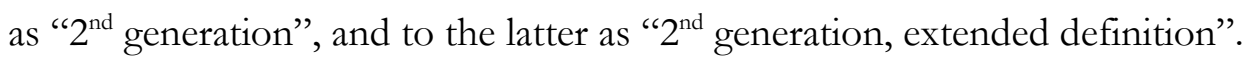

Matching languages and countries. For some students to identify the country of origin we use the language spoken at home. To create a match between languages and countries of origin we

\footnotetext{
${ }^{2}$ We use the information of the foreign countries or territories only for mothers born in Canada, Mexico, and Puerto Rico for which we have the Long Term Orientation variable. We drop all the students whose mothers are born in Cuba, Guam, and Virgin Islands and speak a language associated with these countries. ${ }^{3}$ This second sample of extended generation students can be second generation immigrants on the mother side if they are born outside Florida or on the father side, or they can be third generation immigrants.
} 
proceed as follows. For most languages there is a one to one association between language and country of origin. For languages spoken in multiple countries (for example Portuguese) we calculate the Long-Term Orientation cultural variable as a weighted average of the Long-Term Orientation of all the countries in which Portuguese is the main language spoken in the country. We use as weights the fraction of first generation immigrants in our sample speaking that language and born in a country where the language is indeed one of the spoken languages.

Construction of the clusters for standard errors. In all the regression we cluster the standard errors to account for correlation within the country of origin/language depending on whether we attribute the Hofstede variable using country of origin or language of origin. When we pool together first and second generation in the same regression to create parsimonious clusters and to avoid creating a separate cluster country and language (for example "China" and "Chinese") we use the following methodology. Whenever at least $60 \%$ of the 1 st generation speakers of a given language come from one specific country, we attribute that language to the cluster dimension corresponding to that country. This happens in all cases but for Arabic, Croatian, French, and Spanish (when we are not able to identify the country of origin to the mother). In these cases, since it would be hard to map the language to a unique country of origin, we treat these languages as having their own cluster.

\section{A.2.2. Description of variables for the Program for International Student Assessment}

In reporting the test score in mathematics, reading and science, PISA assigns a probability distribution to each possible response pattern in each test to describe the ability associated with that pattern. From this distribution, PISA draws a set of five values associated with each student. These values are called plausible values because they represent alternative estimates of the student ability that could have been obtained. In our specification, we report the regressions for the average of the plausible values. We cluster the standard errors by country of origin. We also test the robustness of our results to the procedure recommended by the OECD, where we estimate one regression for each set of plausible values and report the arithmetic average of these estimates. For this procedure, we also apply the Fay's Balanced Repeated Replicated methodology, which estimates the standard errors taking into account PISA's stratified, two-stage sample design. ${ }^{4}$

\footnotetext{
4 PISA's stratification consists in selecting randomly the school in the first stage. In the second stage, students in each school are randomly assigned to carry out the test in all three subjects.
} 


\begin{tabular}{|c|c|c|}
\hline \multicolumn{3}{|c|}{ Dependent variables } \\
\hline Name of the variable & Description & Source \\
\hline Math score & $\begin{array}{l}\text { Average of the } 5 \text { plausible values for Math. } \\
\text { This variable is present in the 2003, 2006, 2009, } \\
\text { and } 2012 \text { PISA waves. }\end{array}$ & $\begin{array}{l}\text { Created using variables } \\
\text { PVMATH1 through } \\
\text { PVMATH5 }\end{array}$ \\
\hline Reading score & $\begin{array}{l}\text { Average of the } 5 \text { plausible values for Reading. } \\
\text { This variable is present in the 2003, 2006, 2009, } \\
\text { and } 2012 \text { PISA waves. }\end{array}$ & $\begin{array}{l}\text { Created using variables } \\
\text { PVREAD1 through } \\
\text { PVREAD5 }\end{array}$ \\
\hline Science score & $\begin{array}{l}\text { Average of the } 5 \text { plausible values for Science. } \\
\text { This variable is present in the 2003, 2006, 2009, } \\
\text { and } 2012 \text { PISA waves. }\end{array}$ & $\begin{array}{l}\text { Created using variables } \\
\text { PVSCIE1 through PVSCIE5 }\end{array}$ \\
\hline Retention & $\begin{array}{l}\text { A dummy variable equal to } 1 \text { if a student } \\
\text { repeated at least one year during his/her school } \\
\text { career. This variable is present in the 2003, } \\
\text { 2009, and } 2012 \text { PISA waves. }\end{array}$ & $\begin{array}{l}\text { It is calculated starting from } \\
\text { questions ST22Q01, ST22Q02 } \\
\text { and ST22Q03 in wave 2003, } \\
\text { questions ST07Q01, } \\
\text { ST07Q02, ST07Q03 in wave } \\
\text { 2009, questions ST07Q01, } \\
\text { ST07Q02, ST07Q03 in wave } \\
\text { 2012 }\end{array}$ \\
\hline Truancy & $\begin{array}{l}\text { A dummy variable equal to } 1 \text { if the student, } \\
\text { when asked "In the last two full weeks of } \\
\text { school, how many times did you skip a whole } \\
\text { school day?" ticked one of the following } \\
\text { answers: "one or two times", "three or four } \\
\text { times", "five or more times"; equal to } 0 \text { if s/he } \\
\text { ticked the answer "none". This variable is } \\
\text { present only in the } 2012 \text { PISA wave. }\end{array}$ & $\begin{array}{l}\text { Calculated using variable } \\
\text { ST09, present only in wave } \\
\text { 2012. }\end{array}$ \\
\hline \multicolumn{3}{|c|}{ Individual controls } \\
\hline Name of the variable & Description & Source \\
\hline Male & A variable equal to one if the student is a boy & $\begin{array}{l}\text { Calculated using variable } \\
\text { ST03Q01 in wave } 2003 \text { and } \\
\text { variable ST04Q01 in wave } \\
2006,2009,2012 .\end{array}$ \\
\hline Age & Age expressed in years. & $\begin{array}{l}\text { Corresponds to the variable } \\
\text { AGE }\end{array}$ \\
\hline Grade & School grade & $\begin{array}{l}\text { Corresponds to the variable } \\
\text { ST01Q01 }\end{array}$ \\
\hline Parents' education & $\begin{array}{l}\text { The variable takes values which correspond to } \\
\text { the following education levels: none; primary } \\
\text { education (ISCED 1); lower secondary } \\
\text { education (ISCED 2); upper secondary } \\
\text { education (ISCED 3B, C); post-secondary non- } \\
\text { tertiary education (ISCED 3A, 4); first stage of } \\
\text { tertiary education (ISCED 5B); second stage of } \\
\text { tertiary education (ISCED 5A, 6). In all the } \\
\text { regressions which control for this set of }\end{array}$ & $\begin{array}{l}\text { Constructed using the variable } \\
\text { HISCED }\end{array}$ \\
\hline
\end{tabular}




\begin{tabular}{|l|l|l|}
\hline & variables "none" is the omitted category. & \\
\hline Wealth & $\begin{array}{l}\text { Wealth is an index of family wealth possessions } \\
\text { built by OECD - PISA based on the student's } \\
\text { responses to several questions asking whether } \\
\text { there are specific items in the student's home. } \\
\text { Such items vary across waves, and some of } \\
\text { them are specific of the country where the test } \\
\text { is administered. This variable is present in the } \\
\text { 2006, 2009, and 2012 PISA waves. For details } \\
\text { see: https://www.oecd.org/pisa/. }\end{array}$ & \\
\hline
\end{tabular}




\section{A.3. Additional Tables}

Table A1

List of countries, first generation immigrants, unrestricted and restricted sample

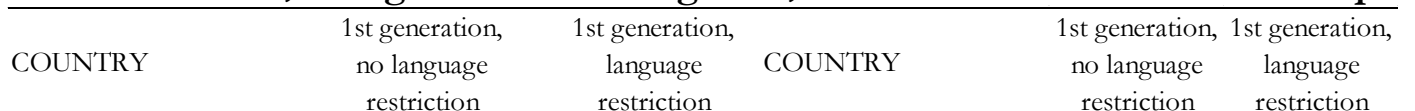

\begin{tabular}{|c|c|c|c|c|c|}
\hline Albania & 388 & 339 & Korea, Republic of & 639 & 388 \\
\hline Argentina & 3,754 & 3,631 & Lithuania & 91 & 81 \\
\hline Australia & 172 & 151 & Malaysia & 71 & 52 \\
\hline Austria & 70 & & Mexico & 15,750 & 15,133 \\
\hline Bangladesh & 342 & 271 & Morocco & 132 & 117 \\
\hline Belgium & 115 & 33 & Nepal & 40 & \\
\hline Bosnia and Herzegovina & 369 & 327 & Netherlands & 154 & 66 \\
\hline Brazil & 3,028 & 2,511 & New Zealand & 45 & 34 \\
\hline Bulgaria & 182 & 114 & Nigeria & 204 & 179 \\
\hline Canada & 2,312 & 1,782 & Norway & 59 & \\
\hline Chile & 786 & 721 & Pakistan & 495 & 477 \\
\hline China & 1,421 & 492 & Peru & 3,368 & 3,197 \\
\hline Colombia & 10,387 & 9,856 & Philippines & 1,697 & 1,603 \\
\hline Croatia & 71 & 55 & Poland & 188 & 134 \\
\hline Czech Republic & 35 & & Portugal & 99 & 47 \\
\hline Denmark & 40 & & Puerto Rico & 7,640 & 7,610 \\
\hline Dominican Republic & 2,342 & 2,329 & Romania & 287 & 154 \\
\hline Egypt & 246 & 190 & Russia & 1,250 & 469 \\
\hline El Salvador & 1,017 & 960 & Saudi Arabia & 302 & 69 \\
\hline Estonia & 30 & & Singapore & 69 & 53 \\
\hline Finland & 69 & 49 & South Africa & 288 & 254 \\
\hline France & 503 & 381 & Spain & 687 & 482 \\
\hline Germany & 2,657 & 512 & Sri Lanka & 38 & 35 \\
\hline Ghana & 52 & 46 & Sweden & 161 & 88 \\
\hline Greece & 220 & 72 & Switzerland & 86 & 30 \\
\hline Hong Kong & 48 & 38 & Taiwan & 75 & 47 \\
\hline Hungary & 141 & 85 & Tanzania, United Rep. of & 37 & \\
\hline Iceland & 77 & & Thailand & 240 & 144 \\
\hline India & 1,380 & 1,322 & Trinidad and Tobago & 513 & 508 \\
\hline Indonesia & 69 & 35 & Turkey & 196 & 114 \\
\hline Iran & 111 & 76 & Ukraine & 612 & 321 \\
\hline Iraq & 56 & 51 & United Kingdom & 2,366 & 2,103 \\
\hline Ireland & 76 & 67 & Uruguay & 1,120 & 1,084 \\
\hline Israel & 514 & 481 & Venezuela & 6,453 & 6,071 \\
\hline Italy & 656 & 178 & Vietnam & 773 & 659 \\
\hline Japan & 1,562 & 223 & Zimbabwe & 44 & 39 \\
\hline Jordan & 144 & 121 & Non-disclosed countries & 275 & 318 \\
\hline & & & Total & 81,986 & 69,659 \\
\hline
\end{tabular}

Notes. The table reports the number of observations by country of origin for both the unrestricted and restricted definition of first generation immigrants. The unit of observation is a student born between 1992 and 2002 and observed during the academic years 2002-2012. To identify unrestricted first generation immigrants we use only the information on the country of origin of the student. We also use a restricted definition of first generation immigrant when we restrict our analysis to those students who speak at home one of the languages spoken in their country of origin (we eliminate first generation immigrants who do not speak at home one the languages of their country of origin). The total in column 1 refers to the sample used to run the regression shown in Table 2, column (2). The total in column 2 refers to the sample used to run the regression shown in Table 2, column (5). For confidentiality reasons with the FLDOE, we cannot report the number of observations for groups whose size is smaller than 30. We refer to the sum of all of them, as Non-disclosed countries. See the text of this Appendix for details. 


\section{Table A2}

\section{List of languages, second generation immigrants, restricted and extended definition}

\begin{tabular}{|c|c|c|c|c|c|}
\hline $\begin{array}{c}\text { LANGUAGE (or } \\
\text { MATERNAL COUNTRY } \\
\text { OF BIRTH) }\end{array}$ & 2nd generation & $\begin{array}{l}\text { 2nd generation, } \\
\text { extended } \\
\text { definition }\end{array}$ & $\begin{array}{c}\text { LANGUAGE (or } \\
\text { MATERNAL COUNTRY } \\
\text { OF BIRTH) }\end{array}$ & 2nd generation & $\begin{array}{l}\text { 2nd generation, } \\
\text { extended definition }\end{array}$ \\
\hline Afrikaans & & 59 & Korean & 428 & 784 \\
\hline Akan & & 43 & Lao & 304 & 497 \\
\hline Albanian & 208 & 426 & Lithuanian & & 57 \\
\hline Amharic & 50 & 79 & Malay & 88 & 152 \\
\hline Arabic & 1,878 & 3,205 & Malayalam & 127 & 265 \\
\hline Armenian & 36 & 68 & Marathi & & 49 \\
\hline Bengali & 412 & 624 & Mexico (country) & 34,556 & 34,556 \\
\hline Bulgarian & 43 & 70 & Nepali & & 50 \\
\hline Chinese & 1,830 & 3,153 & Norwegian & & 52 \\
\hline Croatian & 50 & 83 & Panjabi & 41 & 72 \\
\hline Czech & 78 & 116 & Persian, Iranian & 232 & 372 \\
\hline Canada (country) & 3,769 & 3,769 & Polish & 349 & 690 \\
\hline Danish & & 45 & Portuguese & 2,294 & 3,965 \\
\hline Dutch & 143 & 224 & Puerto Rico (country) & 13,391 & 13,391 \\
\hline Estonian, Standard & 69 & 105 & Romanian & 191 & 304 \\
\hline Finnish & 46 & 96 & Russian & 528 & 1,134 \\
\hline French & 1,668 & 2,858 & Serbian & 314 & 507 \\
\hline German & 369 & 752 & Slovak & 37 & 63 \\
\hline Greek & 180 & 658 & Spanish & 65,294 & 187,672 \\
\hline Gujarati & 401 & 801 & Swahili & & 30 \\
\hline Haitian & 24,527 & 30,914 & Swedish & 97 & 154 \\
\hline Hausa & 57 & 77 & Tagalog & 928 & 1,714 \\
\hline Hebrew & 302 & 643 & Tamil & 91 & 189 \\
\hline Hindi & 368 & 676 & Telugu & 163 & 331 \\
\hline Hmong & & 131 & Thai & 202 & 303 \\
\hline Hungarian & 118 & 208 & Turkish & 122 & 236 \\
\hline Italian & 210 & 684 & Ukrainian & 44 & 114 \\
\hline Japanese & 178 & 340 & Urdu & 854 & 1,339 \\
\hline Kanjobal & & 90 & Vietnamese & 2,500 & 4,442 \\
\hline Kannada & & 46 & Yoruba & 62 & 116 \\
\hline \multirow[t]{2}{*}{ Khmer } & 213 & 461 & Not-disclosed languages & 323 & 278 \\
\hline & & & & 160,763 & 305,382 \\
\hline
\end{tabular}

Notes. The table reports the number of observations by language spoken at home. The unit of observation is a student born between 1992 and 2002 and observed during the academic years 2002-2012. To identify "2nd generation" immigrants we include all children born in Florida whose mothers were born abroad. If the country of origin of the mothers is indicated in the birth certificate (Canada, Mexico, Puerto Rico) we attribute the corresponding country to the student. If the birth certificate indicates only that the mother was born abroad, we use the language spoken at home to attribute the Long Term Orientation variable. To identify " 2 nd generation, extended definition" immigrants we consider in addition to the " 2 nd generation" immigrants every other student who speaks a language different from English at home. We match the language with the LTO variable according to the procedure explained in this Appendix. For confidentiality reasons with the FLDOE, we cannot report the number of observations for groups whose size is smaller than 30 . We refer to the sum of all of them, as Non-disclosed languages. 
Table A3

Descriptive statistics of students attending public and private schools in Florida, Natives, First and Second Generation Immigrants

\begin{tabular}{|c|c|c|c|c|c|c|}
\hline \multicolumn{7}{|c|}{ Panel A: Enrollment in Public School } \\
\hline & \multicolumn{2}{|c|}{ Natives } & \multicolumn{2}{|c|}{ 1st generation } & \multicolumn{2}{|c|}{ 2nd generation } \\
\hline & Obs. & Mean & Obs. & Mean & Obs. & Mean \\
\hline \multicolumn{7}{|c|}{ Census $2000(5 \%)$} \\
\hline Kindergarten & 6,415 & $82.29 \%$ & 646 & $84.83 \%$ & 2,582 & $81.14 \%$ \\
\hline Grade 1 to 4 & 26,500 & $86.69 \%$ & 3,279 & $93.44 \%$ & 9,438 & $86.76 \%$ \\
\hline Grade 5 to 8 & 26,581 & $87.86 \%$ & 4,477 & $93.52 \%$ & 8,244 & $87.58 \%$ \\
\hline Grade 9 to 12 & 21,813 & $90.58 \%$ & 5,289 & $93.67 \%$ & 6,576 & $87.61 \%$ \\
\hline Overall sample & 81,309 & $87.77 \%$ & 13,691 & $93.15 \%$ & 26,840 & $86.68 \%$ \\
\hline
\end{tabular}

Census $2010(1 \%)$

\begin{tabular}{|c|c|c|c|c|c|c|}
\hline Kindergarten & 1,147 & $82.65 \%$ & 91 & $74.73 \%$ & 632 & $83.23 \%$ \\
\hline Grade 1 to 4 & 4,556 & $85.45 \%$ & 557 & $89.77 \%$ & 2,301 & $88.57 \%$ \\
\hline Grade 5 to 8 & 5,047 & $85.56 \%$ & 855 & $90.64 \%$ & 2,036 & $87.18 \%$ \\
\hline Grade 9 to 12 & 4,726 & $87.85 \%$ & 1,114 & $92.91 \%$ & 1,861 & $88.07 \%$ \\
\hline Overall sample & 15,476 & $86.01 \%$ & 2,617 & $90.87 \%$ & 6,830 & $87.53 \%$ \\
\hline \multicolumn{7}{|c|}{ Panel B: Family Income (USD) } \\
\hline & \multicolumn{2}{|c|}{ Natives } & \multicolumn{2}{|c|}{ 1st generation } & \multicolumn{2}{|c|}{ 2nd generation } \\
\hline & Obs. & Mean & Obs. & Mean & Obs. & Mean \\
\hline \multicolumn{7}{|c|}{ Census $2000(5 \%)$} \\
\hline Public school & 71,364 & 55,838 & 12,648 & 43,526 & 23,264 & 52,842 \\
\hline Private school & 9,945 & 102,409 & 928 & 86,163 & 3,576 & 106,669 \\
\hline Overall sample & 81,309 & 61,534 & 13,576 & 46,441 & 26,840 & 60,014 \\
\hline \multicolumn{7}{|c|}{ Census $2010(1 \%)$} \\
\hline Public school & 13,311 & 71,906 & 2,372 & 54,343 & 5,978 & 65,630 \\
\hline Private school & 2,165 & 123,921 & 238 & 115,190 & 852 & 136,119 \\
\hline Overall sample & 15,476 & 79,183 & 2,610 & 59,892 & 6,830 & 74,423 \\
\hline \multicolumn{7}{|c|}{$\begin{array}{l}\text { Notes. The table reports the fraction of students by grade and family } \\
\text { income enrolled in public and private schools in Florida. The data are } \\
\text { based on Census } 2000 \text { and } 2010 \text { and report the statistics for natives, first } \\
\text { generation immigrants and second generation immigrants. "2nd } \\
\text { generation" is identified as having at least the mother or the father born } \\
\text { abroad. }\end{array}$} \\
\hline
\end{tabular}


Table A4

Long-Term Orientation and maternal characteristics, extended second generation

\begin{tabular}{|c|c|c|c|c|c|c|c|c|}
\hline VARIABLES & $\begin{array}{c}\text { (1) } \\
\text { Math score, } \\
\text { 3rd grade }\end{array}$ & $\begin{array}{c}\text { (2) } \\
\text { Math score, } \\
\text { change 3rd to } 8 \text { th }\end{array}$ & $\begin{array}{c}\text { (3) } \\
\text { Reading score, } \\
\text { 3rd grade }\end{array}$ & $\begin{array}{c}\text { (4) } \\
\text { Reading score, } \\
\text { change } 3 \text { rd to } 8 \text { th }\end{array}$ & $\begin{array}{c}\text { (5) } \\
\text { Graduation }\end{array}$ & $\begin{array}{c}(6) \\
\% \text { Absent } \\
\text { Days } \\
\end{array}$ & $\begin{array}{c}(7) \\
\text { Disciplinary } \\
\text { Incident } \\
\end{array}$ & $\begin{array}{c}(8) \\
\text { Retention }\end{array}$ \\
\hline Long-Term Orientation & $\begin{array}{c}0.697 * * * \\
(0.124)\end{array}$ & $\begin{array}{c}0.449 * * * \\
(0.117)\end{array}$ & $\begin{array}{c}0.452 * * * \\
(0.071)\end{array}$ & $\begin{array}{c}0.377 * * * \\
(0.101)\end{array}$ & $\begin{array}{c}0.024 \\
(0.014)\end{array}$ & $\begin{array}{c}-0.020 * * \\
(0.008)\end{array}$ & $\begin{array}{c}-0.139 * * * \\
(0.036)\end{array}$ & $\begin{array}{c}-0.016 * * * \\
(0.003)\end{array}$ \\
\hline Mother high school graduate & $\begin{array}{c}0.083^{* * *} \\
(0.020)\end{array}$ & $\begin{array}{c}0.022^{* *} \\
(0.010)\end{array}$ & $\begin{array}{c}0.089 \text { *** } \\
(0.019)\end{array}$ & $\begin{array}{l}0.032^{*} \\
(0.018)\end{array}$ & $\begin{array}{c}0.013 \\
(0.008)\end{array}$ & $\begin{array}{l}-0.001 \\
(0.001)\end{array}$ & $\begin{array}{c}-0.021 \text { ** } \\
(0.009)\end{array}$ & $\begin{array}{c}-0.009 * * * \\
(0.002)\end{array}$ \\
\hline Mother attended some college & $\begin{array}{c}0.170 * * * \\
(0.020)\end{array}$ & $\begin{array}{c}0.052^{* * *} \\
(0.015)\end{array}$ & $\begin{array}{c}0.177 * * * \\
(0.014)\end{array}$ & $\begin{array}{c}0.067 * * * \\
(0.015)\end{array}$ & $\begin{array}{c}0.018 \\
(0.018)\end{array}$ & $\begin{array}{l}-0.001 \\
(0.002)\end{array}$ & $\begin{array}{c}-0.028^{* * *} \\
(0.009)\end{array}$ & $\begin{array}{c}-0.013^{* * *} \\
(0.002)\end{array}$ \\
\hline Mother $4 \mathrm{yr}$ college graduate & $\begin{array}{c}0.337 \text { *** } \\
(0.015)\end{array}$ & $\begin{array}{c}0.153^{* * *} \\
(0.008)\end{array}$ & $\begin{array}{c}0.317^{* * *} \\
(0.011)\end{array}$ & $\begin{array}{c}0.175^{* * *} \\
(0.016)\end{array}$ & $\begin{array}{c}0.049 * * * \\
(0.010)\end{array}$ & $\begin{array}{c}-0.006^{* *} \\
(0.002)\end{array}$ & $\begin{array}{c}-0.051^{* * * *} \\
(0.010)\end{array}$ & $\begin{array}{c}-0.016^{* * *} \\
(0.002)\end{array}$ \\
\hline Mother teen pregnancy & $\begin{array}{c}-0.070^{* * *} \\
(0.024)\end{array}$ & $\begin{array}{c}0.003 \\
(0.036)\end{array}$ & $\begin{array}{l}-0.019 \\
(0.027)\end{array}$ & $\begin{array}{l}-0.053 \\
(0.049)\end{array}$ & $\begin{array}{c}0.042 \\
(0.031)\end{array}$ & $\begin{array}{c}0.012 * * * \\
(0.002)\end{array}$ & $\begin{array}{c}0.049 * * * \\
(0.010)\end{array}$ & $\begin{array}{c}0.005 \\
(0.003)\end{array}$ \\
\hline Mother married at time of birth & $\begin{array}{c}0.102^{* * *} \\
(0.007)\end{array}$ & $\begin{array}{c}0.056 * * * \\
(0.005)\end{array}$ & $\begin{array}{c}0.084 * * * \\
(0.005)\end{array}$ & $\begin{array}{c}0.048 * * * \\
(0.008)\end{array}$ & $\begin{array}{c}0.037 * * * \\
(0.008)\end{array}$ & $\begin{array}{c}-0.007 * * * \\
(0.000)\end{array}$ & $\begin{array}{c}-0.058^{* * *} \\
(0.005)\end{array}$ & $\begin{array}{c}-0.008 * * * \\
(0.001)\end{array}$ \\
\hline Number of older siblings & $\begin{array}{c}-0.028 * * * \\
(0.004)\end{array}$ & $\begin{array}{c}-0.012^{* * *} \\
(0.003)\end{array}$ & $\begin{array}{c}-0.039 * * * \\
(0.006)\end{array}$ & $\begin{array}{l}-0.008 \\
(0.005)\end{array}$ & $\begin{array}{c}-0.005^{* * *} \\
(0.001)\end{array}$ & $\begin{array}{c}0.003^{* * *} \\
(0.001)\end{array}$ & $\begin{array}{c}0.021 * * * \\
(0.001)\end{array}$ & $\begin{array}{c}0.003^{* * *} \\
(0.001)\end{array}$ \\
\hline Median income in zipcode of birth $(100,000$ of $\$)$ & $\begin{array}{c}0.173^{* * * *} \\
(0.026)\end{array}$ & $\begin{array}{c}0.002 \\
(0.032)\end{array}$ & $\begin{array}{c}0.143^{* * *} \\
(0.013)\end{array}$ & $\begin{array}{c}0.044^{* *} \\
(0.018)\end{array}$ & $\begin{array}{c}0.064 * * * \\
(0.019)\end{array}$ & $\begin{array}{c}0.004 \\
(0.003)\end{array}$ & $\begin{array}{c}-0.039^{* *} \\
(0.017)\end{array}$ & $\begin{array}{c}-0.011^{\text {**** }} \\
(0.002)\end{array}$ \\
\hline Male & $\begin{array}{c}0.128 * * * \\
(0.020)\end{array}$ & $\begin{array}{c}-0.047^{* * *} \\
(0.008)\end{array}$ & $\begin{array}{c}-0.067^{* * *} \\
(0.017)\end{array}$ & $\begin{array}{c}-0.067^{* * *} \\
(0.008)\end{array}$ & $\begin{array}{c}-0.042^{* * *} \\
(0.007)\end{array}$ & $\begin{array}{c}0.000 \\
(0.000)\end{array}$ & $\begin{array}{c}0.096^{* * *} \\
(0.005)\end{array}$ & $\begin{array}{c}0.013^{* * *} \\
(0.002)\end{array}$ \\
\hline Age in months & $\begin{array}{c}-0.010^{* * *} \\
(0.001)\end{array}$ & $\begin{array}{c}-0.016^{* * *} \\
(0.001)\end{array}$ & $\begin{array}{c}-0.012^{* * *} \\
(0.001)\end{array}$ & $\begin{array}{c}-0.011 * * * \\
(0.001)\end{array}$ & $\begin{array}{c}0.001 \\
(0.002)\end{array}$ & $\begin{array}{c}0.001^{* * *} \\
(0.000)\end{array}$ & $\begin{array}{c}0.007 * * * \\
(0.000)\end{array}$ & $\begin{array}{c}-0.001^{* * *} \\
(0.000)\end{array}$ \\
\hline Free or Reduced Priced Lunch & $\begin{array}{c}-0.154^{* * *} * \\
(0.008)\end{array}$ & $\begin{array}{c}-0.035^{* * *} \\
(0.008)\end{array}$ & $\begin{array}{c}-0.163^{* * * *} \\
(0.009)\end{array}$ & $\begin{array}{c}-0.064 * * * \\
(0.008)\end{array}$ & $\begin{array}{c}-0.018^{* *} \\
(0.008)\end{array}$ & $\begin{array}{c}0.000 \\
(0.002)\end{array}$ & $\begin{array}{c}0.037 * * * \\
(0.003)\end{array}$ & $\begin{array}{c}0.006^{* * *} \\
(0.000)\end{array}$ \\
\hline Special education & $\begin{array}{c}-0.658^{* * *} \\
(0.022)\end{array}$ & $\begin{array}{c}-0.233^{* * *} \\
(0.006)\end{array}$ & $\begin{array}{c}-0.753^{* * *} \\
(0.024)\end{array}$ & $\begin{array}{c}-0.187^{* * *} \\
(0.008)\end{array}$ & $\begin{array}{c}-0.173^{* * *} \\
(0.012)\end{array}$ & $\begin{array}{c}0.006^{* * *} \\
(0.000)\end{array}$ & $\begin{array}{c}0.017 * * * \\
(0.002)\end{array}$ & $\begin{array}{c}0.037^{* * *} \\
(0.001)\end{array}$ \\
\hline Enrolled in Limited English proficiency program & $\begin{array}{c}-0.612 * * * \\
(0.005)\end{array}$ & & $\begin{array}{c}-0.689 * * * \\
(0.011)\end{array}$ & & $\begin{array}{c}-0.204^{* *} \\
(0.080)\end{array}$ & $\begin{array}{c}0.002 * * \\
(0.001)\end{array}$ & $\begin{array}{c}0.046^{* * *} \\
(0.005)\end{array}$ & $\begin{array}{c}0.070^{* * *} \\
(0.003)\end{array}$ \\
\hline Enrolled in Limited English proficiency program in grade 3 & & $\begin{array}{l}-0.005 \\
(0.015)\end{array}$ & & $\begin{array}{c}-0.114^{* * *} \\
(0.012)\end{array}$ & & & & \\
\hline Math score in grade 3 & & $\begin{array}{c}-0.368^{* * *} \\
(0.008)\end{array}$ & & & & & & \\
\hline Reading score in grade 3 & & & & $\begin{array}{c}-0.417^{* * *} \\
(0.006)\end{array}$ & & & & \\
\hline Observations & 184,331 & 62,005 & 184,309 & 61,668 & 6,623 & 960,054 & 425,110 & 762,581 \\
\hline R-squared & 0.368 & 0.334 & 0.379 & 0.319 & 0.324 & 0.182 & 0.150 & 0.121 \\
\hline Year*school FE & YES & YES & YES & YES & YES & YES & YES & YES \\
\hline Grade FE & - & - & - & - & - & YES & YES & YES \\
\hline Dependent Variable (mean) & 0.000 & 0.000 & 0.000 & 0.000 & 0.874 & 0.045 & 0.208 & 0.042 \\
\hline Dependent Variable (sd) & 1.000 & 0.778 & 1.000 & 0.809 & 0.332 & 0.057 & 0.406 & 0.200 \\
\hline Long-Term Orientation (mean) & 0.207 & 0.209 & 0.207 & 0.210 & 0.214 & 0.206 & 0.206 & 0.206 \\
\hline Long-Term Orientation (sd) & 0.143 & 0.149 & 0.143 & 0.149 & 0.158 & 0.144 & 0.146 & 0.144 \\
\hline Long-Term Orientation (beta) & 0.100 & 0.086 & 0.065 & 0.070 & 0.011 & -0.049 & -0.050 & -0.011 \\
\hline N_clust & 90 & 79 & 90 & 79 & 58 & 90 & 82 & 90 \\
\hline
\end{tabular}

Notes. The table replicates the results in Table 6 for the following dependent variables: students' Florida Comprehensive Assessment Test reading score in grade 3 (standardized with mean 0 and variance 1), the change in reading score from grade 3 to grade 8 , high school graduation (a dummy for whether the student received a standard diploma within four years after entering the $9^{\text {th }}$ grade for the first time), absence rates (the percentage of days in which the student is absent during the academic year) and retention (an indicator for whether the student repeats the same grade at least once) measured in grades 3-12, and disciplinary incidents (a dummy for whether the student was involved in a disciplinary incident defined as serious offences often leading to suspension) measured in grades 6-12.. The table reports OLS estimates, with standard errors clustered at the language/country level. The unit of observation is a student born between 1992 and 2002 and observed during the academic years 2002-2012. The sample includes the extended version of second generation immigrants defined using the information on the country of origin of the mother when available (Canada, Mexico, and Puerto Rico), or the language spoken at home for the remaining students for which the country of origin of the mother is not available. See details in the text and this Appendix for how the matching between languages and countries has been implemented. Individual controls are: age in months, a male dummy, an indicator variable for free or reduced free lunch eligibility, a dummy indicating if the student is enrolled in a limited English proficiency program and indicator for special education needs. Maternal controls include education dummies (high school, some college and college graduate; the excluded group is college drop-out), whether the mother was younger than 16 when she gave birth, the mother's marital status at the time of birth, the number of older siblings, and the median income in the zip code of the place of residence at the time of birth (measured in 1999). The "Long Term Orientation" variable is based on Hofstede (2010) and is measured on a 0-1 scale. We describe in details all the variables in this Appendix. ***, **, and * indicate significance at the $1 \%, 5 \%$, and $10 \%$ levels. 
Table A5

Educational outcomes and long term orientation, robustness to country controls, first generation immigrants

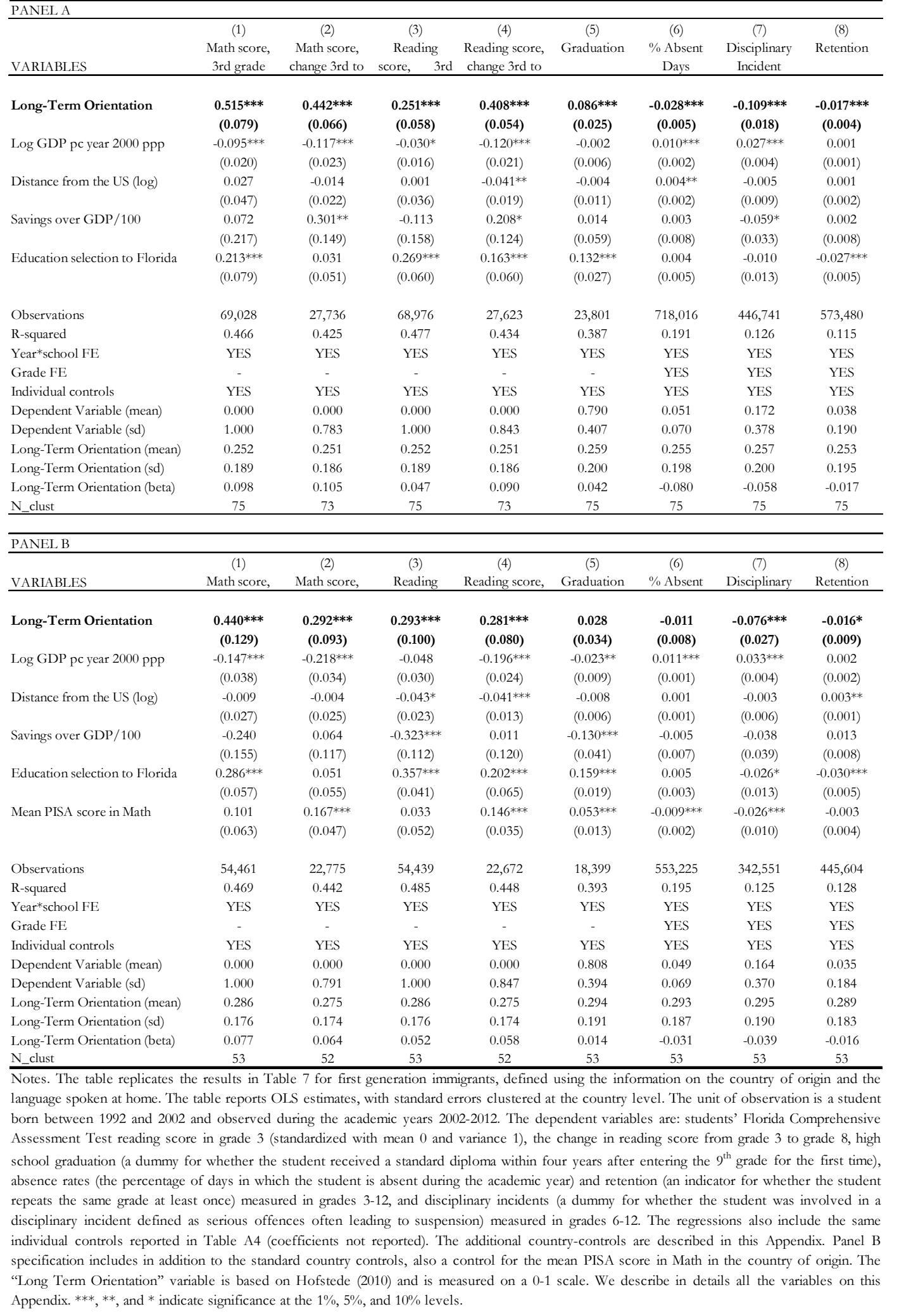


Table A6

Educational outcomes and long term orientation, robustness to country controls, second generation immigrants, extended definition

\begin{tabular}{|c|c|c|c|c|c|c|c|c|}
\hline VARIABLES & $\begin{array}{c}\text { (1) } \\
\text { Math score, } \\
\text { 3rd grade }\end{array}$ & $\begin{array}{c}\text { (2) } \\
\text { Math score, } \\
\text { change 3rd to }\end{array}$ & $\begin{array}{c}\text { (3) } \\
\text { Reading } \\
\text { score, 3rd }\end{array}$ & $\begin{array}{l}\text { (4) } \\
\text { Reading score, } \\
\text { change } 3 r d \text { to }\end{array}$ & $\begin{array}{c}\text { (5) } \\
\text { Graduation }\end{array}$ & $\begin{array}{c}\text { (6) } \\
\% \text { Absent } \\
\text { Days }\end{array}$ & $\begin{array}{c}(7) \\
\text { Disciplinary } \\
\text { Incident } \\
\end{array}$ & $\begin{array}{c}(8) \\
\text { Retention }\end{array}$ \\
\hline Long-Term Orientation & $\begin{array}{c}0.688 * * * \\
(0.113)\end{array}$ & $\begin{array}{c}0.454 * * * \\
(0.069)\end{array}$ & $\begin{array}{c}0.502 * * * \\
(0.089)\end{array}$ & $\begin{array}{c}0.405 * * * \\
(0.063)\end{array}$ & $\begin{array}{c}0.136 * * * \\
(0.038)\end{array}$ & $\begin{array}{c}-0.042^{* *} \\
(0.016)\end{array}$ & $\begin{array}{c}-0.119 * * \\
(0.048)\end{array}$ & $\begin{array}{c}-0.022 * * * \\
(0.006)\end{array}$ \\
\hline Log GDP pc year 2000 ppp & $\begin{array}{c}-0.100^{* * *} \\
(0.025)\end{array}$ & $\begin{array}{c}-0.111^{* * * *} \\
(0.016)\end{array}$ & $\begin{array}{l}-0.022 \\
(0.019)\end{array}$ & $\begin{array}{c}-0.095^{* * *} \\
(0.013)\end{array}$ & $\begin{array}{l}-0.006 \\
(0.010)\end{array}$ & $\begin{array}{c}0.012^{* * *} \\
(0.003)\end{array}$ & $\begin{array}{c}0.027^{* * *} \\
(0.009)\end{array}$ & $\begin{array}{c}0.001 \\
(0.001)\end{array}$ \\
\hline Distance from the US (log) & $\begin{array}{l}-0.003 \\
(0.061)\end{array}$ & $\begin{array}{l}-0.032^{*} \\
(0.017)\end{array}$ & $\begin{array}{l}-0.025 \\
(0.048)\end{array}$ & $\begin{array}{l}-0.021 \\
(0.015)\end{array}$ & $\begin{array}{l}-0.012 \\
(0.010)\end{array}$ & $\begin{array}{l}0.011^{*} \\
(0.006)\end{array}$ & $\begin{array}{l}-0.026 \\
(0.025)\end{array}$ & $\begin{array}{l}-0.001 \\
(0.003)\end{array}$ \\
\hline Savings over GDP/100 & $\begin{array}{c}1.527^{* * *} \\
(0.324)\end{array}$ & $\begin{array}{c}0.938^{* * *} \\
(0.240)\end{array}$ & $\begin{array}{c}0.822 * * * \\
(0.248)\end{array}$ & $\begin{array}{c}0.636^{* * *} \\
(0.212)\end{array}$ & $\begin{array}{c}0.031 \\
(0.135)\end{array}$ & $\begin{array}{c}0.045 \\
(0.061)\end{array}$ & $\begin{array}{c}-0.435^{* * * *} \\
(0.163)\end{array}$ & $\begin{array}{l}-0.022 \\
(0.017)\end{array}$ \\
\hline Education selection to Florida & $\begin{array}{c}0.066 \\
(0.131)\end{array}$ & $\begin{array}{c}0.032 \\
(0.049)\end{array}$ & $\begin{array}{c}0.182^{* *} \\
(0.080)\end{array}$ & $\begin{array}{c}0.047 \\
(0.036)\end{array}$ & $\begin{array}{l}0.050^{* *} \\
(0.023)\end{array}$ & $\begin{array}{c}0.007 \\
(0.011)\end{array}$ & $\begin{array}{c}0.045 \\
(0.062)\end{array}$ & $\begin{array}{l}-0.009 * \\
(0.005)\end{array}$ \\
\hline Observations & 295,119 & 103,388 & 295,103 & 102,892 & 55,274 & $2,095,753$ & $1,126,026$ & $1,714,203$ \\
\hline R-squared & 0.345 & 0.315 & 0.354 & 0.296 & 0.344 & 0.210 & 0.132 & 0.095 \\
\hline Year*school FE & YES & YES & YES & YES & YES & YES & YES & YES \\
\hline Grade FE & - & - & - & - & - & YES & YES & YES \\
\hline Individual controls & YES & YES & YES & YES & YES & YES & YES & YES \\
\hline Dependent Variable (mean) & 0.000 & 0.000 & 0.000 & 0.000 & 0.766 & 0.053 & 0.229 & 0.047 \\
\hline Dependent Variable (sd) & 1.000 & 0.777 & 1.000 & 0.815 & 0.423 & 0.071 & 0.420 & 0.211 \\
\hline Long-Term Orientation (mean) & 0.199 & 0.201 & 0.199 & 0.201 & 0.198 & 0.197 & 0.196 & 0.197 \\
\hline Long-Term Orientation (sd) & 0.128 & 0.133 & 0.128 & 0.133 & 0.129 & 0.127 & 0.126 & 0.127 \\
\hline Long-Term Orientation (beta) & 0.088 & 0.078 & 0.064 & 0.066 & 0.041 & -0.075 & -0.036 & -0.013 \\
\hline N_clust & 71 & 66 & 71 & 66 & 65 & 73 & 70 & 72 \\
\hline \multicolumn{9}{|l|}{ PANEL B } \\
\hline VARIABLES & $\begin{array}{c}\text { (1) } \\
\text { Math score, } \\
\text { 3rd grade }\end{array}$ & $\begin{array}{c}\text { (2) } \\
\text { Math score, } \\
\text { change 3rd to } \\
\text { 8th }\end{array}$ & $\begin{array}{c}\text { (3) } \\
\text { Reading } \\
\text { score, 3rd } \\
\text { grade }\end{array}$ & $\begin{array}{c}\text { (4) } \\
\text { Reading score, } \\
\text { change 3rd to } \\
\text { 8th }\end{array}$ & $\begin{array}{c}\text { (5) } \\
\text { Graduation }\end{array}$ & $\begin{array}{c}\text { (6) } \\
\% \text { Absent } \\
\text { Days }\end{array}$ & $\begin{array}{c}(7) \\
\text { Disciplinary } \\
\text { Incident }\end{array}$ & $\begin{array}{c}\text { (8) } \\
\text { Retention }\end{array}$ \\
\hline Long-Term Orientation & $\begin{array}{c}0.383 * * \\
(0.176)\end{array}$ & $\begin{array}{c}0.376 * * \\
(0.147)\end{array}$ & $\begin{array}{c}0.290 * * \\
(0.139)\end{array}$ & $\begin{array}{c}0.469 * * * \\
(0.119)\end{array}$ & $\begin{array}{c}0.072 \\
(0.055)\end{array}$ & $\begin{array}{c}-0.015^{* *} \\
(0.007)\end{array}$ & $\begin{array}{l}-0.020 \\
(0.026)\end{array}$ & $\begin{array}{l}-0.005 \\
(0.005)\end{array}$ \\
\hline Log GDP pc year 2000 ppp & $\begin{array}{c}-0.085^{* * *} \\
(0.030)\end{array}$ & $\begin{array}{c}-0.131 * * * \\
(0.018)\end{array}$ & $\begin{array}{l}-0.004 \\
(0.018)\end{array}$ & $\begin{array}{c}-0.115^{* * *} \\
(0.021)\end{array}$ & $\begin{array}{c}0.001 \\
(0.010)\end{array}$ & $\begin{array}{c}0.009^{* * *} \\
(0.001)\end{array}$ & $\begin{array}{c}0.023^{* * *} \\
(0.004)\end{array}$ & $\begin{array}{c}0.000 \\
(0.001)\end{array}$ \\
\hline Distance from the US (log) & $\begin{array}{l}-0.054 \\
(0.033)\end{array}$ & $\begin{array}{l}-0.025 \\
(0.016)\end{array}$ & $\begin{array}{c}-0.067^{* * * *} \\
(0.023)\end{array}$ & $\begin{array}{l}-0.021 \\
(0.021)\end{array}$ & $\begin{array}{l}-0.001 \\
(0.010)\end{array}$ & $\begin{array}{c}0.001 \\
(0.001)\end{array}$ & $\begin{array}{l}-0.004 \\
(0.005)\end{array}$ & $\begin{array}{l}-0.000 \\
(0.001)\end{array}$ \\
\hline Savings over GDP/100 & $\begin{array}{c}0.881 \text { *** } \\
(0.423)\end{array}$ & $\begin{array}{c}0.407 \\
(0.313)\end{array}$ & $\begin{array}{c}0.338 \\
(0.341)\end{array}$ & $\begin{array}{l}-0.165 \\
(0.312)\end{array}$ & $\begin{array}{c}0.114 \\
(0.125)\end{array}$ & $\begin{array}{c}-0.084 * * * \\
(0.015)\end{array}$ & $\begin{array}{c}-0.382^{* * *} \\
(0.071)\end{array}$ & $\begin{array}{l}-0.001 \\
(0.012)\end{array}$ \\
\hline Education selection to Florida & $\begin{array}{c}0.285^{* * *} \\
(0.057)\end{array}$ & $\begin{array}{l}-0.029 \\
(0.082)\end{array}$ & $\begin{array}{c}0.401 * * * \\
(0.043)\end{array}$ & $\begin{array}{l}-0.070 \\
(0.058)\end{array}$ & $\begin{array}{c}0.053^{* *} \\
(0.026)\end{array}$ & $\begin{array}{c}0.011^{* * *} \\
(0.002)\end{array}$ & $\begin{array}{c}-0.031 * * * \\
(0.010)\end{array}$ & $\begin{array}{c}-0.020^{* * *} \\
(0.003)\end{array}$ \\
\hline Mean PISA score in Math & $\begin{array}{c}0.076 \\
(0.060)\end{array}$ & $\begin{array}{c}0.024 \\
(0.040)\end{array}$ & $\begin{array}{c}0.062 \\
(0.040)\end{array}$ & $\begin{array}{l}-0.003 \\
(0.038)\end{array}$ & $\begin{array}{l}0.026^{*} \\
(0.014)\end{array}$ & $\begin{array}{l}-0.000 \\
(0.001)\end{array}$ & $\begin{array}{l}-0.012 \\
(0.007)\end{array}$ & $\begin{array}{c}-0.005^{* * *} \\
(0.001)\end{array}$ \\
\hline Observations & 53,916 & 17,438 & 53,911 & 17,420 & 7,620 & 329,514 & 164,259 & 267,566 \\
\hline R-squared & 0.488 & 0.485 & 0.513 & 0.473 & 0.431 & 0.248 & 0.166 & 0.166 \\
\hline Year*school FE & YES & YES & YES & YES & YES & YES & YES & YES \\
\hline Grade FE & - & - & - & - & - & YES & YES & YES \\
\hline Individual controls & YES & YES & YES & YES & YES & YES & YES & YES \\
\hline Dependent Variable (mean) & 0.000 & 0.000 & 0.000 & 0.000 & 0.800 & 0.045 & 0.185 & 0.042 \\
\hline Dependent Variable (sd) & 1.000 & 0.746 & 1.000 & 0.794 & 0.400 & 0.065 & 0.388 & 0.200 \\
\hline Long-Term Orientation (mean) & 0.331 & 0.344 & 0.331 & 0.344 & 0.369 & 0.344 & 0.353 & 0.345 \\
\hline Long-Term Orientation (sd) & 0.147 & 0.154 & 0.147 & 0.154 & 0.164 & 0.155 & 0.159 & 0.155 \\
\hline Long-Term Orientation (beta) & 0.056 & 0.078 & 0.043 & 0.091 & 0.030 & -0.036 & -0.008 & -0.004 \\
\hline N_clust & 42 & 41 & 42 & 41 & 38 & 43 & 41 & 42 \\
\hline
\end{tabular}

Notes. The table replicates the results in Table 7 for the extended definition of second generation immigrants (see this Appendix for details). The table reports OLS estimates, with standard errors clustered at the country level. The unit of observation is a student born between 1992 and 2002 and observed during the academic years 2002-2012. The dependent variables are: students' Florida Comprehensive Assessment Test reading score in grade 3 (standardized with mean 0 and variance 1), the change in reading score from grade 3 to grade 8 , high school graduation (a dummy for whether the student received a standard diploma within four years after entering the $9^{\text {th }}$ grade for the first time), absence rates (the percentage of days in which the student is absent during the academic year) and retention (an indicator for whether the student repeats the same grade at least once) measured in grades 3-12, and disciplinary incidents (a dummy for whether the student was involved in a disciplinary incident defined as serious offences often leading to suspension) measured in grades 6-12. The regressions also include the same individual controls reported in table A4 (coefficients not reported). The additional country-controls are described in this Appendix. The additional country-controls are described in this Appendix. Panel B specification includes in addition to the standard country controls, also a control for the mean PISA score in Math in the country of origin. The "Long Term Orientation" variable is based on Hofstede (2010) and is measured on a 0-1 scale. We describe in details all the variables on this Appendix. ***, **, and * indicate significance at the $1 \%, 5 \%$, and $10 \%$ levels. 
Table A7

Educational outcomes and long term orientation, robustness to country controls, second generation immigrants

\begin{tabular}{|c|c|c|c|c|c|c|c|c|}
\hline VARIABLES & $\begin{array}{c}\text { (1) } \\
\text { Math score, } \\
\text { 3rd grade } \\
\end{array}$ & $\begin{array}{c}\text { (2) } \\
\text { Math score, } \\
\text { change 3rd to 8th }\end{array}$ & $\begin{array}{c}\text { (3) } \\
\text { Reading score, } \\
\text { 3rd grade }\end{array}$ & $\begin{array}{c}\text { (4) } \\
\text { Reading score, } \\
\text { change 3rd to 8th }\end{array}$ & $\begin{array}{c}\text { (5) } \\
\text { Graduation }\end{array}$ & $\begin{array}{c}(6) \\
\% \text { Absent } \\
\text { Days } \\
\end{array}$ & $\begin{array}{c}(7) \\
\text { Disciplinary } \\
\text { Incident } \\
\end{array}$ & $\begin{array}{c}\text { (8) } \\
\text { Retention }\end{array}$ \\
\hline Long-Term Orientation & $\begin{array}{c}0.343 * * * \\
(0.106)\end{array}$ & $\begin{array}{c}0.403 * * * \\
(0.064)\end{array}$ & $\begin{array}{c}0.190^{* *} \\
(0.086)\end{array}$ & $\begin{array}{c}0.628 * * * \\
(0.063)\end{array}$ & $\begin{array}{c}0.127 * * * \\
(0.034)\end{array}$ & $\begin{array}{c}-0.052 * * * \\
(0.016)\end{array}$ & $\begin{array}{c}0.001 \\
(0.026)\end{array}$ & $\begin{array}{c}0.000 \\
(0.002)\end{array}$ \\
\hline Log GDP pc year 2000 ppp & $\begin{array}{c}-0.075^{* * *} \\
(0.028)\end{array}$ & $\begin{array}{c}-0.114^{* * *} \\
(0.015)\end{array}$ & $\begin{array}{c}0.007 \\
(0.025)\end{array}$ & $\begin{array}{c}-0.138^{* * *} \\
(0.020)\end{array}$ & $\begin{array}{c}-0.023^{* *} \\
(0.011)\end{array}$ & $\begin{array}{c}0.011^{* * * *} \\
(0.004)\end{array}$ & $\begin{array}{l}0.015^{*} \\
(0.008)\end{array}$ & $\begin{array}{l}-0.000 \\
(0.001)\end{array}$ \\
\hline Distance from the US (log) & $\begin{array}{c}0.161 * * * \\
(0.046)\end{array}$ & $\begin{array}{l}-0.001 \\
(0.025)\end{array}$ & $\begin{array}{c}0.126^{* * *} \\
(0.036)\end{array}$ & $\begin{array}{c}-0.085^{* * * *} \\
(0.031)\end{array}$ & $\begin{array}{c}0.013 \\
(0.012)\end{array}$ & $\begin{array}{l}0.016^{*} \\
(0.009)\end{array}$ & $\begin{array}{c}-0.085^{* * *} \\
(0.013)\end{array}$ & $\begin{array}{c}-0.013^{* * *} \\
(0.001)\end{array}$ \\
\hline Savings over GDP/100 & $\begin{array}{c}1.384^{* * *} \\
(0.299)\end{array}$ & $\begin{array}{c}0.735^{* * * *} \\
(0.184)\end{array}$ & $\begin{array}{c}0.552^{* *} \\
(0.230)\end{array}$ & $\begin{array}{l}0.333^{*} \\
(0.195)\end{array}$ & $\begin{array}{l}-0.126 \\
(0.104)\end{array}$ & $\begin{array}{c}0.029 \\
(0.042)\end{array}$ & $\begin{array}{c}-0.344^{* * * *} \\
(0.072)\end{array}$ & $\begin{array}{l}-0.010 \\
(0.007)\end{array}$ \\
\hline Education selection to Florida & $\begin{array}{c}0.064 \\
(0.104)\end{array}$ & $\begin{array}{c}0.175^{* * * *} \\
(0.056)\end{array}$ & $\begin{array}{c}0.193^{* *} \\
(0.088)\end{array}$ & $\begin{array}{c}0.035 \\
(0.083)\end{array}$ & $\begin{array}{l}-0.012 \\
(0.048)\end{array}$ & $\begin{array}{l}-0.018 \\
(0.018)\end{array}$ & $\begin{array}{c}0.069 * * \\
(0.030)\end{array}$ & $\begin{array}{c}-0.006^{*} \\
(0.003)\end{array}$ \\
\hline Observations & 140,071 & 49,526 & 140,057 & 49,314 & 30,474 & $1,108,495$ & 620,147 & 898,797 \\
\hline R-squared & 0.380 & 0.368 & 0.387 & 0.355 & 0.375 & 0.213 & 0.135 & 0.103 \\
\hline Year*school FE & YES & YES & YES & YES & YES & YES & YES & YES \\
\hline Grade FE & - & - & - & - & - & YES & YES & YES \\
\hline Individual controls & YES & YES & YES & YES & YES & YES & YES & YES \\
\hline Dependent Variable (mean) & 0.000 & 0.000 & 0.000 & 0.000 & 0.741 & 0.060 & 0.243 & 0.048 \\
\hline Dependent Variable (sd) & 1.000 & 0.782 & 1.000 & 0.826 & 0.438 & 0.077 & 0.429 & 0.214 \\
\hline Long-Term Orientation (mean) & 0.193 & 0.193 & 0.193 & 0.193 & 0.192 & 0.192 & 0.191 & 0.191 \\
\hline Long-Term Orientation (sd) & 0.116 & 0.115 & 0.116 & 0.116 & 0.111 & 0.113 & 0.111 & 0.112 \\
\hline Long-Term Orientation (beta) & 0.040 & 0.060 & 0.022 & 0.088 & 0.032 & -0.077 & 0.000 & 0.000 \\
\hline N_clust & 65 & 57 & 65 & 57 & 60 & 69 & 66 & 66 \\
\hline \multicolumn{9}{|l|}{ PANEL B } \\
\hline VARIABLES & $\begin{array}{c}\text { (1) } \\
\text { Math score, } \\
\text { 3rd grade }\end{array}$ & $\begin{array}{c}\text { (2) } \\
\text { Math score, } \\
\text { change } 3 \text { rd to } 8 \text { th }\end{array}$ & $\begin{array}{c}\text { (3) } \\
\text { Reading score, } \\
\text { 3rd grade }\end{array}$ & $\begin{array}{c}\text { (4) } \\
\text { Reading score, } \\
\text { change } 3 \text { rd to } 8 \text { th }\end{array}$ & $\begin{array}{c}\text { (5) } \\
\text { Graduation }\end{array}$ & $\begin{array}{c}(6) \\
\% \text { Absent } \\
\text { Days } \\
\end{array}$ & $\begin{array}{c}(7) \\
\text { Disciplinary } \\
\text { Incident } \\
\end{array}$ & $\begin{array}{c}\text { (8) } \\
\text { Retention }\end{array}$ \\
\hline Long-Term Orientation & $\begin{array}{c}0.303 \\
(0.184)\end{array}$ & $\begin{array}{c}0.343 * * \\
(0.129)\end{array}$ & $\begin{array}{c}0.181 \\
(0.182)\end{array}$ & $\begin{array}{c}0.443 * * \\
(0.168)\end{array}$ & $\begin{array}{c}0.072 \\
(0.064)\end{array}$ & $\begin{array}{l}-0.013 \\
(0.008)\end{array}$ & $\begin{array}{l}-0.006 \\
(0.022)\end{array}$ & $\begin{array}{c}-0.007 * \\
(0.004)\end{array}$ \\
\hline Log GDP pc year 2000 ppp & $\begin{array}{c}-0.077^{* *} \\
(0.033)\end{array}$ & $\begin{array}{c}-0.116^{* * * *} \\
(0.024)\end{array}$ & $\begin{array}{l}-0.011 \\
(0.022)\end{array}$ & $\begin{array}{c}-0.101 * * * \\
(0.025)\end{array}$ & $\begin{array}{c}0.012 \\
(0.011)\end{array}$ & $\begin{array}{c}0.008^{* * * *} \\
(0.001)\end{array}$ & $\begin{array}{c}0.023^{* * *} \\
(0.005)\end{array}$ & $\begin{array}{c}0.000 \\
(0.001)\end{array}$ \\
\hline Distance from the US (log) & $\begin{array}{l}-0.030 \\
(0.037)\end{array}$ & $\begin{array}{l}-0.010 \\
(0.023)\end{array}$ & $\begin{array}{l}-0.051 \\
(0.031)\end{array}$ & $\begin{array}{l}-0.012 \\
(0.025)\end{array}$ & $\begin{array}{c}0.006 \\
(0.013)\end{array}$ & $\begin{array}{l}-0.000 \\
(0.002)\end{array}$ & $\begin{array}{l}-0.007 \\
(0.005)\end{array}$ & $\begin{array}{l}-0.000 \\
(0.001)\end{array}$ \\
\hline Savings over GDP/100 & $\begin{array}{c}0.424 \\
(0.535)\end{array}$ & $\begin{array}{c}0.260 \\
(0.278)\end{array}$ & $\begin{array}{c}0.349 \\
(0.463)\end{array}$ & $\begin{array}{l}-0.333 \\
(0.432)\end{array}$ & $\begin{array}{c}0.096 \\
(0.168)\end{array}$ & $\begin{array}{c}-0.082^{* * *} \\
(0.015)\end{array}$ & $\begin{array}{c}-0.246 * * * \\
(0.079)\end{array}$ & $\begin{array}{c}0.023 * * \\
(0.011)\end{array}$ \\
\hline Education selection to Florida & $\begin{array}{c}0.319 * * * \\
(0.065)\end{array}$ & $\begin{array}{l}-0.048 \\
(0.094)\end{array}$ & $\begin{array}{c}0.407 * * * \\
(0.045)\end{array}$ & $\begin{array}{l}-0.007 \\
(0.098)\end{array}$ & $\begin{array}{l}0.082^{* *} \\
(0.032)\end{array}$ & $\begin{array}{c}0.008^{* * *} \\
(0.003)\end{array}$ & $\begin{array}{c}-0.032^{* * *} \\
(0.008)\end{array}$ & $\begin{array}{c}-0.015^{* * *} \\
(0.003)\end{array}$ \\
\hline Mean PISA score in Math & $\begin{array}{l}0.121^{*} \\
(0.064)\end{array}$ & $\begin{array}{c}0.050 \\
(0.042)\end{array}$ & $\begin{array}{l}0.100^{*} \\
(0.052)\end{array}$ & $\begin{array}{c}0.010 \\
(0.046)\end{array}$ & $\begin{array}{c}0.026 \\
(0.021)\end{array}$ & $\begin{array}{l}-0.001 \\
(0.002)\end{array}$ & $\begin{array}{c}-0.020^{* * *} \\
(0.006)\end{array}$ & $\begin{array}{c}-0.006^{* * * *} \\
(0.001)\end{array}$ \\
\hline Observations & 46,514 & 14,774 & 46,507 & 14,755 & 5,941 & 271,969 & 131,968 & 221,020 \\
\hline R-squared & 0.494 & 0.499 & 0.521 & 0.488 & 0.464 & 0.263 & 0.175 & 0.177 \\
\hline Year*school FE & YES & YES & YES & YES & YES & YES & YES & YES \\
\hline Grade FE & - & - & - & - & - & YES & YES & YES \\
\hline Individual controls & YES & YES & YES & YES & YES & YES & YES & YES \\
\hline Dependent Variable (mean) & 0.000 & 0.000 & 0.000 & 0.000 & 0.784 & 0.045 & 0.196 & 0.046 \\
\hline Dependent Variable (sd) & 1.000 & 0.756 & 1.000 & 0.792 & 0.412 & 0.065 & 0.397 & 0.209 \\
\hline Long-Term Orientation (mean) & 0.302 & 0.313 & 0.302 & 0.313 & 0.326 & 0.308 & 0.313 & 0.309 \\
\hline Long-Term Orientation (sd) & 0.124 & 0.134 & 0.124 & 0.134 & 0.143 & 0.130 & 0.134 & 0.131 \\
\hline Long-Term Orientation (beta) & 0.038 & 0.061 & 0.022 & 0.075 & 0.025 & -0.025 & -0.002 & -0.004 \\
\hline N_clust & 39 & 38 & 39 & 38 & 28 & 39 & 38 & 39 \\
\hline
\end{tabular}

Notes. The table replicates the results in Table 7 for the second generation immigrants, identified as those who were born in Florida and whose mothers were born abroad (see the text in this Appendix). The Table reports OLS estimates, with standard errors clustered at the country level. The unit of observation is a student born between 1992 and 2002 and observed during the academic years 2002-2012. The dependent variables are: students' Florida Comprehensive Assessment Test reading score in grade 3 (standardized with mean 0 and variance 1), the change in reading score from grade 3 to grade 8 , high school graduation (a dummy for whether the student received a standard diploma within four years after entering the $9^{\text {th }}$ grade for the first time), absence rates (the percentage of days in which the student is absent during the academic year) and retention (an indicator for whether the student repeats the same grade at least once) measured in grades 3-12, and disciplinary incidents (a dummy for whether the student was involved in a disciplinary incident defined as serious offences often leading to suspension) measured in grades 6-12. The regressions also include the same individual controls reported in Table A4 (coefficients not reported). The additional country-controls are described in this Appendix. Panel B specification includes in addition to the standard country controls, also a control for the mean PISA score in Math in the country of origin. The "Long Term Orientation" variable is based on Hofstede (2010) and is measured on a $0-1$ scale. We describe in details all the variables in this Appendix. ***, **, and * indicate significance at the $1 \%, 5 \%$, and $10 \%$ levels. 
Table A8

Long-Term Orientation and educational outcomes, Heterogeneous effects, second generation (extended definition)

\begin{tabular}{|c|c|c|c|c|c|c|c|c|}
\hline VARIABLES & $\begin{array}{c}\text { (1) } \\
\text { Math score, } \\
\text { 3rd grade } \\
\end{array}$ & $\begin{array}{c}\text { (2) } \\
\text { Math score, } \\
\text { change 3rd to 8th }\end{array}$ & $\begin{array}{c}\text { (3) } \\
\text { Reading score, } \\
\text { 3rd grade } \\
\end{array}$ & $\begin{array}{c}\text { (4) } \\
\text { Reading score, } \\
\text { change 3rd to 8th }\end{array}$ & $\begin{array}{c}\text { (5) } \\
\text { Graduation }\end{array}$ & $\begin{array}{c}(6) \\
\% \text { Absent } \\
\text { Days } \\
\end{array}$ & $\begin{array}{c}(7) \\
\text { Disciplinary } \\
\text { Incident } \\
\end{array}$ & $\begin{array}{c}(8) \\
\text { Retention }\end{array}$ \\
\hline Long-Term Orientation (LTO) & $\begin{array}{c}0.818^{* * *} \\
(0.202)\end{array}$ & $\begin{array}{c}0.448 * * * \\
(0.164)\end{array}$ & $\begin{array}{c}0.437 * * * \\
(0.111)\end{array}$ & $\begin{array}{c}0.353 * * \\
(0.173)\end{array}$ & $\begin{array}{l}-0.057 \\
(0.075)\end{array}$ & $\begin{array}{c}-0.035 * * \\
(0.018)\end{array}$ & $\begin{array}{c}-0.270^{* * *} \\
(0.099)\end{array}$ & $\begin{array}{c}-0.035 * * \\
(0.014)\end{array}$ \\
\hline Mother high school graduate*LTO & $\begin{array}{c}-0.209 * * \\
(0.087)\end{array}$ & $\begin{array}{l}-0.064 \\
(0.074)\end{array}$ & $\begin{array}{l}-0.027 \\
(0.064)\end{array}$ & $\begin{array}{l}-0.120 \\
(0.093)\end{array}$ & $\begin{array}{c}0.090 \\
(0.072)\end{array}$ & $\begin{array}{c}0.017 \\
(0.012)\end{array}$ & $\begin{array}{l}0.126^{* *} \\
(0.049)\end{array}$ & $\begin{array}{l}0.013 \\
(0.010)\end{array}$ \\
\hline Mother attended some college*LTO & $\begin{array}{c}-0.358^{* * *} \\
(0.093)\end{array}$ & $\begin{array}{c}-0.258^{* * *} \\
(0.093)\end{array}$ & $\begin{array}{l}-0.047 \\
(0.065)\end{array}$ & $\begin{array}{l}-0.190^{*} \\
(0.100)\end{array}$ & $\begin{array}{c}0.090 \\
(0.081)\end{array}$ & $\begin{array}{l}0.024 * \\
(0.014)\end{array}$ & $\begin{array}{c}0.170^{* * *} \\
(0.047)\end{array}$ & $\begin{array}{l}0.025^{* *} \\
(0.010)\end{array}$ \\
\hline Mother $4 \mathrm{yr}$ college graduate*LTO & $\begin{array}{c}-0.268 * * * \\
(0.099)\end{array}$ & $\begin{array}{l}-0.092 \\
(0.112)\end{array}$ & $\begin{array}{c}0.051 \\
(0.081)\end{array}$ & $\begin{array}{l}-0.176 \\
(0.134)\end{array}$ & $\begin{array}{l}-0.000 \\
(0.054)\end{array}$ & $\begin{array}{l}0.031 \text { ** } \\
(0.014)\end{array}$ & $\begin{array}{c}0.202^{* * *} \\
(0.044)\end{array}$ & $\begin{array}{c}0.024^{* * *} \\
(0.009)\end{array}$ \\
\hline Mother teen pregnancy*LTO & $\begin{array}{c}-0.679^{* *} \\
(0.341)\end{array}$ & $\begin{array}{l}-0.025 \\
(0.488)\end{array}$ & $\begin{array}{c}-0.877 \text { *** } \\
(0.277)\end{array}$ & $\begin{array}{l}-0.199 \\
(0.373)\end{array}$ & $\begin{array}{l}-0.356 \\
(0.495)\end{array}$ & $\begin{array}{c}0.030 \\
(0.021)\end{array}$ & $\begin{array}{c}0.202 \\
(0.162)\end{array}$ & $\begin{array}{c}0.138^{* * *} \\
(0.041)\end{array}$ \\
\hline Mother married at time of birth*LTO & $\begin{array}{l}0.145^{*} \\
(0.081)\end{array}$ & $\begin{array}{c}0.103 \\
(0.095)\end{array}$ & $\begin{array}{c}0.002 \\
(0.063)\end{array}$ & $\begin{array}{c}0.274 * * * \\
(0.089)\end{array}$ & $\begin{array}{c}0.133 \\
(0.106)\end{array}$ & $\begin{array}{c}0.001 \\
(0.005)\end{array}$ & $\begin{array}{l}-0.007 \\
(0.032)\end{array}$ & $\begin{array}{l}0.001 \\
(0.006)\end{array}$ \\
\hline Number of older siblings*LTO & $\begin{array}{l}-0.020 \\
(0.023)\end{array}$ & $\begin{array}{l}-0.046 \\
(0.032)\end{array}$ & $\begin{array}{l}-0.024 \\
(0.032)\end{array}$ & $\begin{array}{l}-0.051 \\
(0.033)\end{array}$ & $\begin{array}{c}0.008 \\
(0.013)\end{array}$ & $\begin{array}{c}0.001 \\
(0.003)\end{array}$ & $\begin{array}{l}-0.019 \\
(0.013)\end{array}$ & $\begin{array}{l}-0.002 \\
(0.003)\end{array}$ \\
\hline Median income in zipcode of birth $(100,000$ of $\$) *$ LTO & $\begin{array}{l}-0.022 \\
(0.204)\end{array}$ & $\begin{array}{c}0.224 \\
(0.144)\end{array}$ & $\begin{array}{c}0.042 \\
(0.144)\end{array}$ & $\begin{array}{l}-0.001 \\
(0.174)\end{array}$ & $\begin{array}{c}-0.212^{* *} \\
(0.098)\end{array}$ & $\begin{array}{l}-0.008 \\
(0.013)\end{array}$ & $\begin{array}{c}0.083 \\
(0.078)\end{array}$ & $\begin{array}{c}0.012 \\
(0.010)\end{array}$ \\
\hline Free or Reduced Priced Lunch*LTO & $\begin{array}{c}0.039 \\
(0.073)\end{array}$ & $\begin{array}{c}-0.109 * \\
(0.058)\end{array}$ & $\begin{array}{c}0.048 \\
(0.066)\end{array}$ & $\begin{array}{l}-0.066 \\
(0.068)\end{array}$ & $\begin{array}{c}0.021 \\
(0.038)\end{array}$ & $\begin{array}{l}-0.005 \\
(0.007)\end{array}$ & $\begin{array}{c}-0.051^{* *} \\
(0.021)\end{array}$ & $\begin{array}{l}-0.005 \\
(0.003)\end{array}$ \\
\hline Mother high school graduate & $\begin{array}{c}0.122 * * * \\
(0.027)\end{array}$ & $\begin{array}{l}0.033^{*} \\
(0.019)\end{array}$ & $\begin{array}{c}0.094 * * * \\
(0.028)\end{array}$ & $\begin{array}{l}0.055^{*} \\
(0.030)\end{array}$ & $\begin{array}{l}-0.005 \\
(0.015)\end{array}$ & $\begin{array}{l}-0.005 \\
(0.003)\end{array}$ & $\begin{array}{c}-0.044 * * * \\
(0.010)\end{array}$ & $\begin{array}{c}-0.011^{* * *} \\
(0.004)\end{array}$ \\
\hline Mother attended some college & $\begin{array}{c}0.240^{* * *} \\
(0.020)\end{array}$ & $\begin{array}{c}0.103 * * * \\
(0.025)\end{array}$ & $\begin{array}{c}0.187 * * * \\
(0.022)\end{array}$ & $\begin{array}{c}0.105^{* * *} \\
(0.028)\end{array}$ & $\begin{array}{l}-0.000 \\
(0.028)\end{array}$ & $\begin{array}{l}-0.006 \\
(0.004)\end{array}$ & $\begin{array}{c}-0.061 * * * \\
(0.009)\end{array}$ & $\begin{array}{c}-0.018 * * * \\
(0.004)\end{array}$ \\
\hline Mother $4 \mathrm{yr}$ college graduate & $\begin{array}{c}0.390 * * * \\
(0.017)\end{array}$ & $\begin{array}{c}0.169 * * * \\
(0.025)\end{array}$ & $\begin{array}{c}0.304 * * * \\
(0.022)\end{array}$ & $\begin{array}{c}0.210^{* * *} \\
(0.032)\end{array}$ & $\begin{array}{c}0.053^{* * *} \\
(0.010)\end{array}$ & $\begin{array}{c}-0.012^{* * *} \\
(0.004)\end{array}$ & $\begin{array}{c}-0.094^{* * *} \\
(0.008)\end{array}$ & $\begin{array}{c}-0.022^{* * *} \\
(0.002)\end{array}$ \\
\hline Mother teen pregnancy & $\begin{array}{c}0.048 \\
(0.057)\end{array}$ & $\begin{array}{c}0.008 \\
(0.088)\end{array}$ & $\begin{array}{c}0.128^{* * *} \\
(0.041)\end{array}$ & $\begin{array}{l}-0.021 \\
(0.065)\end{array}$ & $\begin{array}{c}0.102 \\
(0.067)\end{array}$ & $\begin{array}{c}0.006 \\
(0.005)\end{array}$ & $\begin{array}{c}0.013 \\
(0.031)\end{array}$ & $\begin{array}{c}-0.019 * * * \\
(0.007)\end{array}$ \\
\hline Mother married at time of birth & $\begin{array}{c}0.074 * * * \\
(0.014)\end{array}$ & $\begin{array}{l}0.037 * * \\
(0.018)\end{array}$ & $\begin{array}{c}0.084 * * * \\
(0.012)\end{array}$ & $\begin{array}{l}-0.003 \\
(0.020)\end{array}$ & $\begin{array}{c}0.012 \\
(0.023)\end{array}$ & $\begin{array}{c}-0.007^{* * *} \\
(0.001)\end{array}$ & $\begin{array}{c}-0.055^{* * *} \\
(0.006)\end{array}$ & $\begin{array}{c}-0.008 * * * \\
(0.001)\end{array}$ \\
\hline Number of older siblings & $\begin{array}{c}-0.024^{* * *} * \\
(0.007)\end{array}$ & $\begin{array}{l}-0.004 \\
(0.008)\end{array}$ & $\begin{array}{c}-0.035^{* * *} \\
(0.011)\end{array}$ & $\begin{array}{c}0.002 \\
(0.008)\end{array}$ & $\begin{array}{c}-0.007^{* *} \\
(0.003)\end{array}$ & $\begin{array}{c}0.003^{* * *} \\
(0.001)\end{array}$ & $\begin{array}{c}0.024^{* * *} \\
(0.002)\end{array}$ & $\begin{array}{c}0.004^{* * *} \\
(0.001)\end{array}$ \\
\hline Median income in zipcode of birth $(100,000$ of $\$)$ & $\begin{array}{c}0.177^{* * *} \\
(0.048)\end{array}$ & $\begin{array}{l}-0.049 \\
(0.048)\end{array}$ & $\begin{array}{c}0.134^{* * *} \\
(0.029)\end{array}$ & $\begin{array}{c}0.043 \\
(0.038)\end{array}$ & $\begin{array}{c}0.113^{* * *} \\
(0.031)\end{array}$ & $\begin{array}{c}0.006 \\
(0.005)\end{array}$ & $\begin{array}{l}-0.057^{*} \\
(0.029)\end{array}$ & $\begin{array}{c}-0.013^{* * * *} \\
(0.004)\end{array}$ \\
\hline Free or Reduced Priced Lunch & $\begin{array}{c}-0.163^{* * *} \\
(0.014)\end{array}$ & $\begin{array}{l}-0.012 \\
(0.013)\end{array}$ & $\begin{array}{c}-0.174^{* * *} \\
(0.014)\end{array}$ & $\begin{array}{c}-0.050^{* * *} \\
(0.015)\end{array}$ & $\begin{array}{c}-0.022^{*} \\
(0.012)\end{array}$ & $\begin{array}{c}0.001 \\
(0.003)\end{array}$ & $\begin{array}{c}0.049 * * * \\
(0.004)\end{array}$ & $\begin{array}{c}0.007^{* * *} \\
(0.001)\end{array}$ \\
\hline Observations & 184,331 & 62,005 & 184,309 & 61,668 & 6,623 & 960,054 & 425,110 & 762,581 \\
\hline R-squared & 0.369 & 0.334 & 0.379 & 0.319 & 0.325 & 0.183 & 0.151 & 0.121 \\
\hline Year*school FE & YES & YES & YES & YES & YES & YES & YES & YES \\
\hline Grade FE & - & - & - & - & - & YES & YES & YES \\
\hline Individual controls & YES & YES & YES & YES & YES & YES & YES & YES \\
\hline Dependent Variable (mean) & 0.000 & 0.000 & 0.000 & 0.000 & 0.874 & 0.045 & 0.208 & 0.042 \\
\hline Dependent Variable (sd) & 1.000 & 0.778 & 1.000 & 0.809 & 0.332 & 0.057 & 0.406 & 0.200 \\
\hline Long-Term Orientation (mean) & 0.207 & 0.209 & 0.207 & 0.210 & 0.214 & 0.206 & 0.206 & 0.206 \\
\hline Long-Term Orientation (sd) & 0.143 & 0.149 & 0.143 & 0.149 & 0.158 & 0.144 & 0.146 & 0.144 \\
\hline Long-Term Orientation (beta) & 0.117 & 0.086 & 0.062 & 0.065 & -0.027 & -0.088 & -0.097 & -0.025 \\
\hline N_clust & 90 & 79 & 90 & 79 & 58 & 90 & 82 & 90 \\
\hline
\end{tabular}


Table A9

Futureless language (Chen) and educational outcomes, robustness to the exclusion of Spanish

\begin{tabular}{|c|c|c|c|c|c|c|c|c|}
\hline & \multicolumn{8}{|c|}{ PANEL A: 1st generation + 2nd generation (extended definition), exclusion of Spanish speakers } \\
\hline VARIABLES & $\begin{array}{c}1) \\
\text { Math score, } \\
\text { 3rd grade }\end{array}$ & $\begin{array}{c}\text { (2) } \\
\text { Math score, } \\
\text { change 3rd to 8th }\end{array}$ & $\begin{array}{c}\text { (3) } \\
\text { Reading score, } \\
\text { 3rd grade }\end{array}$ & $\begin{array}{c}\text { (4) } \\
\text { Reading score, } \\
\text { change } 3 \text { rd to } 8 \text { th }\end{array}$ & $\begin{array}{c}\text { (5) } \\
\text { Graduation }\end{array}$ & $\begin{array}{c}(6) \\
\% \text { Absent Days }\end{array}$ & $\begin{array}{c}(7) \\
\text { Disciplinary } \\
\text { Incident }\end{array}$ & $\begin{array}{c}\text { (8) } \\
\text { Retention }\end{array}$ \\
\hline Futureless Language (Chen) & $\begin{array}{c}0.302 * * * \\
(0.107)\end{array}$ & $\begin{array}{c}0.216^{* *} \\
(0.093)\end{array}$ & $\begin{array}{c}0.172 * * * \\
(0.053)\end{array}$ & $\begin{array}{c}0.182 * * \\
(0.085)\end{array}$ & $\begin{array}{c}0.028 * * \\
(0.011)\end{array}$ & $\begin{array}{c}-0.012 * * \\
(0.006)\end{array}$ & $\begin{array}{c}-0.047 * * \\
(0.022)\end{array}$ & $\begin{array}{c}-0.003^{* *} \\
(0.001)\end{array}$ \\
\hline Observations & 67,788 & 26,033 & 67,757 & 25,964 & 18,646 & 581,789 & 343,900 & 465,393 \\
\hline R-squared & 0.405 & 0.422 & 0.417 & 0.420 & 0.353 & 0.168 & 0.119 & 0.114 \\
\hline Year*school FE & YES & YES & YES & YES & YES & YES & YES & YES \\
\hline Grade FE & - & - & - & - & - & YES & YES & YES \\
\hline Individual controls & YES & YES & YES & YES & YES & YES & YES & YES \\
\hline Dependent Variable (mean) & 0.000 & 0.000 & 0.000 & 0.000 & 0.877 & 0.042 & 0.133 & 0.023 \\
\hline Dependent Variable (sd) & 1.000 & 0.766 & 1.000 & 0.844 & 0.328 & 0.064 & 0.339 & 0.149 \\
\hline Futureless Language (mean) & 0.108 & 0.110 & 0.108 & 0.109 & 0.093 & 0.102 & 0.100 & 0.101 \\
\hline Futureless Language (sd) & 0.310 & 0.312 & 0.310 & 0.312 & 0.291 & 0.303 & 0.300 & 0.301 \\
\hline Futureless Language (beta) & 0.094 & 0.088 & 0.053 & 0.067 & 0.025 & -0.055 & -0.042 & -0.006 \\
\hline N_clust & 80 & 73 & 80 & 73 & 70 & 85 & 83 & 84 \\
\hline \multicolumn{9}{|c|}{ PANEL B: 1 st generation, exclusion of Spanish speakers } \\
\hline VARIABLES & $\begin{array}{c}1) \\
\text { Math score, } \\
\text { 3rd grade } \\
\end{array}$ & $\begin{array}{c}\text { (2) } \\
\text { Math score, } \\
\text { change 3rd to 8th }\end{array}$ & $\begin{array}{c}\text { (3) } \\
\text { Reading score, } \\
\text { 3rd grade } \\
\end{array}$ & $\begin{array}{c}\text { (4) } \\
\text { Reading score, } \\
\text { change } 3 \text { rd to } 8 \text { th }\end{array}$ & $\begin{array}{c}(5) \\
\text { Graduation }\end{array}$ & $\begin{array}{c}(6) \\
\% \text { Absent Days }\end{array}$ & $\begin{array}{c}(7) \\
\text { Disciplinary } \\
\text { Incident } \\
\end{array}$ & $\begin{array}{c}(8) \\
\text { Retention }\end{array}$ \\
\hline Futureless Language (Chen) & $\begin{array}{c}0.305^{* * *} \\
(0.050)\end{array}$ & $\begin{array}{c}0.237 * * \\
(0.104)\end{array}$ & $\begin{array}{c}0.110^{* * *} \\
(0.038)\end{array}$ & $\begin{array}{l}0.161 * * \\
(0.069)\end{array}$ & $\begin{array}{c}0.004 \\
(0.018)\end{array}$ & $\begin{array}{r}-0.005 * \\
(0.003)\end{array}$ & $\begin{array}{c}-0.037 * * * \\
(0.007)\end{array}$ & $\begin{array}{c}-0.003 * \\
(0.001)\end{array}$ \\
\hline Observations & 30,274 & 11,985 & 30,261 & 11,947 & 11,392 & 321,798 & 204,298 & 253,240 \\
\hline R-squared & 0.529 & 0.566 & 0.536 & 0.565 & 0.400 & 0.213 & 0.145 & 0.150 \\
\hline Year*school FE & YES & YES & YES & YES & YES & YES & YES & YES \\
\hline Country FE & YES & YES & YES & YES & YES & YES & YES & YES \\
\hline Grade FE & - & - & - & - & - & YES & YES & YES \\
\hline Individual controls & YES & YES & YES & YES & YES & YES & YES & YES \\
\hline Dependent Variable (mean) & 0.000 & 0.000 & 0.000 & 0.000 & 0.867 & 0.045 & 0.133 & 0.024 \\
\hline Dependent Variable (sd) & 1.000 & 0.782 & 1.000 & 0.862 & 0.339 & 0.067 & 0.340 & 0.155 \\
\hline Futureless Language (mean) & 0.067 & 0.063 & 0.067 & 0.063 & 0.066 & 0.072 & 0.073 & 0.068 \\
\hline Futureless Language (sd) & 0.250 & 0.244 & 0.250 & 0.243 & 0.248 & 0.258 & 0.260 & 0.252 \\
\hline Futureless Language (beta) & 0.076 & 0.074 & 0.027 & 0.045 & 0.003 & -0.020 & -0.028 & -0.005 \\
\hline N_clust & 77 & 70 & 77 & 70 & 68 & 84 & 81 & 82 \\
\hline
\end{tabular}

Notes. The table repeats the same analysis as Table 13, Panel A and B in the text excluding students speaking Spanish. The unit of observation is a student born between 1992 and 2002 and observed during the academic years 2002-2012. In Panel A, the sample pools together first generation immigrants defined using the information on both the country of origin and the language spoken at home and the extended version of second generation immigrants defined using the information on the country of origin of the mother when available (Canada) or the language spoken at home for individuals whose mother was born either in the US or abroad (when the country of origin of the mother is not available). See details in the text and this Appendix for how the matching between languages and countries has been implemented. Panel B includes only first generation immigrants. The dependent variables are: students' Florida Comprehensive Assessment Test math score in grade 3 (standardized with mean 0 and variance 1), the change in math score from grade 3 to grade 8 , reading score in grade 3 (standardized with mean 0 and variance 1), change in reading score from grade 3 to grade 8 , high school graduation (a dummy for whether the student received a standard diploma within four years after entering the $9^{\text {th }}$ grade for the first time), absence rates (the percentage of days in which the student is absent during the academic year), disciplinary incidents (a dummy for whether the student was involved in a disciplinary incident, defined as serious offences often leading to suspension), and retention (an indicator for whether the student repeats the same grade at least once). The regressions also include the same individual controls reported in Table A4 (coefficients not reported). Futureless language is a dummy variable equal to 1 for "futureless" languages (languages that do not require "obligatory future time reference use in prediction-based contexts") from Chen (2013). We describe in details all the variables in this Appendix. ***, **, and * indicate significance at the $1 \%, 5 \%$, and $10 \%$ levels. 


\section{Table A10}

List of countries of origin, PISA, first and second generation (mother side and father side)

\begin{tabular}{|c|c|c|c|c|c|c|c|}
\hline COUNTRY & $\begin{array}{c}\text { 1st } \\
\text { generation }\end{array}$ & $\begin{array}{c}\text { 2nd } \\
\text { generation } \\
\text { (mother) }\end{array}$ & $\begin{array}{c}\text { 2nd } \\
\text { generation } \\
\text { (father) }\end{array}$ & COUNTRY & $\begin{array}{c}\text { 1st } \\
\text { generation }\end{array}$ & $\begin{array}{c}\text { 2nd } \\
\text { generation } \\
\text { (mother) }\end{array}$ & $\begin{array}{c}\text { 2nd } \\
\text { generation } \\
\text { (father) }\end{array}$ \\
\hline Albania & 1,187 & 375 & 347 & Macedonia & 40 & 37 & 35 \\
\hline Argentina & 217 & 93 & 85 & Malaysia & 119 & 71 & 61 \\
\hline Australia & 368 & 189 & 151 & Montenegro & 17 & 88 & 79 \\
\hline Austria & 71 & 273 & 198 & Morocco & 15 & 190 & 206 \\
\hline Bangladesh & 7 & 13 & 11 & Netherlands & 306 & 262 & 308 \\
\hline Belarus & 42 & 554 & 509 & New Zealand & 776 & 938 & 945 \\
\hline Belgium & 155 & 307 & 271 & Nigeria & 4 & 0 & 2 \\
\hline Bosnia and Herzegovina & 804 & 2,331 & 2,063 & Pakistan & 76 & 236 & 266 \\
\hline Brazil & 331 & 225 & 207 & Philippines & 339 & 518 & 213 \\
\hline Bulgaria & 9 & 36 & 20 & Poland & 159 & 359 & 279 \\
\hline Canada & 5 & 2 & 2 & Portugal & 1,722 & 3,034 & 2,866 \\
\hline Chile & 19 & 77 & 61 & Republic of Korea & 293 & 48 & 49 \\
\hline China & 6,987 & 15,456 & 14,637 & Romania & 58 & 69 & 75 \\
\hline Colombia & 9 & 6 & 7 & Russian Federation & 893 & 1,556 & 1,604 \\
\hline Croatia & 147 & 254 & 212 & Saudi Arabia & 0 & 0 & 1 \\
\hline Czech Republic & 80 & 223 & 195 & Serbia & 804 & 1,002 & 611 \\
\hline Denmark & 37 & 84 & 113 & Singapore & 16 & 9 & 10 \\
\hline Egypt & 952 & 769 & 715 & Slovakia & 172 & 582 & 690 \\
\hline Estonia & 136 & 88 & 59 & Slovenia & 13 & 15 & 18 \\
\hline France & 1,079 & 1,364 & 1,171 & South Africa & 418 & 114 & 116 \\
\hline Georgia & 1 & 0 & 0 & Spain & 85 & 376 & 466 \\
\hline Germany & 1,363 & 1,384 & 1,147 & Sweden & 276 & 396 & 307 \\
\hline Great Britain & 2,686 & 4,330 & 4,396 & Switzerland & 172 & 116 & 99 \\
\hline Greece & 25 & 101 & 165 & Taiwan & 22 & 28 & 11 \\
\hline Hong Kong-China & 378 & 255 & 475 & Tanzania & 0 & 1 & 0 \\
\hline Hungary & 17 & 20 & 18 & Thailand & 37 & 15 & 2 \\
\hline India & 281 & 240 & 247 & Turkey & 589 & 3,194 & 3,497 \\
\hline Iran (Islamic Republic of) & 8 & 7 & 12 & Ukraine & 133 & 566 & 607 \\
\hline Iraq & 213 & 128 & 178 & United States & 1,409 & 489 & 636 \\
\hline Italy & 383 & 1,754 & 3,029 & Uruguay & 16 & 97 & 85 \\
\hline Japan & 2 & 2 & 0 & Viet Nam & 76 & 351 & 346 \\
\hline Jordan & 592 & 187 & 149 & Zambia & 1 & 0 & 0 \\
\hline \multirow[t]{2}{*}{ Lithuania } & 2 & 0 & 0 & & & & \\
\hline & & & & Total & 27,649 & 45,884 & 45,340 \\
\hline
\end{tabular}

Notes. The table reports the number of observations by country of origin for both first and second generation immigrants in the PISA sample. The observations for second generation students are calculated based both on mothers' or fathers' countries of origin. See the text of this Appendix for details. 
Table A11

Number of first and second generation immigrants, by country of destination, PISA

\begin{tabular}{|c|c|c|c|c|c|c|c|}
\hline COUNTRY & $\begin{array}{c}1 \text { st } \\
\text { generation }\end{array}$ & $\begin{array}{c}\text { 2nd } \\
\text { generation } \\
\text { (mother) }\end{array}$ & $\begin{array}{c}\text { 2nd } \\
\text { generation } \\
\text { (father) }\end{array}$ & COUNTRY & $\begin{array}{c}1 \text { st } \\
\text { generation }\end{array}$ & $\begin{array}{c}\text { 2nd } \\
\text { generation } \\
\text { (mother) }\end{array}$ & $\begin{array}{c}\text { 2nd } \\
\text { generation } \\
\text { (father) }\end{array}$ \\
\hline Argentina & 68 & 235 & 192 & Latvia & 242 & 2,032 & 2,200 \\
\hline Australia & 3,070 & 5,411 & 5,453 & Liechtenstein & 239 & 279 & 247 \\
\hline Austria & 773 & 1,340 & 1,310 & Luxembourg & 1,906 & 3,357 & 3,463 \\
\hline Belgium & 1,375 & 1,221 & 1,256 & Mauritius & 3 & 19 & 12 \\
\hline China & 2,971 & 10,082 & 9,466 & Mexico & 1,162 & 253 & 400 \\
\hline Costa Rica & 9 & 6 & 7 & Moldova & 80 & 192 & 178 \\
\hline Croatia & 633 & 1,698 & 1,616 & Montenegro & 956 & 1,421 & 779 \\
\hline Czech Republic & 269 & 684 & 800 & Netherlands & 160 & 542 & 590 \\
\hline Denmark & 233 & 962 & 1,033 & New Zealand & 1,567 & 951 & 1,012 \\
\hline Finland & 688 & 614 & 469 & Norway & 133 & 231 & 228 \\
\hline Germany & 277 & 1,173 & 1,244 & Portugal & 190 & 64 & 65 \\
\hline Great Britain & 385 & 496 & 458 & Qatar & 1,544 & 956 & 863 \\
\hline Greece & 770 & 207 & 178 & Serbia & 13 & 84 & 75 \\
\hline Hong Kong-China & 3,773 & 5,063 & 5,162 & Slovak Republic & 74 & 213 & 185 \\
\hline Indonesia & 72 & 18 & 19 & Slovenia & 12 & 11 & 16 \\
\hline Ireland & 1,080 & 850 & 699 & Switzerland & 1,937 & 4,426 & 4,988 \\
\hline Israel & 487 & 351 & 316 & Turkey & 74 & 111 & 61 \\
\hline Korea & 7 & 16 & 1 & Uruguay & 330 & 193 & 181 \\
\hline \multirow[t]{2}{*}{ Kyrgyzstan } & 87 & 122 & 118 & & & & \\
\hline & & & & Total & 27,649 & 45,884 & 45,340 \\
\hline
\end{tabular}

Notes. The table reports the number of observations of immigrants students (first and second generation) by country of destinations in the PISA sample. The observations for second generations students are calculated based both on mothers' or fathers' countries of origin. 


\section{Table A12}

\section{Long-Term Orientation and educational outcomes, PISA Second generation immigrants (paternal side)}

\begin{tabular}{|c|c|c|c|c|c|c|c|c|c|c|}
\hline & (1) & (2) & (3) & (4) & (5) & (6) & (7) & (8) & (9) & (10) \\
\hline VARIABLES & Math & Reading & Science & Retention & Truancy & Math & Reading & Science & Retention & Truancy \\
\hline Long-Term Orientation & $\begin{array}{c}0.697 * * * \\
(0.205)\end{array}$ & $\begin{array}{c}0.669^{* * *} \\
(0.188)\end{array}$ & $\begin{array}{c}0.767^{* * *} \\
(0.204)\end{array}$ & $\begin{array}{c}-0.080 * * * \\
(0.021)\end{array}$ & $\begin{array}{c}-0.073^{* *} \\
(0.031)\end{array}$ & $\begin{array}{c}0.747^{* * *} \\
(0.211)\end{array}$ & $\begin{array}{c}0.708^{* * *} \\
(0.198)\end{array}$ & $\begin{array}{c}0.823^{* * *} \\
(0.213)\end{array}$ & $\begin{array}{c}-0.086^{* * *} \\
(0.019)\end{array}$ & $\begin{array}{c}-0.074 * * \\
(0.031)\end{array}$ \\
\hline Male & $\begin{array}{c}0.188^{* * *} \\
(0.016)\end{array}$ & $\begin{array}{c}-0.327^{* * *} \\
(0.035)\end{array}$ & $\begin{array}{c}0.076^{* * *} \\
(0.019)\end{array}$ & $\begin{array}{c}0.011^{*} \\
(0.006)\end{array}$ & $\begin{array}{l}-0.010 \\
(0.008)\end{array}$ & $\begin{array}{c}0.196^{* * *} \\
(0.015)\end{array}$ & $\begin{array}{c}-0.324 * * * \\
(0.033)\end{array}$ & $\begin{array}{c}0.078^{* * *} \\
(0.019)\end{array}$ & $\begin{array}{c}0.009 \\
(0.006)\end{array}$ & $\begin{array}{l}-0.010 \\
(0.008)\end{array}$ \\
\hline Age of student & $\begin{array}{c}-0.213^{* * *} \\
(0.032)\end{array}$ & $\begin{array}{c}-0.199 * * * \\
(0.033)\end{array}$ & $\begin{array}{c}-0.181 \text { *** } \\
(0.034)\end{array}$ & $\begin{array}{c}0.271 \text { *** } \\
(0.035)\end{array}$ & $\begin{array}{c}0.046^{* * *} \\
(0.012)\end{array}$ & $\begin{array}{c}-0.222^{* * *} \\
(0.035)\end{array}$ & $\begin{array}{c}-0.205^{* * *} \\
(0.038)\end{array}$ & $\begin{array}{c}-0.187^{* * *} \\
(0.040)\end{array}$ & $\begin{array}{c}0.291 * * * \\
(0.034)\end{array}$ & $\begin{array}{c}0.047^{* * *} \\
(0.012)\end{array}$ \\
\hline Wealth & & & & & & $\begin{array}{l}-0.002 \\
(0.012)\end{array}$ & $\begin{array}{l}-0.018^{*} \\
(0.009)\end{array}$ & $\begin{array}{c}-0.025^{* *} \\
(0.010)\end{array}$ & $\begin{array}{c}0.005 \\
(0.004)\end{array}$ & $\begin{array}{c}0.004 \\
(0.003)\end{array}$ \\
\hline Observations & 45,340 & 45,340 & 45,340 & 29,735 & 13,346 & 38,033 & 38,033 & 38,033 & 23,448 & 13,314 \\
\hline $\mathrm{R}$-squared & 0.365 & 0.338 & 0.342 & 0.478 & 0.104 & 0.378 & 0.347 & 0.352 & 0.490 & 0.104 \\
\hline Year FE & YES & YES & YES & YES & YES & YES & YES & YES & YES & YES \\
\hline Grade FE & YES & YES & YES & YES & YES & YES & YES & YES & YES & YES \\
\hline Parents' education FE & YES & YES & YES & YES & YES & YES & YES & YES & YES & YES \\
\hline Country of destination FE & YES & YES & YES & YES & YES & YES & YES & YES & YES & YES \\
\hline Dependent Variable (mean) & 0.000 & 0.000 & 0.000 & 0.143 & 0.120 & 0.000 & 0.000 & 0.000 & 0.156 & 0.120 \\
\hline Dependent Variable (sd) & 1.000 & 1.000 & 1.000 & 0.350 & 0.325 & 1.000 & 1.000 & 1.000 & 0.363 & 0.324 \\
\hline Long-Term Orientation (mean) & 0.643 & 0.643 & 0.643 & 0.639 & 0.617 & 0.642 & 0.642 & 0.642 & 0.634 & 0.617 \\
\hline Long-Term Orientation (sd) & 0.223 & 0.223 & 0.223 & 0.224 & 0.230 & 0.228 & 0.228 & 0.228 & 0.231 & 0.230 \\
\hline Long-Term Orientation (beta) & 0.156 & 0.149 & 0.171 & -0.051 & -0.052 & 0.170 & 0.161 & 0.187 & -0.055 & -0.052 \\
\hline N_clust & 60 & 60 & 60 & 57 & 55 & 57 & 57 & 57 & 53 & 55 \\
\hline
\end{tabular}

Notes. The table reports OLS estimates, with standard errors clustered at the country of origin level. The unit of observation is a second generation immigrant student on the paternal side from one of the 63 countries residing in one of the 37 countries surveyed in PISA for which information about the country of origin of the parents is available (4 waves from 2003 to 2012 depending on whether the variables used in the regression are all available - details are on the online Appendix). The dependent variables are Math, Reading, Science scores calculated according to the description on the online appendix, retention (a dummy variable equal to 1 if a student repeated at least one year during his/her school career), and truancy (a dummy variable equal to 1 if the student skipped at least one full day of school in the previous two weeks). The "Long Term Orientation" variable is based on Hofstede (2010) and is measured on a 0-1 scale. Individual controls are: male (a dummy equal to one if the student is a boy), age (the age of the student expressed in years), dummies for student grade and for parents' education, wealth (an index of family wealth possessions built by OECD - PISA). We describe in details all the variables (and their availability in different PISA waves) on the online Appendix. ***, **, and $*$ indicate significance at the $1 \%, 5 \%$, and $10 \%$ levels.

\section{References}

Chen, Keith M. (2013), “The Effect of Language on Economic Behavior: Evidence from Savings Rates, Health Behaviors, and Retirement Assets," American Economic Review, 103(2): 690-731.

Feliciano, Cynthia (2005), "Does Selective Migration Matter? Explaining Ethnic Disparities in Educational Attainment among Immigrants' Children," The International Migration Review, Vol. 39, No. 4, pp. 841-871. 
Galor, Oded and Omer Ozak (2016), “The Agricultural Origins of Time Preference,” American Economic Review, forthcoming.

Lieberson, S. (1976), "Rank-sum Comparisons between Groups”, Sociological Methodology, 7: 276-291. 